\title{
Myofibroblast differentiation in hypoxia: \\ a novel role for ArhGAP29
}

\section{Doctoral Thesis}

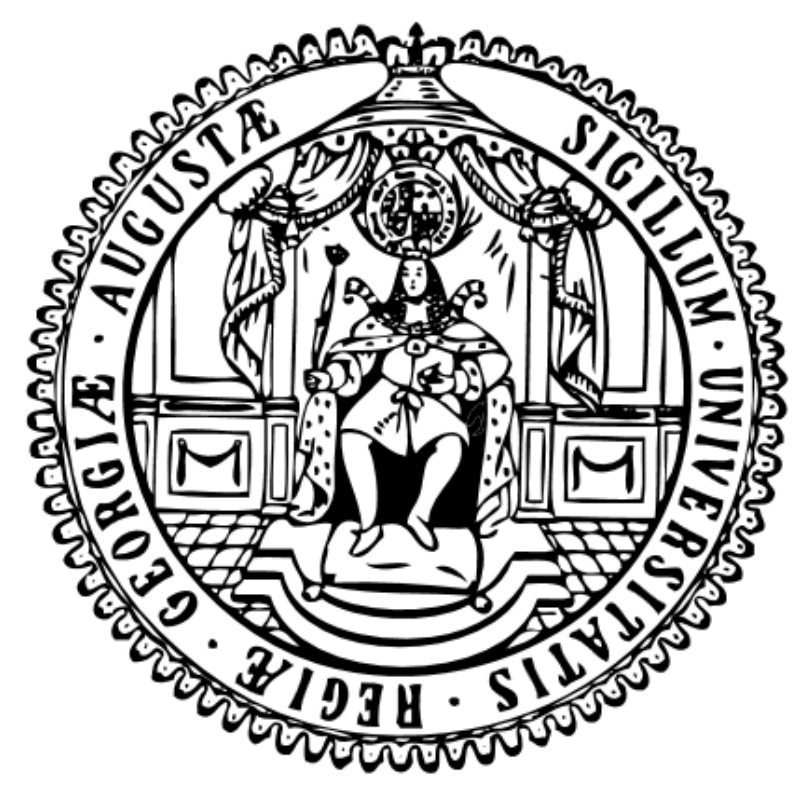

In partial fulfillment of the requirements for the degree "Doctor rerum naturalium (Dr. rer. nat.)"

within the Molecular Medicine Study Programme of the Georg-August University School of Science (GAUSS) at the Georg-August University Göttingen

submitted by

Lisa Leinhos

born in Friedberg (Hesse), Germany

Göttingen, 2019 


\section{Thesis Committee}

Prof. Dr. Dörthe M. Katschinski (supervisor)

Institute of Cardiovascular Physiology

University Medical Centre, Georg-August University Göttingen

Humboldtallee 23, 37073 Göttingen

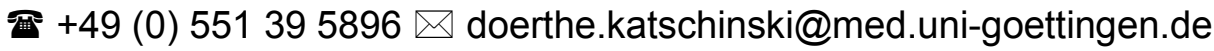

\section{Prof. Dr. Susanne Lutz}

Institute of Pharmacology and Toxicology

University Medical Centre, Georg-August University Göttingen

Robert-Koch-Straße 40, 37075 Göttingen

胥 +49 (0) $5513910665 \square$ susanne.lutz@med.uni-goettingen.de

\section{Prof. Dr. Ralph Kehlenbach}

Institute of Molecular Biology

University Medical Centre, Georg-August University Göttingen

Humboldtallee 23, 37073 Göttingen

용 49 (0) $551395950 \bowtie$ rkehlen@gwdg.de 


\title{
Extended Thesis Committee (Examination Board)
}

\author{
Prof. Dr. Frauke Alves
}

Institute of Diagnostic and Interventional Radiology

University Medical Centre, Georg-August University Göttingen

Robert-Koch-Straße 40, 37075 Göttingen

and

Translational Molecular Imaging

Max Planck Institute for Experimental Medicine

Hermann-Rein-Straße 3, 37075 Göttingen

용 +49 (0) $5513966991 \bowtie$ frauke.alves@med.uni-goettingen.de

\section{Prof. Dr. Ralf Dressel}

Institute for Cellular and Molecular Immunology

University Medical Centre, Georg-August University Göttingen

Humboldtallee 34, 37073 Göttingen

嘼+49 (0) $551395884 \square$ rdresse@gwdg.de

\section{Prof. Dr. Michael Meinecke}

Institute of Cellular Biochemistry

University Medical Centre, Georg-August University Göttingen

Humboldtallee 23, 37073 Göttingen

甾+49 (0)551398189 $₫$ michael.meinecke@med.uni-goettingen.de

Date of Disputation: 


\section{Affidavit}

I hereby declare that my doctoral thesis entitled

"Myofibroblast differentiation in hypoxia: a novel role for ArhGAP29"

has been written independently with no other sources and aids than quoted.

Göttingen, February 2019

Lisa Leinhos 


\section{Published data}

The presented data in this doctoral thesis were published as an original research article before the submission date.

"Hypoxia suppresses myofibroblast differentiation by changing RhoA activity"

Leinhos, Lisa; Peters, Johannes; Krull, Sabine; Helbig, Lena; Vogler, Melanie; Levay, Magdolna; van Belle Gijsbert J.; Ridley, Anne J.; Lutz, Susanne; Katschinski, Dörthe M.; Zieseniss, Anke (2019): Hypoxia suppresses myofibroblast differentiation by changing RhoA activity. Journal of Cell Science, 132: jcs223230 DOI: 10.1242/jcs.223230. 


\section{List of content}

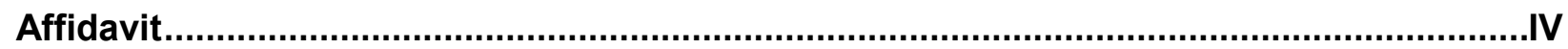

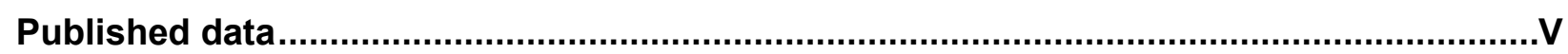

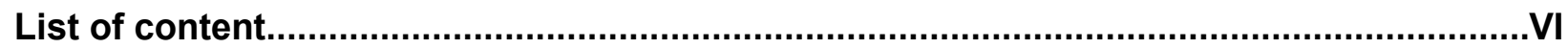

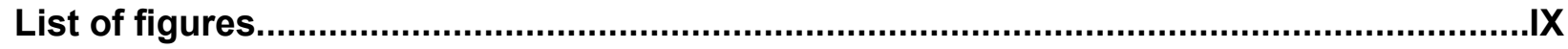

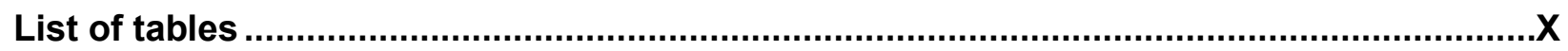

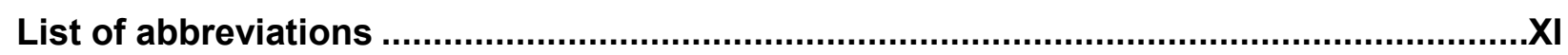

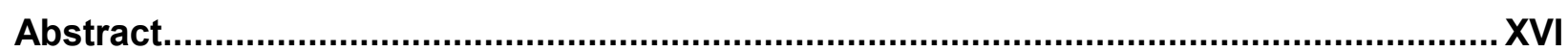

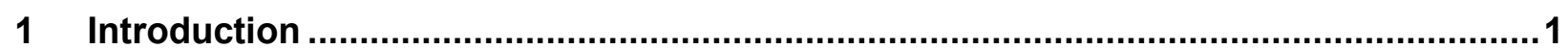

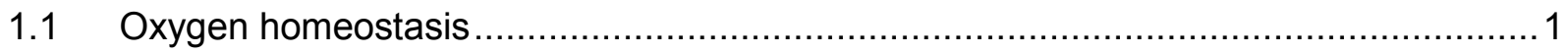

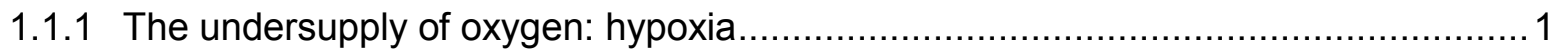

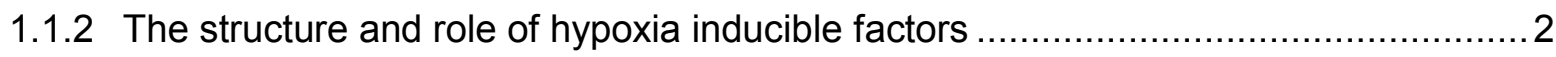

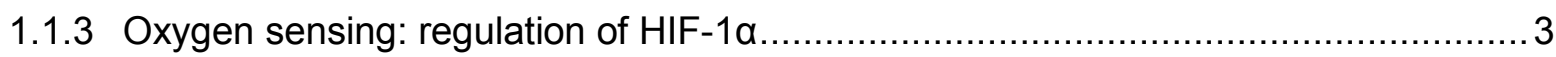

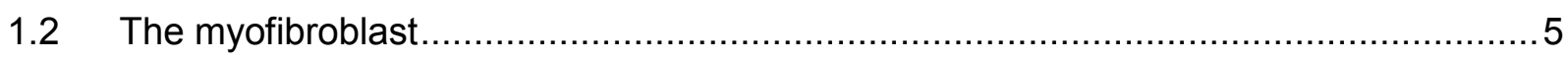

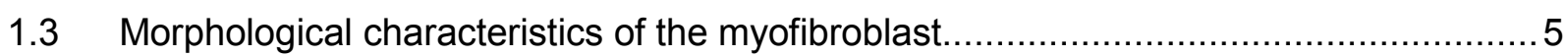

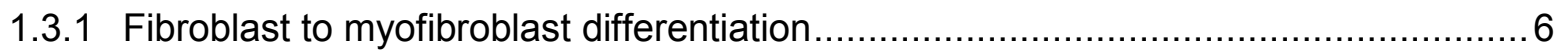

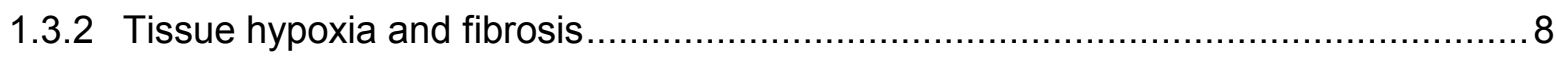

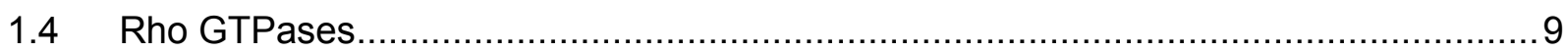

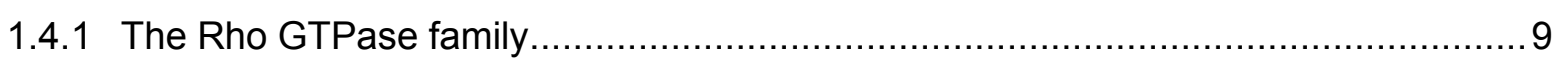

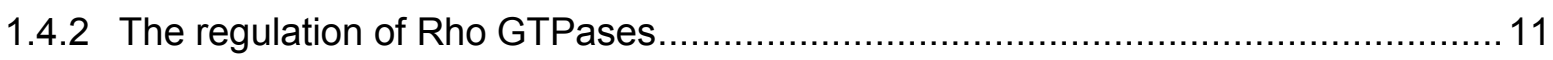

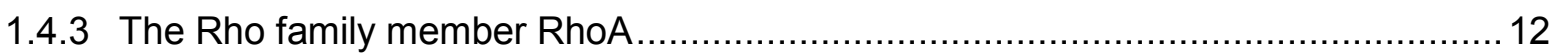

1.4.4 The Rho GTPase activating protein ArhGAP29 ….............................................. 14

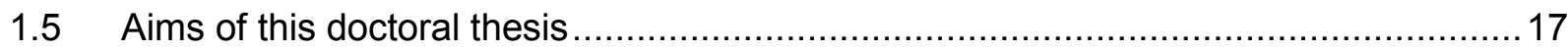

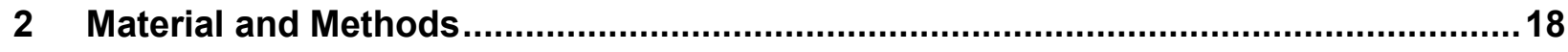

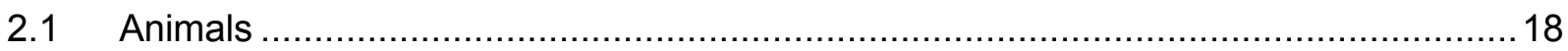

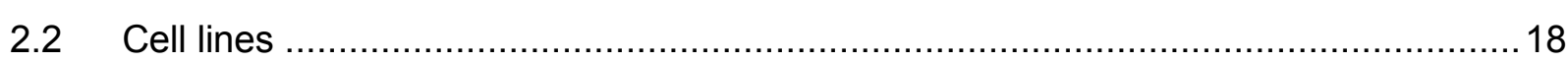

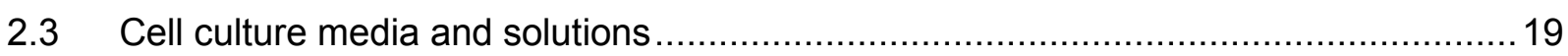

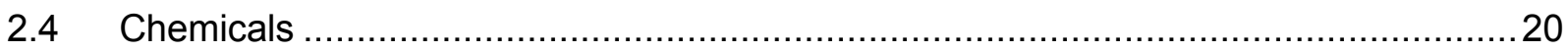

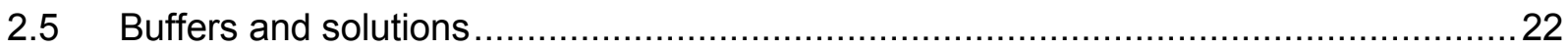

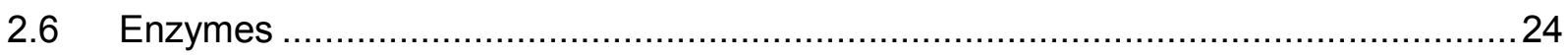

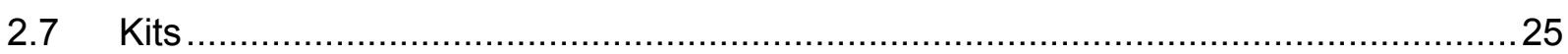

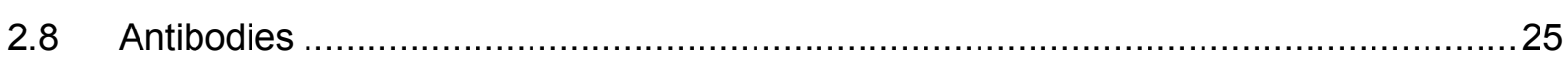

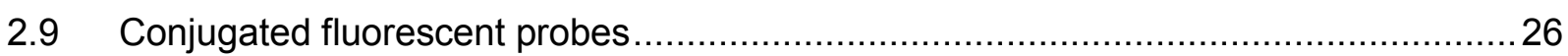

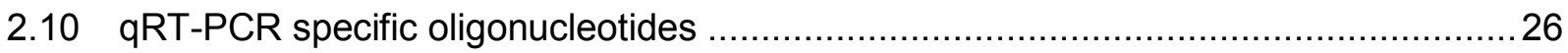

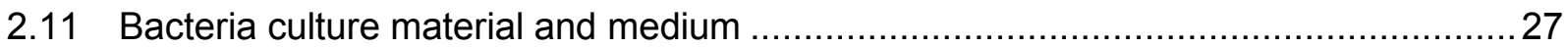

2.12 Bacterial strains

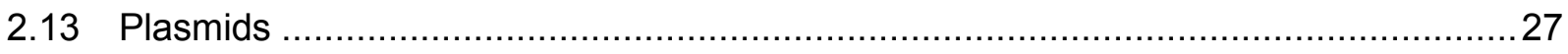

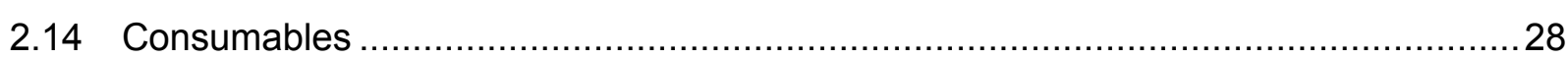




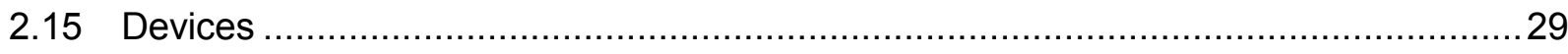

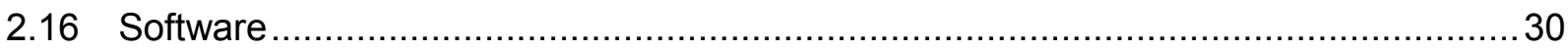

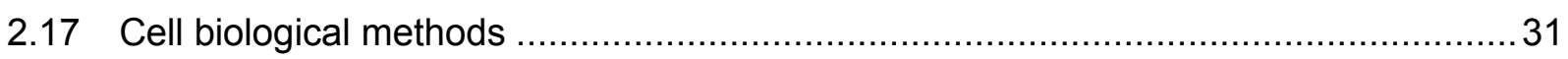

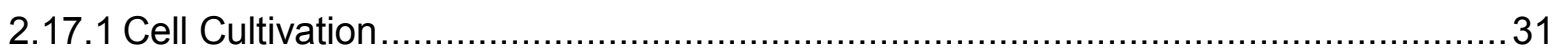

2.17.2 Isolation and cultivation of murine primary skin fibroblasts ................................... 31

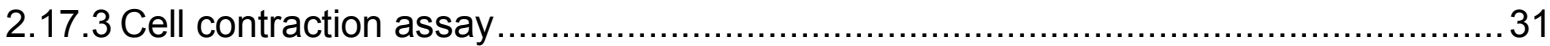

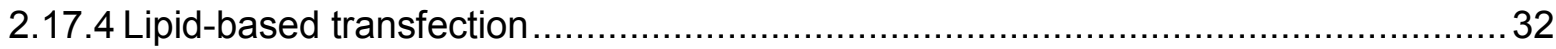

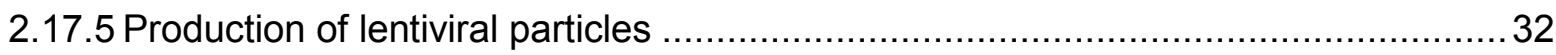

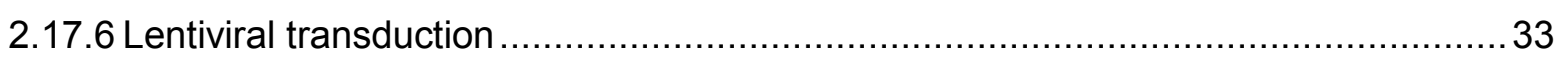

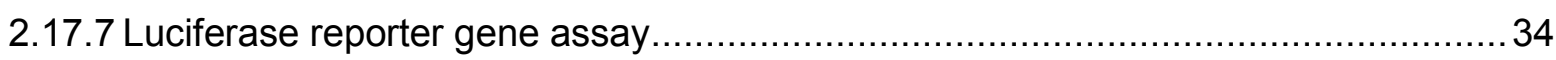

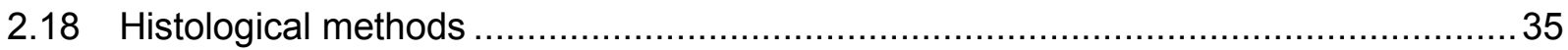

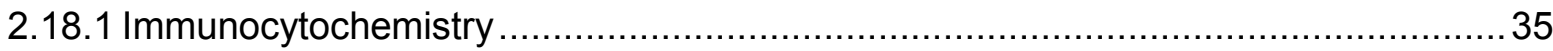

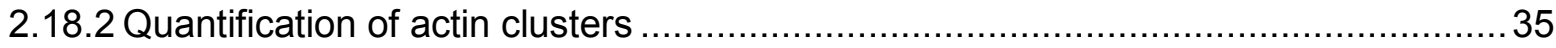

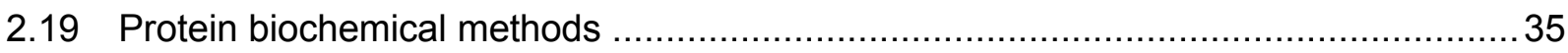

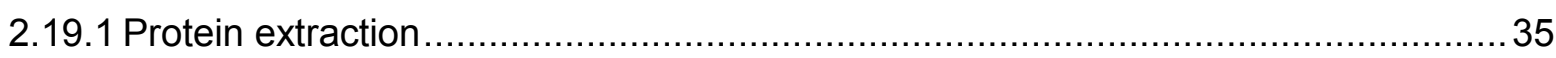

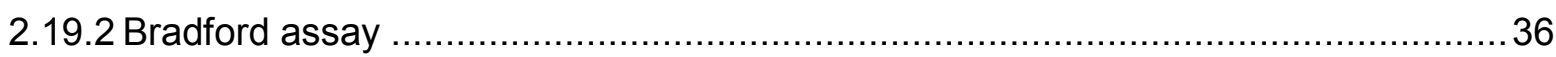

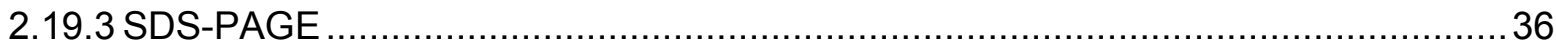

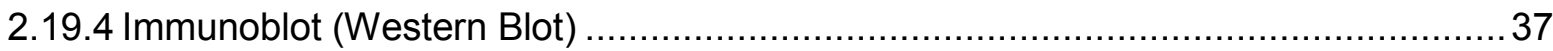

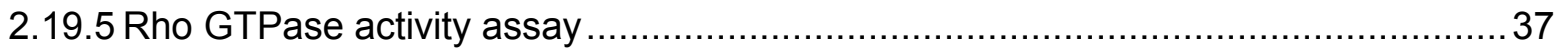

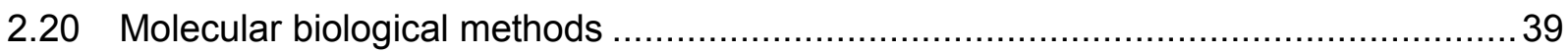

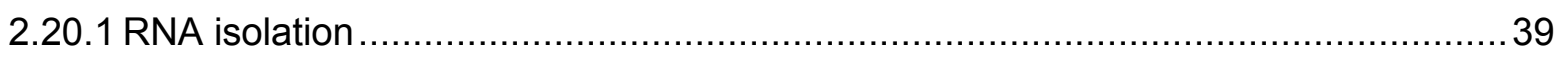

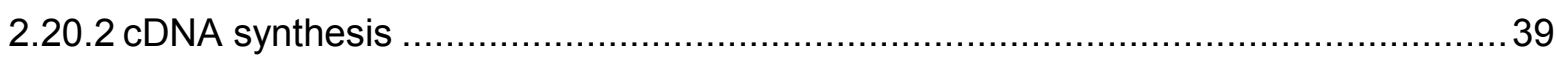

2.20.3 Quantitative real-time PCR (qRT-PCR) ......................................................... 40

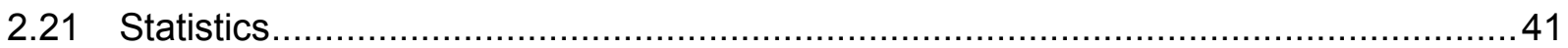

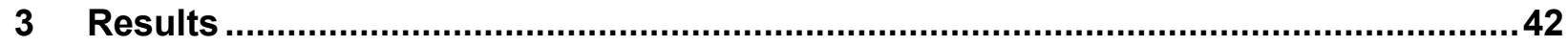

3.1 Hypoxia impairs myofibroblast differentiation and contractile function ..................... 42

3.1.1 The myofibroblast markers $\alpha$ smooth muscle actin and transgelin are decreased in hypoxia.....

3.1.2 The stimulating effect of transforming growth factor- $\beta$ on the myofibroblast differentiation is blunted in hypoxia

3.1.3 The ability of primary fibroblasts to develop contractile forces is diminished in hypoxia.

3.2 The hypoxia-mediated repression of myofibroblast differentiation is accompanied by

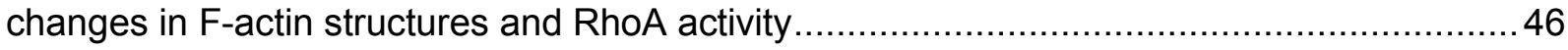

3.2.1 F-actin assembly is distinctive in normoxia and hypoxia ................................46

3.2.2 Hypoxia induces dynamic changes of RhoA activity .................................... 47

3.3 The Rho GTPase Activating Protein ArhGAP29 expression is induced in hypoxia ..... 49

3.3.1 ArhGAP29 dynamics are transiently induced in hypoxia ....................................50

3.4 The hypoxic induction of ArhGAP29 is HIF-1 $1 \alpha$ dependent ........................................50 
3.5 Knockdown of ArhGAP29 impacts RhoA activity ............................................... 51

3.5.1 F-actin formation is changed by knockdown of ArhGAP29 .................................53

3.5.2 MRTF-A localisation is altered in ArhGAP29 knockdown fibroblasts .......................54

3.5.3 ArhGAP29 knockdown results in altered SRE-dependent promoter activity and

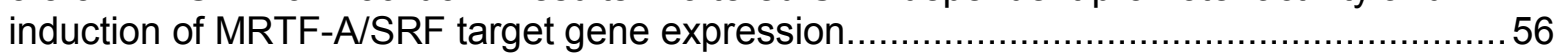

3.6 The knockdown of ArhGAP29 in primary fibroblasts prevents the impairment of

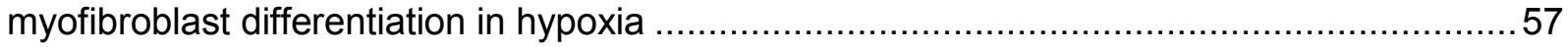

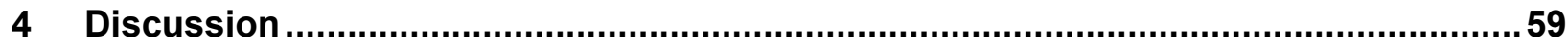

4.1 Hypoxia is a negative modulator of myofibroblast differentiation and function ...........60

4.2 ArhGAP29 is a regulator of RhoA activity in hypoxia ......................................... 61

4.3 RhoA activity and MRTF-A signalling are modulated by ArhGAP29 expression in

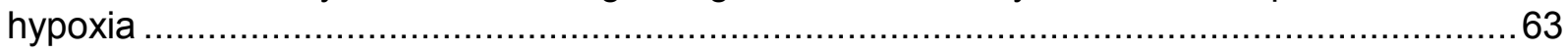

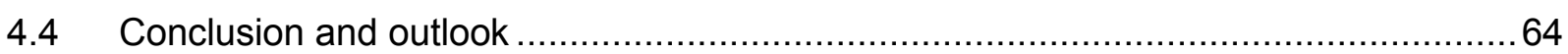

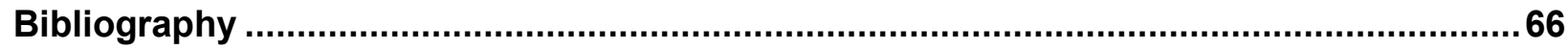

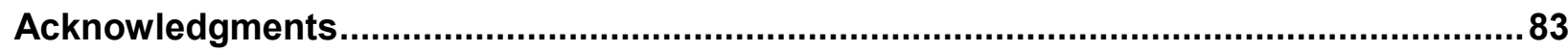




\section{List of figures}

Figure 1: Schematic representation of the HIF-1 $\alpha$ and HIF- $\beta$ domain structure. 3

Figure 2: Illustration of HIF regulation in normoxia and hypoxia. 4

Figure 3: Illustration of the myofibroblast differentiation principle. 7

Figure 4: The Rho GTPase family 10

Figure 5: Schematic of the Rho GTPase regulation.... 11

Figure 6: Schematic overview of the ArhGAP29 regulatory pathway. 14

Figure 7: Hypoxia impairs fibroblast to myofibroblast differentiation.

Figure 8: Hypoxia diminishes the stimulating effect of TGF- $\beta$ on the myofibroblast differentiation 44

Figure 9: Hypoxia affects the contraction ability of myofibroblasts 45

Figure 10: The hypoxia-mediated impairment of myofibroblast differentiation is paralleled by changes of F-actin structures 46

Figure 11: The hypoxia-mediated impairment of myofibroblast differentiation is paralleled by altered activity of RhoA

Figure 12: Dynamic changes of RhoA activity in hypoxia in L929 fibroblasts and mouse embryonic fibroblasts (MEF)

Figure 13: Hypoxic induction of ArhGAP29 is linked to the HIF pathway

Figure 14: Knockdown of ArhGAP29 in L929 fibroblasts results in increased RhoA activity. ....5 52

Figure 15: ArhGAP29 knockdown results in the remodelling of the actin cytoskeleton. 53

Figure 16: ArhGAP29 knockdown results in enhanced nuclear localisation of MRTF-A. 55

Figure 17: SRE-dependent promoter activity and induction of MRTF-A/SRF target gene expression are altered upon knockdown of ArhGAP29.

Figure 18: Knockdown of ArhGAP29 prevents the hypoxia-mediated myofibroblast dedifferentiation of primary fibroblasts

Figure 19: Illustrated summary of the role of ArhGAP29 in myofibroblast differentiation under hypoxic conditions 


\section{List of tables}

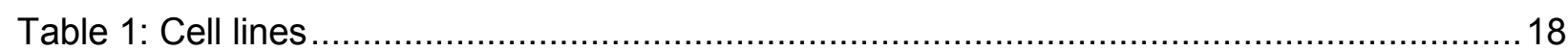

Table 2: Cell culture medium, supplements and supplies ................................................. 19

Table 3: Cell culture medium components and solutions .................................................... 19

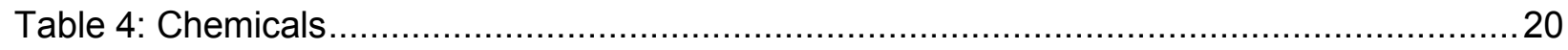

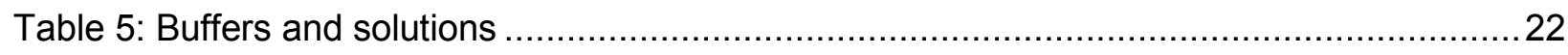

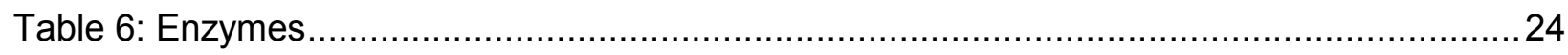

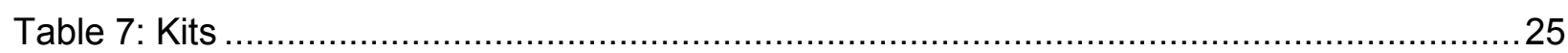

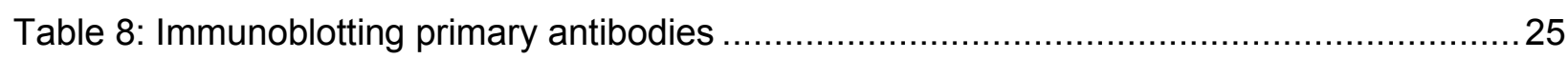

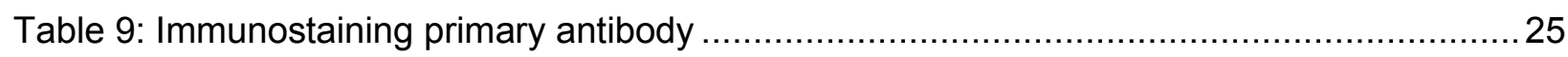

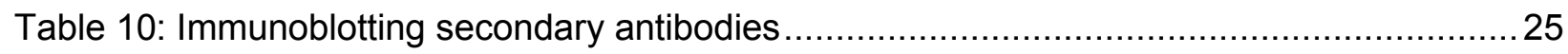

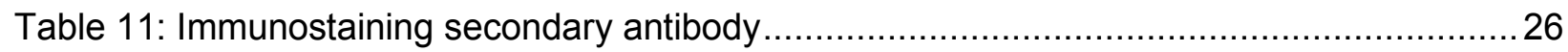

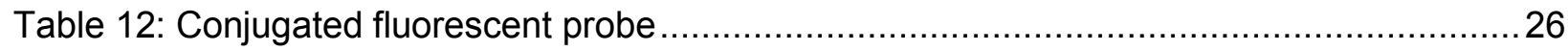

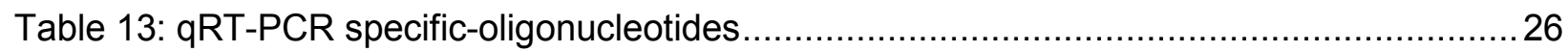

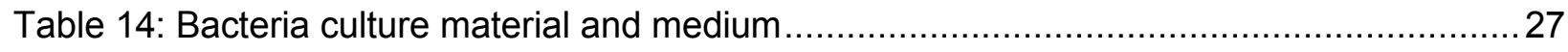

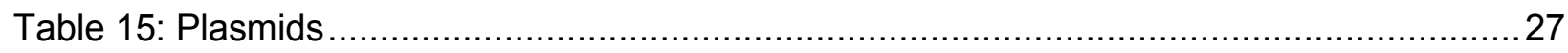

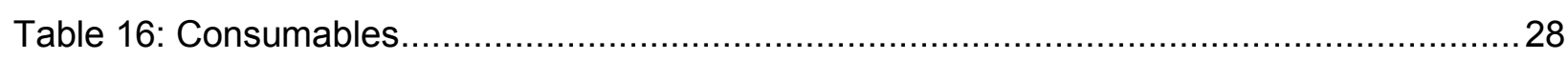

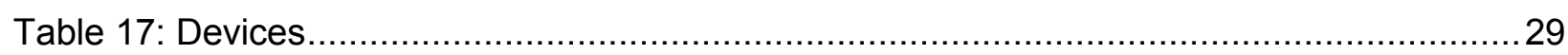

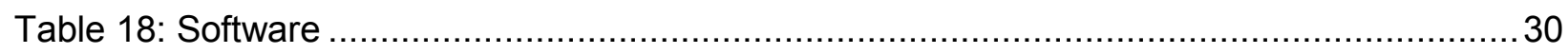

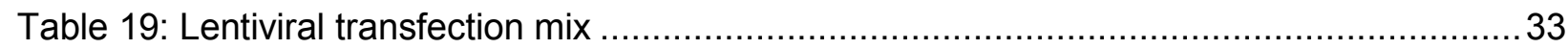

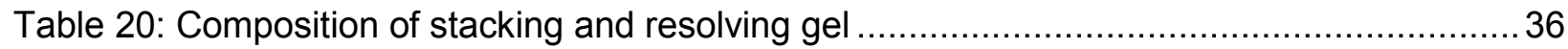

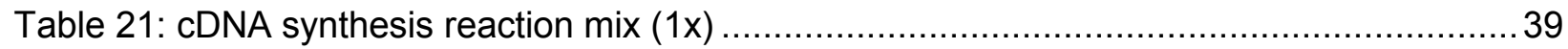

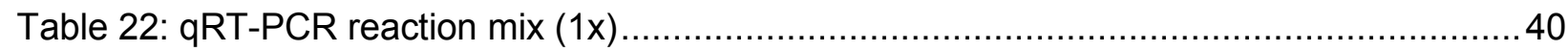

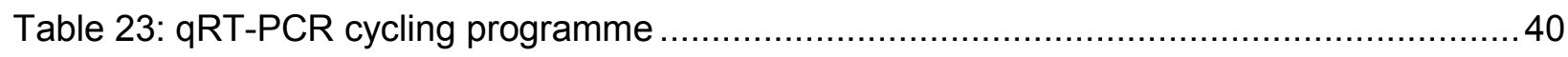




\section{List of abbreviations}

A

$\begin{array}{ll}\text { ADP } & \text { Adenosine diphosphate } \\ \text { APS } & \text { Ammonium persulfate } \\ \text { ARNT } & \text { Aryl hydrocarbon receptor nuclear translocator } \\ \text { ATP } & \text { Adenosine triphosphate } \\ \text { B } & \\ \text { bHLH-PAS } & \text { Basic helix-loop-helix PER-ARNT-SIM (domain) } \\ \text { BSA } & \text { Bovine serum albumin } \\ \text { C } & \\ \text { CBP } & \text { CREB-binding protein } \\ \text { Cdc42 } & \text { Cell division control protein 42 homolog } \\ \text { cDNA } & \text { Complementary DNA } \\ \text { CO } 2 & \text { Carbon dioxide } \\ \text { C-TAD } & \text { C-terminal transactivation domain } \\ \text { CTGF } & \text { Connective tissue growth factor } \\ \text { D } & \end{array}$

DAPI 4',6-Diamidin-2-phenylindol

DMEM Dulbecco's modified Eagle's medium

DMOG Dimethyloxaloylglycine

DNA Deoxyribonucleic acid

dNTP Desoxyribonukleotidtriphosphat

E

ECL Enhanced chemiluminescence

ECM Extracellular matrix

ED-A Extra Domain-A (fibronectin)

EDTA Ethylenediaminetetraacetic acid

EPO Erythropoietin

et al. Latin: et alii / et aliae, and others

$\mathbf{F}$

F-actin Filamentous actin

FAM 6-Carboxyfluorescein

FCS Fetal calf serum

FIH Factor inhibiting HIF 


\begin{tabular}{|c|c|}
\hline fwd. & Forward (primer) \\
\hline \multicolumn{2}{|l|}{ G } \\
\hline G-actin & Globular actin \\
\hline GAP & Rho GTPase-activating protein \\
\hline GDI & Guanine nucleotide dissociation inhibitor \\
\hline GDP & Guanosine diphosphate \\
\hline GEF & Rho guanine nucleotide-exchange factor \\
\hline GFP & Green fluorescent protein \\
\hline GST & Glutathione-S-transferase \\
\hline GTP & Guanosine triphosphate \\
\hline \multicolumn{2}{|l|}{$\mathbf{H}$} \\
\hline $\mathrm{H}_{2} \mathrm{O}$ & Water \\
\hline $\mathrm{H}_{2} \mathrm{O}_{2}$ & Hydrogen peroxide \\
\hline HEPES & 4-(2-hydroxyethyl)-1-piperazineethanesulfonic acid \\
\hline HIF & Hypoxia-inducible factor \\
\hline HRE & Hypoxia-responsive element \\
\hline HRP & Horseradish peroxidase \\
\hline \multicolumn{2}{|l|}{$\mathbf{I}$} \\
\hline i.e. & Latin: id est, that is to say \\
\hline \multicolumn{2}{|l|}{$\mathbf{K}$} \\
\hline kB & Kilo base pairs \\
\hline $\mathrm{kd}$ & Knockdown \\
\hline $\mathrm{kDa}$ & Kilodalton \\
\hline ko & Knockout \\
\hline \multicolumn{2}{|l|}{$\mathbf{M}$} \\
\hline M & Molar \\
\hline MAP & Mitogen-activated protein \\
\hline MBS & Myosin-binding subunit \\
\hline mDia & Mammalian diaphanous-related formin \\
\hline MEF & Mouse embryonal fibroblasts \\
\hline MI & Myocardial infarction \\
\hline MLC & Myosin light chain \\
\hline MP & Megapixel \\
\hline $\mathrm{miR}$ & MicroRNA \\
\hline
\end{tabular}




\begin{tabular}{|c|c|}
\hline mRNA & Messenger RNA \\
\hline ms12 & Murine ribosomal protein $\mathrm{S} 12$ \\
\hline \multicolumn{2}{|l|}{$\mathbf{N}$} \\
\hline n.a. & Not available \\
\hline $\mathrm{NaCl}$ & Sodium chloride \\
\hline NEAA & Non-Essential Amino Acids \\
\hline N-TAD & $\mathrm{N}$-terminal transactivation domain \\
\hline NSCL/P & Nonsyndromic cleft lip and/or palate \\
\hline \multicolumn{2}{|l|}{$\mathbf{0}$} \\
\hline $\mathrm{O}_{2}$ & Oxygen \\
\hline ODDD & Oxygen-dependent degradation domain \\
\hline \multicolumn{2}{|l|}{$\mathbf{P}$} \\
\hline $\mathrm{p}$ & P-value \\
\hline PCF & Primary cardiac fibroblasts \\
\hline PCR & Polymerase Chain Reaction \\
\hline PBS & Phosphate-buffered saline \\
\hline PFA & Paraformaldehyde \\
\hline PHD & Prolyl-4-hydroxylase domain enzyme \\
\hline $\mathrm{PI}-3$ & Phosphatidylinositol 3 \\
\hline PMSF & Phenylmethane sulfonyl fluoride \\
\hline $\mathrm{pO}_{2}$ & Partial oxygen pressure \\
\hline $\mathrm{P} / \mathrm{S}$ & Penicillin/streptomycin \\
\hline PSF & Primary skin fibroblasts \\
\hline PTP & protein-tyrosine phosphatase \\
\hline $\mathrm{pVHL}$ & Von-Hippel Lindau tumor suppressor protein \\
\hline \multicolumn{2}{|l|}{$\mathbf{Q}$} \\
\hline qRT-PCR & Quantitative real-time PCR \\
\hline \multicolumn{2}{|l|}{$\mathbf{R}$} \\
\hline Rac1 & Ras-related C3 botulinum toxin substrate 1 \\
\hline Radil & Ras-association and dilute domain-containing protein \\
\hline Rap & Ras-related GTPase/protein \\
\hline Rasip1 & Ras-interacting protein 1 \\
\hline RBD & Rho binding domain \\
\hline rev. & Reverse (primer) \\
\hline
\end{tabular}




$\begin{array}{ll}\text { RhoA } & \text { Ras homolog gene family member A } \\ \text { RT } & \text { Room temperature } \\ \text { RNA } & \text { Ribonucleic acid } \\ \text { ROCK } & \text { Rho- associated coiled coil containing protein kinase } \\ \text { ROX } & \text { 5-carboxy-X-rhodamine } \\ \text { S } & \\ \text { SDS } & \text { Sodium dodecyl sulfate } \\ \text { SEM } & \text { Standard error of the mean } \\ \text { SM } & \text { Smooth muscle actin } \\ \text { SRE } & \text { Serum response element } \\ \text { SRF } & \text { Serum response factor } \\ \text { T } & \\ \text { Tab. } & \text { Table } \\ \text { Tagln } & \text { Transgelin } \\ \text { TBS-T } & \text { TRIS-buffered saline with Tween20 } \\ \text { TEMED } & \text { Tetramethylethylenediamine } \\ \text { TGFR } & \text { TGF- } \beta \text { receptor } \\ \text { TGF- } \beta & \text { Transforming growth factor- } \beta \\ \text { TRIS } & \text { Tris(hydroxymethyl)-aminomethane } \\ \text { V } & \\ \text { VEGF } & \text { Vascular endothelial growth factor } \\ \text { W } & \\ \text { wt } & \text { Wildtype } \\ \text { Y } & \\ \text { YAP } & \end{array}$




\section{Units}

$\begin{array}{ll}{ }^{\circ} \mathrm{C} & \text { centigrade } \\ \mathrm{xg} & \text { gravitational force } \\ \mathrm{g} & \text { gram } \\ \mathrm{h} & \text { hour } \\ \mathrm{I} & \text { litre } \\ \mathrm{m} & \text { meter } \\ \mathrm{mg} & \text { milligram } \\ \mathrm{min} & \text { minute } \\ \mathrm{U} & \text { units } \\ \mathrm{V} & \text { volt }\end{array}$

\section{Prefix}

C centi $\left(10^{-2}\right)$

k

kilo $\left(10^{3}\right)$

$\mu$

micro $\left(10^{-6}\right)$

$\mathrm{m}$

milli $\left(10^{-3}\right)$ 


\section{Abstract}

Myofibroblasts are crucial for normal wound healing and tissue remodelling and play an essential role in the pathogenesis of ischemic tissue fibrosis. Due to their contractile features, myofibroblasts support wound closure; however, overactive myofibroblasts will cause severe scarring that can lead to organ dysfunction. The transition of fibroblasts to myofibroblasts is initiated by a wide range of microenvironmental stimuli, such as mechanical stress, cytokine signalling or alteration of oxygen supply. However, the oxygen-dependent molecular regulatory mechanisms underlying the myofibroblast programme remain unclear.

In this doctoral thesis, the effect of reduced oxygen availability (hypoxia) on the myofibroblast differentiation process was investigated in vitro. Under hypoxic conditions, decreased expression of aSMA, the signature protein of myofibroblast differentiation, and actin filament remodelling were paralleled by reduced cell contractility. This led to the conclusion that hypoxia reverts myofibroblast differentiation. Dedifferentiation of myofibroblasts was also observed when RhoA activity was inhibited in normoxia. In this study, reduced RhoA activity was observed in hypoxia, indicating that oxygen availability influences RhoA activity and myofibroblast differentiation. The Rho GTPase activating protein ArhGAP29 was identified to be involved in fine-tuning the RhoA response in hypoxia as its expression is induced in hypoxia in a HIF-1 $\alpha$-dependent manner.

By regulating RhoA activity, ArhGAP29 plays an important role in the MRTF/SRF signalling pathway and thus has a critical impact on the myofibroblast differentiation programme in hypoxia. The oxygenation state of tissue is of importance in the wound healing process, hence the presented new link between hypoxia and the regulation of the RhoA-MRTF/SRF signalling axis provides both new insights into the molecular mechanisms underlying the myofibroblast differentiation and promising therapeutic targets for tissue remodelling and fibrosis in an ischemic context. 


\section{Introduction}

\subsection{Oxygen homeostasis}

\subsubsection{The undersupply of oxygen: hypoxia}

With rising oxygen levels on earth a billion years ago, the development of effective strategies to use oxygen for the metabolism preserved the survival of evolving aerobic organisms (Dunwoodie, 2009). Therefore, it is not surprising that the undersupply of oxygen is challenging and even life-threatening for aerobes. When the cellular oxygen demand exceeds the level of oxygen supply, a condition termed hypoxia occurs. Hypoxia is further defined by a reduced partial pressure of oxygen $\left(\mathrm{pO}_{2}\right)$ compared to the physiological $\mathrm{pO}_{2}$ in the respective tissue (Sen, 2009). Hence, every organ and tissue has an individual physiological normoxic state.

Hypoxia can arise from physiological and pathological circumstances. In a physiological context, the development of mammalian embryos takes place in a hypoxic environment, for example ensuring normal heart and placenta formation (Dunwoodie, 2009). Enhanced physical activity can also result in hypoxia if the cardiovascular system cannot cope with the increased oxygen demand of exercising muscles. This is often accompanied by the switch to anaerobic metabolism (Garvey et al., 2012). Exposure to high altitudes and consequently the reduction of $\mathrm{pO}_{2}$ generally leads to physiologically induced hypoxia and further to pathophysiological consequences such as high-altitude illness (Hackett and Roach, 2001). The pathological responses that hypoxia is involved in include: inflammation, wound healing, cancer signalling and ischemia. Disrupted blood flow, often following myocardial infarction (MI), results in ischemic tissue, including hypoxia.

The maintenance of oxygen homeostasis by responding and adapting to reduced oxygen levels is important to prevent cell dysfunction and in more extreme circumstances cell death. These responses range from acute responses, such as enhanced ventilation and the metabolic switch to anaerobic glycolysis to chronical adaption through the activation of gene transcription (Michiels, 2004). This can result in the stimulation of angiogenesis and erythropoiesis (Michiels, 2004). There are several oxygen-sensing pathways involved in regulating the hypoxic response, including the hypoxia inducible factors (HIFs), the key inducers of the hypoxic transcriptional response (Michiels, 2004; Dunwoodie, 2009). 


\subsubsection{The structure and role of hypoxia inducible factors}

HIFs form a unique family of proteins that are essential for the transcriptional cellular response and adaption to hypoxia. The heterodimeric DNA-binding complex HIF consists of an unstable $\alpha$ - and a stable $\beta$-subunit, also known as the aryl hydrocarbon receptor nuclear translocator (ARNT) (Wang et al., 1995). Three different isoforms of the oxygen-sensitive HIF- $\alpha$ subunits are known: HIF1- $\alpha$, HIF-2 $\alpha$ and HIF-3 $\alpha$. HIF-1 $\alpha$ was the first described isoform. Semenza and colleagues discovered it while they were studying the hypoxic induction of erythropoietin (EPO), a hormone crucial for erythrocyte production (Semenza and Wang, 1992; Wang and Semenza, 1995).

Both HIF-1 $\alpha$ and HIF-2 $\alpha$ are essential for normal embryogenesis. Genetic knockout of HIF$1 \alpha$ in mice results in impaired vascularisation, severe defects of the neural tube and heart, causing lethality early in gestation (Ryan et al., 1998; lyer et al., 1998). HIF-2a deficiency is also lethal as HIF-2 $\alpha$ knockout mouse embryos develop brachycardia and vascular defects (Tian et al., 1998; Peng et al., 2000). Compared to HIF-1 $\alpha$ and HIF-2 $\alpha$, the biological role of HIF-3a is yet to be elucidated. However, studies in mice report a role of HIF-3a in lung development, as the lack of HIF-3a results in branching defects and fewer alveoli (Huang et al., 2013).

There are two paralogs of the HIF- $\beta$ subunit described: ARNT and ARNT2 (Graham and Presnell, 2017). Unlike the highly oxygen-dependent HIF- $\alpha$ subunits, the HIF- $\beta$ subunits are not responsive to oxygen (Weidemann and Johnson, 2008). HIF-1 $\alpha$ and ARNT are ubiquitously expressed, whereas HIF-2 $\alpha$, HIF-3 $\alpha$, and ARNT2 are expressed in a cell restricted manner (Rankin and Giaccia, 2008).

The $\alpha$ and $\beta$ subunits of the HIF-heterodimer consist of the basic helix-loop-helix PER-ARNTSIM (bHLH-PAS) domains for the interaction of the subunits and DNA binding (Fig. 1), thus allowing them to bind hypoxia-responsive elements (HREs, core sequence G/ACGTG) in or outside promotor regions of its target genes (Schofield and Ratcliffe, 2005). The HIF- $\alpha$ domain structure includes two transactivation domains (C-TAD and N-TAD) and an oxygendependent degradation domain (ODDD), essential for transcriptional activity (Pugh et al., 1997; Huang et al., 1998). The ODDD of HIF-1 $\alpha$ and HIF-2 $\alpha$ possesses conserved proline residues (Pro402/Pro564 for HIF-1 $\alpha$ and Pro405/Pro531 for HIF-2 $\alpha$ ), which enables the HIF$\alpha$ domain to interact with the von Hippel-Lindau tumour suppressor protein ( $p V H L$ ) via transprolyl-4-hydroxylation (Schofield and Ratcliffe, 2005; Haase, 2012). Furthermore, both HIF$1 \alpha$ and HIF-2 $\alpha$ have a highly conserved asparagine (Asn803 for HIF-1 $\alpha$, Asn847 for HIF-2 $\alpha$ ) within the C-TAD (Dengler et al., 2014). 


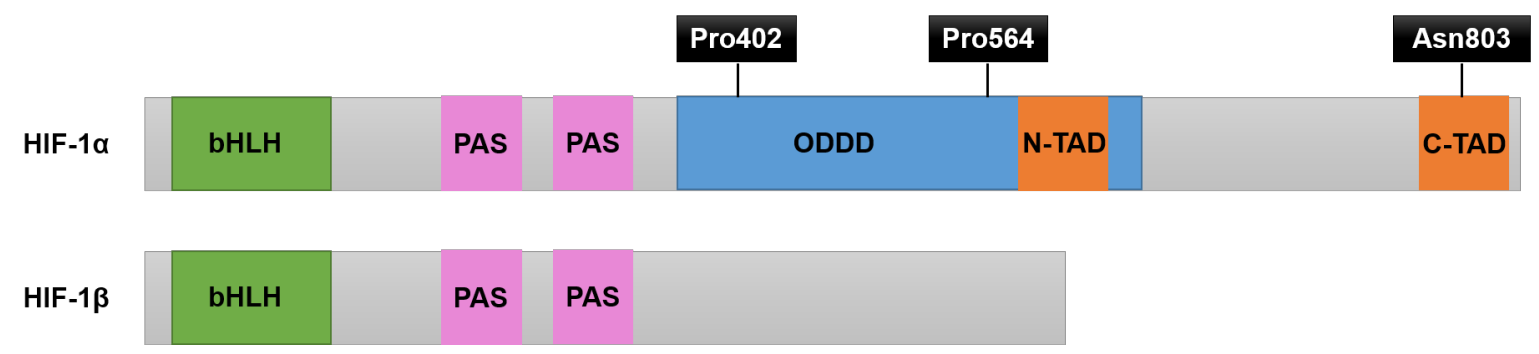

Figure 1: Schematic representation of the HIF-1 $\alpha$ and HIF- $\beta$ domain structure. The hypoxia inducible factor (HIF)-1 $\alpha$ and HIF-1 $\beta$ subunits have structural similarities as they both consist of the basic helix-loop-helix PER-ARNT-SIM (bHLH-PAS) domains, which are important for DNA binding and interaction. HIF-1 $\alpha$ is hydroxylated at the proline residues Pro402 and Pro564 that are located in the oxygen-dependent degradation domain (ODDD), and at an asparagine (Asn803) within the C-terminal transactivation domain (C- TAD).

\subsubsection{Oxygen sensing: regulation of HIF-1a}

The regulation of HIF-1a relies on an oxygen-dependent mechanism. Under normoxic conditions, the HIF-1 $\alpha$ subunit is hydroxylated by PHDs, resulting in ubiquitination and proteasomal degradation.

PHDs are $\mathrm{Fe}(\mathrm{II})$ and 2-oxoglutarate (2-OG)-dependent dioxygenases, that require ascorbate and molecular oxygen for catalytic activity (Myllyharju and Kivirikko, 1997). The oxygen atoms are utilised for oxidative decarboxylation of 2-OG, resulting in $\mathrm{CO}_{2}$ and succinate and for the integration into a peptidyl proline of HIF-1a, forming a hydroxyproline (McNeill et al., 2002; Hewitson et al., 2002; Berra et al., 2006; Kaelin and Ratcliffe, 2008). The prolyl hydroxylase domain (PHD) enzymes PHD1, PHD2 and PHD3 hydroxylate the HIF-1a proline residues Pro402 and Pro564 if oxygen and the cofactors are available (Semenza, 2009). The hydroxylation of the proline residues allows the pVHL ubiquitin-protein E3 ligase complex to bind resulting in ubiquitination and proteasomal degradation of HIF-1a (Fig. 2) (Semenza, 2009). The constant degradation of the HIF-1 $\alpha$ after translation leads to a short half-life and thus to low basal levels of HIF-1a protein in normoxia (Berra et al., 2001). Furthermore, the C-TAD of HIF-1 $\alpha$ contains an asparagine residue (Asn803). In normoxic conditions, Asn803 is hydroxylated by factor inhibiting HIF $(F I H)$ hindering the co-activator p300 to bind and to initiate transcriptional activity (Schofield and Ratcliffe, 2005; Kaelin and Ratcliffe, 2008).

Hypoxia inhibits the oxygen-dependent PHD-mediated hydroxylation (Semenza, 2009). The effect of hypoxia on PHDs can also be generated artificially, for example with the 2oxoglutarate analog dimethyloxalylglycine (DMOG), which is a competitive inhibitor for the PHDs (Jaakkola et al., 2001; Weidemann and Johnson, 2008). If not degraded, HIF-1a translocates into the nucleus and forms a stable complex with the HIF-1 $\beta$ subunit. The 
complex binds to the core sequence of the HREs, together with the transcriptional coactivators p300 and the CREB-binding protein (CBP), resulting in the transcription of HIF target genes (Schofield and Ratcliffe, 2005). Over 100 HIF target genes are known, many of them are involved in regulatory processes such as cell growth and survival, differentiation, proliferation, metabolism and angiogenesis (Weidemann and Johnson, 2008). HIF target genes include EPO, which stimulates erythropoiesis, the vascular endothelial growth factor (VEGF) to restore the oxygen and nutrition supply by vascularisation and the glucose transporter-1 (GLUT-1), upregulating the cellular glucose transport in hypoxia (Wang et al., 1995; Hayashi et al., 2004; Desmoulière et al., 2005; Hong et al., 2014; Darby and Hewitson, 2016).

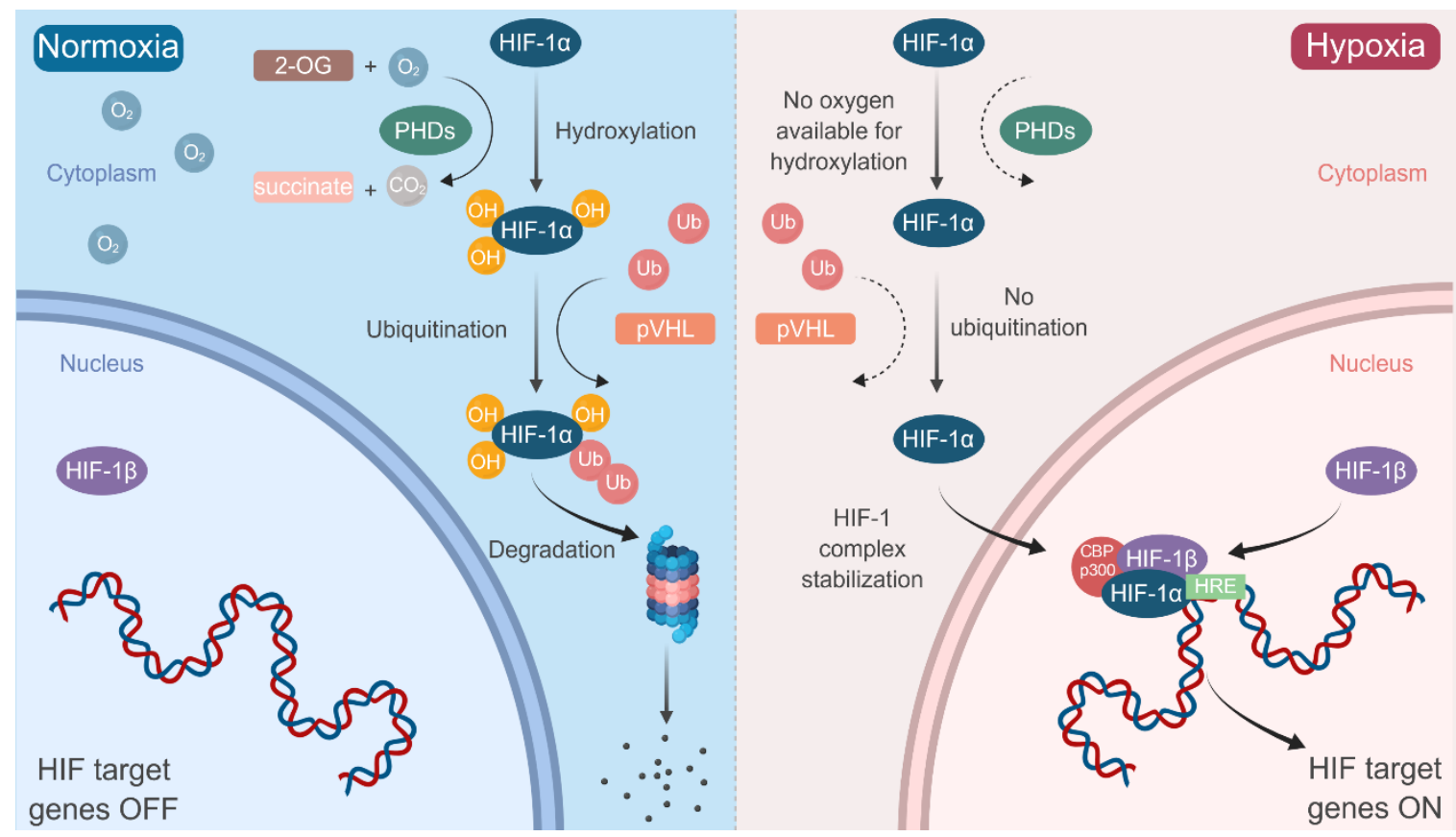

Figure 2: Illustration of HIF regulation in normoxia and hypoxia. In normoxia the hypoxia inducible factor (HIF)-1 $\alpha$ is hydroxylated by prolyl hydroxylase domain enzymes (PHDs) in a 2-oxoglutarate (2$\mathrm{OG}$ ) and oxygen-dependent manner, resulting in ubiquitination (Ub) by the von Hippel-Lindau tumour suppressor protein $\mathrm{E} 3$ ubiquitin ligase complex ( $\mathrm{pVHL}$ ) followed by proteasomal degradation. Under hypoxic conditions, the PHD-mediated hydroxylation is inhibited. HIF-1 $\alpha$ translocates into the nucleus and forms a stable complex with the HIF-1 $\beta$ subunit. Together with the transcriptional coactivators p300 and the CREB-binding protein (CBP), the HIF-1 complex binds to the core sequence of the hypoxia responsive element (HRE) which activates the transcription of HIF target genes. 


\subsection{The myofibroblast}

\subsection{Morphological characteristics of the myofibroblast}

Myofibroblasts display a unique specialised cell type, crucial for wound repair and tissue remodelling, but also involved in pathological conditions like fibrosis. In the early 1970s, Gabbiani and colleagues first described the myofibroblast phenotype as an activated fibroblast in granulation tissue of dermal wounds (Gabbiani et al. 1971). Early research defined myofibroblasts by their ultrastructural morphology as an intermediate phenotype between common fibroblasts and smooth muscle (SM) cells (Majno et al., 1971; Gabbiani et al., 1971). Indeed, the ultrastructural characteristics, such as dense microfilament bundles are quite similar to SM cells, whilst also showing fibroblast features, such as a prominent rough endoplasmic reticulum (Gabbiani et al., 1971). The most striking feature that separated myofibroblasts from fibroblasts was the ability to contract tissue (Gabbiani et al., 1971). The microfilament bundles of the myofibroblast end in the fibronexus, that are also indicated as focal adhesions (Dugina et al., 2001; Gabbiani, 2003). Focal adhesions form a mechanotransduction complex, allowing the myofibroblast to transfer the generated contractile force to the extracellular matrix (ECM) by connecting intracellular actin and extracellular fibronectin domains via transmembrane integrins (Gabbiani, 2003). This feature allows the myofibroblast to contract the surrounding ECM, promoting tissue remodelling and scar formation.

Furthermore, it has been reported that myofibroblasts, similar to SM cells, are connected via functional gap junctions (Gabbiani et al., 1978; Spanakis et al., 1998; Tomasek et al., 2002). With the development of advanced techniques, myofibroblast specific immunohistochemical markers were established. The most commonly used marker to distinguish myofibroblasts from fibroblasts is a smooth muscle actin (aSMA), which is expressed de novo by myofibroblasts and represents a typical actin isoform of vascular SM cells (Gabbiani, 2003; Hinz, 2007). Another myofibroblast marker is the contractility-promoting gene transgelin (Tagln or known as SM22a) (Scharenberg et al., 2014; Dolivo et al., 2017). Transgelin is an early SM differentiation marker, however, it is also likely to be present in fibroblasts, where it is regulated in a TGF- $\beta$-driven manner (Assinder et al., 2009). The actin-binding protein Tagln is involved in actin cytoskeleton remodelling, promoting cell motility and migration, as well as being involved in developmental processes such as the closure of the ventral body wall $(\mathrm{Yu}$ et al., 2008; Elsafadi et al., 2016; Aldeiri et al., 2017).

In addition, traditional SM cell markers, such as SM myosin heavy chain, smoothelin and hcaldesmon are used as negative labels of myofibroblasts (Darby et al., 2016). However, the distinction of myofibroblasts can be challenging, as some cells in vivo show typical characteristics of myofibroblasts but are negative for aSMA. These cells are called protomyofibroblasts 
and are predominantly present in specialised normal connective tissue (such as lung alveolar septa) or in early granulation tissue (open wounds); following activation, protomyofibroblasts become fully differentiated myofibroblasts (Tomasek et al., 2002).

\subsubsection{Fibroblast to myofibroblast differentiation}

The differentiation of a fibroblast to a myofibroblast is both a complex and an enigmatic process. The detailed molecular mechanisms underlying this differentiation process are not fully understood (Baum and Duffy 2011). The principal of myofibroblast differentiation relies on a defined pattern that is independent of their heterogeneous origin (Hinz et al. 2007). Although it is acknowledged that myofibroblasts predominantly originate from tissue-resident fibroblasts, other organ-specific progenitor cells have been reported (Hinz et al. 2007). For example, myofibroblasts found in the liver can differentiate from hepatic stellate cells (HSCs) and epithelial cells, whereas myofibroblasts in lung tissue derive from endothelial-tomesenchymal transition (Hinz et al. 2007). In general, fibroblasts respond to stress factors such as mechanical tension, cytokines and altered oxygenation with the initiation of the myofibroblast programme (Hinz 2007; Tomasek et al. 2002). Under healthy, physiological conditions, the main function of fibroblasts is the maintenance and synthesis of the ECM by integrating collagens, fibronectin and proteoglycans (McAnulty 2007; Nagalingam et al. 2018). The synthesised, cross-linked ECM also protects the fibroblasts from mechanical stress, except during ECM remodelling during tissue injury (Hinz et al. 2007; Tomasek et al. 2002).

Fibroblasts respond to mechanical changes of their microenvironment with the formation of stress fibers, resulting in a protomyofibroblast phenotype, an intermediate differentiation stage towards the mature myofibroblast (Fig. 3) (Tomasek et al. 2002). The protomyofibroblasts can further be stimulated to differentiate into myofibroblasts. Cell contact with rigid surfaces, like conventional plastic culture dishes, is also inducing a mechanical stress stimulus for fibroblasts. Thus, the protomyofibroblast represents a commonly observed phenotype of nearly all fibroblasts cultured on plastic surfaces and in the presence of foetal calf serum (Tomasek et al., 2002; Hinz, 2007). Protomyofibroblasts are able to exert low contractile forces, but they do not contain aSMA-positive stress fibers like the fully differentiated myofibroblast (Tomasek et al. 2002). The de novo expression of aSMA and its incorporation into actin stress fibers enhances the contractility and finally hallmarks the completion of myofibroblast differentiation (Fig. 3) (Hinz 2007). The contractile forces derive from actin-myosin interaction of the stress fibers (Parizi et al., 2000). The developed forces of the contracting myofibroblasts are transferred to the surrounding ECM via focal adhesions (Dugina et al., 2001; Gabbiani, 2003; Bochaton-Piallat et al., 2016). Focal adhesions are present in protomyofibroblasts and further develop to 'supermature' focal adhesions in myofibroblasts (Goffin 
et al. 2006; Yeung et al. 2005). These 'supermature' focal adhesions contribute to the cell contraction due to their strong ECM adhesion (Rønnov-Jessen and Petersen, 1996; Tomasek et al., 2002; Hinz and Gabbiani, 2003; Hinz et al., 2003; Goffin et al., 2006).

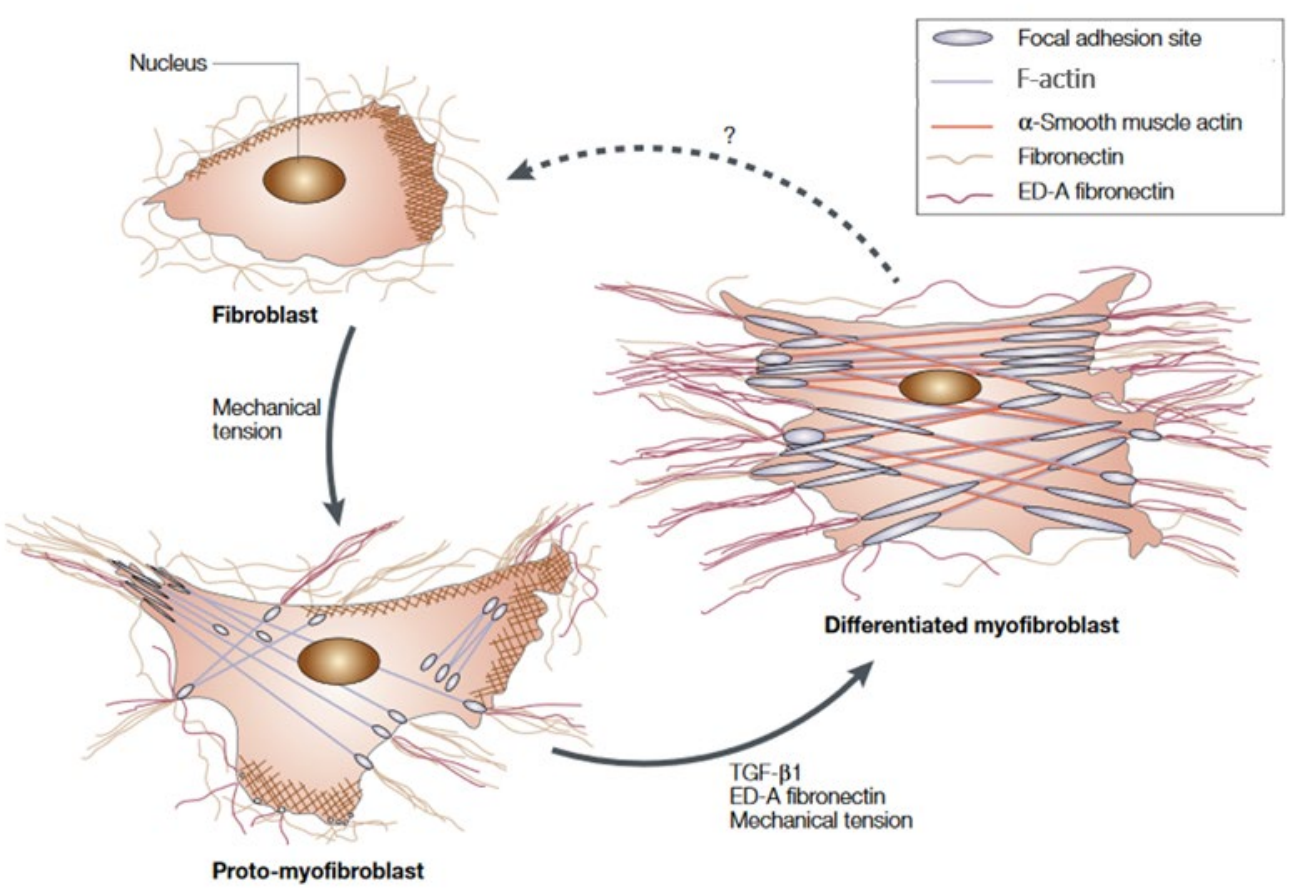

Figure 3: Illustration of the myofibroblast differentiation principle. Stress factors, such as mechanical tension lead to a fibroblast to protomyofibroblast differentiation. Protomyofibroblasts form stress fibers that terminate in the focal adhesion sites. Additional microenvironmental stimuli, such as transforming growth factor- $\beta$ (TGF- $\beta$ ), promote the myofibroblast differentiation. Myofibroblasts express $\alpha$ smooth muscle actin ( $\alpha$ SMA) de novo, which is incorporated into stress fibers terminating in large 'supermature' focal adhesions. Enhanced contractile forces are characteristic for the differentiated myofibroblasts. The myofibroblast contributed contractility and extracellular matrix components, i.e. splice variant extra domain-A (ED-A) fibronectin are essential for tissue remodelling. Dedifferentiation of the myofibroblast phentotype to fibroblasts (dashed arrow) is controversially discussed in the literature. Figure modified from Tomasek et al. (2002).

Mechanical stress alone is not enough to initiate myofibroblast differentiation. The presence of the cytokine transforming growth factor- $\beta 1$ (TGF- $\beta$ ) is necessary for myofibroblast differentiation (Hinz, 2010). Impaired myofibroblast differentiation on stiff substrates is caused by inhibition of TGF- $\beta$ (Hinz 2010). TGF- $\beta$ is referred to as the major regulator of the myofibroblast differentiation and induces the expression of aSMA (Desmoulière et al., 1993). In addition, TGF- $\beta$ and its downstream effectors are thought to be the key inducer of fibrosis (Stempien-Otero et al., 2016; Meng et al., 2016). The TGF- $\beta$-signalling is rather complex and is regulated via Smad-dependent, canonical pathways or Smad-independent, non-canonical pathways (Zhang, 2009; Meng et al., 2016). 
Once activated, the homodimer form of TGF- $\beta$ binds to the TGF- $\beta$ receptor 2 (TGFR2) and thereby activates the TGF- $\beta$ receptor 1 (TGFR1). This results in the phosphorylation of the effector proteins Smad2 and Smad3, which form a complex with Smad4. The complex translocates into the nucleus, where Smad3 induces the transcription of genes activating the myofibroblast programme (Meng et al., 2016). In addition to the described Smad-dependent pathway, TGF- $\beta$ also induces Rho GTPase signalling, mitogen-activated protein kinase (MAPK) pathways and phosphatidylinositol 3 (PI-3)-kinase-Akt signalling (Zhang, 2009; Beier and Loeser, 2010; Carthy, 2018). Rho GTPases downstream signalling is further involved in the myocardin-related transcription factor (MRTF) / serum response factor (SRF) pathway, the key inducer for the myofibroblast programme and fibrosis (Small, 2012).

The reorganisation of the actin cytoskeleton represents the most important step of myofibroblast differentiation, leading to stress fiber formation and further to the contractile phenotype. Besides the mechanical forces, myofibroblasts also contribute to tissue remodelling by synthesising ECM components, such as collagens and the fibronectin splice variant extra domain-A (ED-A) (Hinz, 2007). Once the tissue is successfully repaired, myofibroblasts undergo apoptosis or remain in the scarred tissue (Willems et al., 1994; Desmoulière et al., 1995). Reversible myofibroblast differentiation resulting in a quiescent fibroblast has been considered in the literature (Hecker et al., 2011; Darby et al., 2014). However, the detailed mechanisms of this are still unknown.

\subsubsection{Tissue hypoxia and fibrosis}

Dysfunction of the complex myofibroblast differentiation signalling network can cause pathological conditions such as excessive scarring, fibrosis, as well as tissue and organ dysfunction (Tomasek et al., 2002; Hinz et al., 2012). The essential factors that promote excessive scarring after wound repair still need to be understood, however hypoxia has been suggested to play a critical role in myofibroblast dysfunction (Kischer et al., 1982; Darby and Hewitson, 2016). Normal wound healing can be divided into three major processes: inflammation, proliferation and tissue remodelling (Singer and Clark, 1999; Darby et al., 2014).

Oxygen plays a crucial role for normal wound healing. Tissue injury causes a sudden loss of perfusion, hence a lack of oxygen and nutrient supply. Wound healing proceeds under hypoxia (Darby et al., 2014). The HIF pathway activates the transcription of genes important for the inflammatory response, restoration of the vascularisation and the recovery of normoxia (Hong et al., 2014). Studies on HIF-1 deficient mice show hindered dermal wound healing due to delayed myofibroblast differentiation (Musyoka et al., 2013). Polymorphisms in the HIF-1a gene have been reported to be involved in systemic sclerosis, a connective tissue 
disease, within the European Caucasian population (Wipff et al., 2009). In physiological conditions, successful tissue repair leads to the decrease of aSMA and completion of the myofibroblast-mediated contraction (Desmoulière et al., 1995). Progressing scar formation is accompanied by increased cell apoptosis, especially affecting the myofibroblast population in the restored tissue (Desmoulière et al. 1995). However, myofibroblasts in the heart are reported to remain in myocardial scars (Willems et al. 1994). In pathological disorders, the contractile activity of myofibroblast in fibrotic tissue proceeds, causing tissue deformation (Desmoulière et al., 1995).

Even though transient hypoxia is critical for the activation of genes necessary to repair the damaged tissue, persistent hypoxia is detrimental for the healing of ischemic wounds (Darby and Hewitson, 2016). It has been speculated, that overactive contraction in scarring disorders, like hypertrophic scars and keloids, leads to microvascular occlusion and thus to chronic hypoxia (Darby and Hewitson, 2016). Chronic HIF-1a activity, accompanied with constant increased profibrotic factors (such as TGF- $\beta$ ) has been associated with fibroproliferative disorders, such as keloids and sclerosis (Zhang et al., 2003; Distler et al., 2007; Darby and Hewitson, 2016). Taken together, these findings emphasise the important influence of hypoxia on fibrotic diseases, however the molecular link between tissue oxygenation (i.e. hypoxia) and myofibroblast differentiation is not fully understood.

\subsection{Rho GTPases}

\subsubsection{The Rho GTPase family}

Rho GTPases are part of the Ras-like superfamily of small GTPases and consist of 20 known members in mammals (Vega and Ridley, 2008). These are divided into eight subgroups based on their shared amino-acid-sequence identity (Fig. 4) (Vega and Ridley, 2008). Ras-like proteins are found to be highly conserved among eukaryotes (Boureux et al., 2007). One of the biggest subfamilies of the Ras-like GTPases is the Rho family, which includes the well studied members RhoA (Ras homolog gene family member A), Rac1 (Ras-related C3 botulinum toxin substrate 1) and Cdc42 (Cell division control protein 42 homolog) (Tcherkezian and Lamarche-Vane, 2007; Heasman and Ridley, 2008). The members of the Rho family are small proteins, consisting of 190-250 amino acid residues including the GTPase domain plus $\mathrm{N}$ - and C-terminal extensions (Wennerberg and Der, 2004). The GTPase domain consists of a Rho insert domain, which is characteristic of the Rho family (Valencia et al., 1991; Wennerberg and Der, 2004). The Rho GTPases family members RhoA, RhoB and RhoC share a high amino acid sequence identity (87\%) and form the RhoA-related subfamily (Wennerberg and Der, 2004; Vega and Ridley, 2018). Furthermore, 
the RhoGTPase family can be divided into typical Rho GTPases and atypical Rho GTPases. Typical Rho GTPases, like, RhoA, Rac1 and Cdc42 are regulated by GTPase-activating proteins (GAPs) and guanine nucleotide-exchange factors (GEFs), whereas atypical Rho GTPases, like RhoE and RhoU, are regulated by phosphorylation, protein stability and gene expression (Heasman and Ridley, 2008).

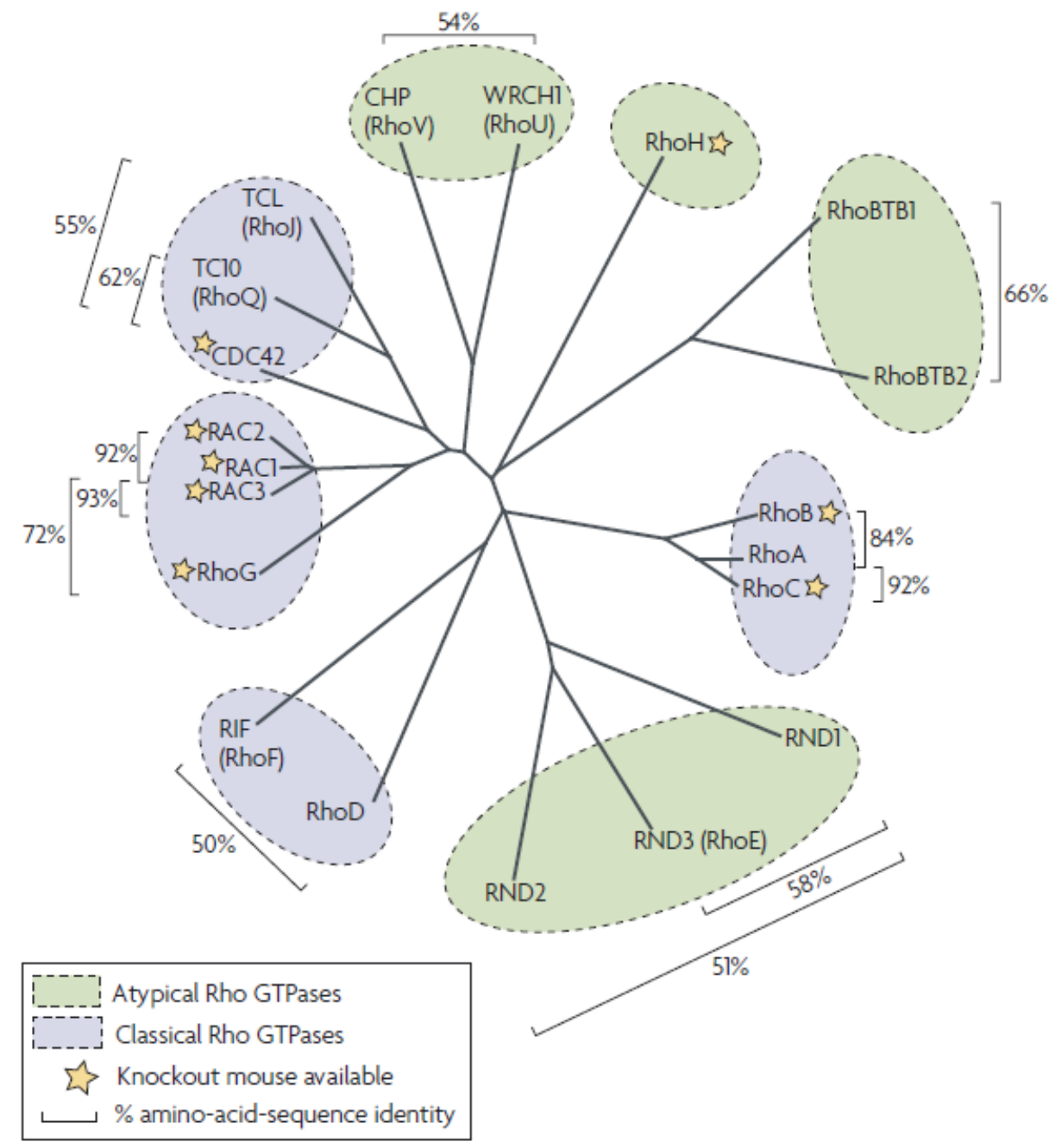

Figure 4: The Rho GTPase family. The phylogenetic tree is based on the shared amino-acid sequence identity of the shown Rho GTPases. The 20 members of the Rho GTPase family can be divided into eight subfamilies. Furthermore, the family members are assigned to atypical and classical Rho GTPases due to their mode of regulation. The figure is taken from Heasman and Ridley (2008). 


\subsubsection{The regulation of Rho GTPases}

Typical Rho GTPase switch between an active GTP-bound state and an inactive GDP-bound state (Fig. 5). Three proteins regulate this cycle: GEFs (Rossman et al., 2005), GAPs (Tcherkezian and Lamarche-Vane, 2007), and guanine nucleotide-dissociation inhibitors (GDIs) (Dovas and Couchman, 2005). GEFs catalyse the exchange of GDP to GTP, thus activate the Rho GTPases. GAPs stimulate the GTP hydrolysis, leading to the conversion to the inactive GDP-bound state (Vega and Ridley, 2008).

Both active and inactive forms of Rho GTPases can interact with membranes via posttranscriptional C-terminal modification (Bishop and Hall, 2000). GDIs are involved in the stabilisation of the GDP-bound state, maintaining the inactive Rho GTPases in the cytoplasm, preventing interaction with the membrane and the exchange of GDP to GTP (Olofsson, 1999; Bishop and Hall, 2000; Tcherkezian and Lamarche-Vane, 2007). In addition to this cycling regulation, it is known that Rho GTPases are also directly regulated by phosphorylation and ubiquitination (Lang et al., 1996; Wang et al., 2002). Activated Rho GTPases can activate downstream effectors, such as kinases, to induce a specific cellular response and behaviour (Vega and Ridley, 2008). RhoGTPases are involved in many cellular regulatory mechanisms, like the remodelling of the actin cytoskeleton, cell growth control, membrane trafficking and transcriptional activation (Villalonga and Ridley, 2006; Ridley, 2006).

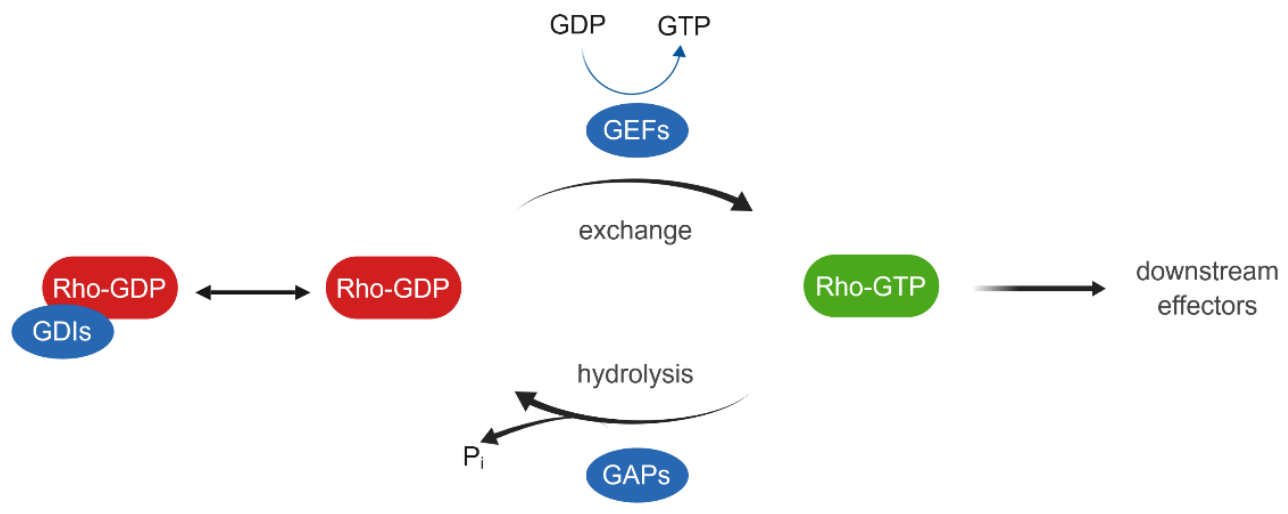

Figure 5: Schematic of the Rho GTPase regulation. Rho GTPases cycle between an inactive, GDP-bound conformation and an active, GTP-bound conformation. GTPase-activating proteins (GAPs) catalyse the hydrolysis of the GTP to the GDP-bound state. Inactive Rho GTPases can be sequestered in the cytoplasm by guanine nucleotide-dissociation inhibitors (GDIs). The activation of Rho GTPases is regulated by guanine nucleotide-exchange factors (GEFs), which promote the exchange of GDP to GTP. Once activated, Rho-GTP can regulate cell responses through downstream effectors. 


\subsubsection{The Rho family member RhoA}

The ubiquitously expressed Rho family member RhoA was the first isoform discovered in the 1980s while studying ras genes in Aplysia (Madaule and Axel, 1985). RhoA shares similarity with the isoforms RhoB and RhoC. Although they are similar, they differ in their expression profiles, cellular localisation and cellular function. RhoA is mainly responsible for actinmyosin contractility and actin stress fiber formation, whereas RhoB is involved in cell survival and cytokine trafficking and RhoC plays an important role in cell locomotion (Wheeler and Ridley, 2004). The main characteristic of Rho GTPases, the regulation of stress fibers, was first introduced by Chardin and colleagues through studies on Clostridium botulinum C3 toxin, a Rho inhibitor (Chardin et al., 1989). Treating cells with the toxic exoenzyme Clostridium botulinium C3 resulted in dissembled stress fibres due to the toxin's characteristic ADPribosylation of Rho GTPases (Chardin et al., 1989). This highlights the crucial role of Rho in the regulation of the actin cytoskeleton (Chardin et al., 1989). The important role of RhoA in stress fiber formation was further demonstrated by microinjection of RhoA into fibroblasts, resulting in excessive stress fiber formation (Paterson et al., 1990).

The functional role of RhoA was identified through mutant overexpression studies and Rho inhibitor experiments in vitro, which however may evoke off-target effects affecting other Rho GTPases (Zhou and Zheng, 2013). Whereas genetic ablation of RhoB (Liu et al., 2001) and RhoC (Hakem et al., 2005) has no effect on normal mouse development, the role of RhoA in vivo is less understood (Jackson et al., 2011). A knockout mouse model of RhoA is not available (Vega and Ridley, 2007). However, studies on chicken embryo development have revealed that loss of basal RhoA activity results in the disruption of epithelial cell-basement membrane interaction and hence in a disturbed epithelial-mesenchymal transition (Nakaya et al., 2008). These findings imply that RhoA is the most important member of the Rho subfamily.

\subsubsection{RhoA downstream signalling and its role in actin reorganisation}

The actin cytoskeleton is essential for a wide range of cellular processes, including cell morphology, cell migration and cell division (Hall, 1998). Cellular actin exists as monomeric globular actin (G-actin) and filamentous actin (F-actin). The transition of G-actin to F-actin is mediated by ATP to ADP hydrolysis. This leads to an actin treadmilling mechanism where monomeric actin attaches in the ATP-bound state to the fast growing, barbed $(+)$ end of the actin filaments, whereas actin dissembles at the pointed (-) end in an ADP-bound state (Pollard, 1986; Carlier, 1990; Lee and Dominguez, 2010). Actin dynamics are characterised by 
rapid turnover of F-actin (Riento and Ridley, 2003; Lee and Dominguez, 2010). RhoA mediates actin polymerisation by multiple effectors, among them the Rho-associated protein kinase (ROCK) and the mammalian diaphanous-related (mDia) formin pathways (Bishop and Hall, 2000; Olson and Nordheim, 2010). ROCK phosphorylates several proteins that are involved in the assembly and contraction of actin filaments, such as LIM kinase (LIMK) (Riento and Ridley, 2003). This phosphorylation enables LIMK to inhibit the actin-binding and depolymerizing protein cofilin via phosphorylation (Maekawa et al., 1999; Riento and Ridley, 2003). Inactiviation of cofilin induces the formation and stabilisation of actin filaments (Barbacid, 1987; Arber et al., 1998; Bishop and Hall, 2000; Bernard, 2007).

In addition, ROCK regulates actin-myosin interaction (Bishop and Hall, 2000). The contractility of non-muscle cells is controlled by the phosphorylation of the myosin light chain (MLC) of myosin II (Amano et al., 1996). The phosphorylation of MLC is regulated by the calciumdependent MLC kinase (MLCK) and the MLC phosphatase (MLCP) (Riento and Ridley, 2003). ROCK is known to phosphorylate MLC (Amano et al., 1996). ROCK also interacts with the myosin-binding subunit (MBS) of the MLCP (Riento and Ridley, 2003). Phosphorylation of MBS by ROCK results in MLCP inactivity accompanied by enhanced phosphorylation of MLC and consequently increased actomyosin assembly and enhanced cell contractility (Kimura et al., 1996; Bishop and Hall, 2000; Riento and Ridley, 2003).

Besides ROCK, mDia can also promote actin assembly downstream of active RhoA. When activated by RhoA, mDia regulates actin polymerisation at the barbed end of actin filaments. The formation of stress fibers requires the concerted activation of both ROCK and mDia as both dominant negative mutant experiments of either ROCK or mDia individually resulted in suppression of stress fibers and focal adhesion formation (Nakano et al., 1999). The Rhomediated G-actin to F-actin turnover (via ROCK or $\mathrm{mDia}$ ) also links actin dynamics to gene transcription (Hill et al., 1995; Miralles et al., 2003). G-actin binds MRTF and sequesters it in the cytoplasm (Miralles et al., 2003). Actin polymerisation frees the MRTF from G-actin and promotes the translocation of MRTF into the nucleus. In the nucleus, MRTF activates SRF, which is bound to the serum response element (SRE). This consequently activates the transcription of SRF target genes such as aSMA and Tagln, that are involved in the myofibroblast programme and fibrosis (refer to chapter 1.3.1 and 1.3.2) (Small, 2012). 


\subsubsection{The Rho GTPase activating protein ArhGAP29}

Since the first discovery of a RhoGAP by Garrett and colleagues three decades ago, the family of known RhoGAPs continuously grows (Garrett et al., 1989). Approximately 59 to 70 RhoGAP domain proteins are encoded by the human genome (Tcherkezian and LamarcheVane, 2007). The number of known RhoGAPs exceeds the number of Rho GTPases that they control (Lamarche and Hall, 1994; Tcherkezian and Lamarche-Vane, 2007). The reason for this is not apparent, however over the decades the scientific community has provided several possible explanations (Tcherkezian and Lamarche-Vane, 2007). Most likely, RhoGAPs do not regulate one specific Rho GTPase, but they might also act as a scaffolding protein to integrate signals from a number of pathways (Tcherkezian and Lamarche-Vane, 2007).

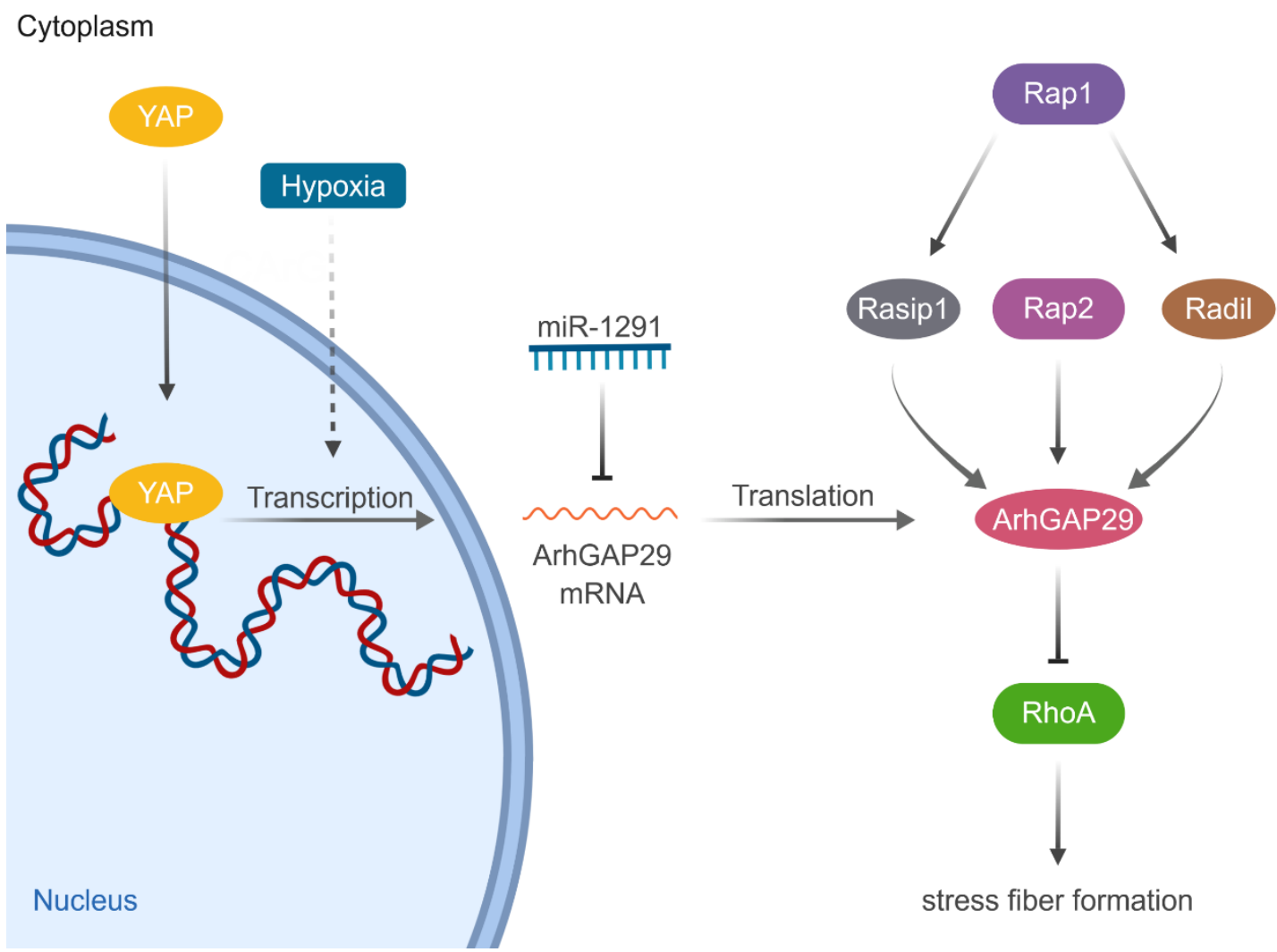

Figure 6: Schematic overview of the ArhGAP29 regulatory pathway. YAP (yes-associated protein) can promote the transcriptional activation of ArhGAP29. The microRNA (miR)-1291 is able to inhibit ArhGAP29 mRNA. ArhGAP29 protein levels can be regulated by Ras-related GTPase Rap1 effectors Rasip (ras-interacting protein) 1 and Radil (ras-association and dilute domain-containing protein) pathways. In addition, ArhGAP29 acts as an effector of Ras-related GTPase Rap2. ArhGAP29 negatively regulates RhoA activity by stimulating GTP hydrolysis. Active RhoA and its downstream effectors are involved in the formation of actin stress fibers. Hypoxic regulation of ArhGAP29 is suggested; however, the molecular details how hypoxia regulates ArhGA29 expression remains to be elucidated (dashed arrow). 
ArhGAP29 is a $142 \mathrm{kDa}$ protein that was originally named PARG1 (PTPL1-associated RhoGAP 1) because of its association with the intracellular protein-tyrosine phosphatase (PTP) PTPL1 (Saras et al., 1997). ArhGAP29 is widely expressed in many cell types and tissues, most notably in heart and skeletal muscle (Saras et al., 1997). ArhGAP29 contains four domains: a N-terminal ZPH (ZK66.91a and PARG homology) region and a central cysteine rich region, which are responsible for protein-protein interactions, the Rho GTPase domain and a small C-terminal region that interacts with PTPL1 (Saras et al., 1997; Myagmar et al., 2005; Leslie et al., 2012). The transcriptional co-activator yes-associated protein (YAP), a negative regulator of the Hippo pathway, is reported to promote ArhGAP29 expression (Fig. 6) (Qiao et al., 2017). Furthermore, hypoxia induces the expression of ArhGAP29 mRNA and protein as observed by J. Peters (laboratory of Prof. Katschinski). In contrast, the microRNA (miR)-1291 suppresses ArhGAP29 expression that is further involved in endometrial fibrosis (Xu et al., 2017). ArhGAP29 was identified as an effector of Ras-related GTPase Rap2 (Meng et al., 2018). In addition, ArhGAP29 is mediated by the interaction with ras-interacting protein (Rasip) 1 and ras-association and dilute domain-containing protein (Radil), as an effector of the Ras-related GTPase Rap1 (Xu et al., 2011; Post et al., 2013). Through its association with Rap1 and Rap2, ArhGAP29 is involved in endothelial barrier function and vascular tubulogenesis (Xu et al., 2011; Post et al., 2013; Post et al., 2015; Barry et al., 2016).

ArhGAP29 has a strong activity towards Rho and a weaker activity towards Rac1 and Cdc42 (Saras et al., 1997; van Buul et al., 2014). Thus, it is not surprising that alterations in ArhGAP29 expression and activity result in changed RhoA/ROCK signalling, and modulation of actin cytoskeleton mediated cellular functions (refer to chapter 1.4.3). Endothelial cells deficient in ArhGAP29 show increased RhoA/ROCK/myosin II activity resulting in a disorganised actin cytoskeleton, increased stress fiber formation, disturbed adhesions and a defected lumen formation (Xu et al., 2011). Consequently, ArhGAP29 influences many physiological and pathological events. For example, ArhGAP29 is known for its role in endothelial adhesion, spreading and polarisation in vascular lumen formation as well as in endothelial tubulogenesis (Xu et al., 2011; Post et al., 2013; van Buul et al., 2014).

In vivo studies on mice revealed a crucial role for ArhGAP29 to ensure embryonal development, as knockout of ArhGAP29 in epiblasts cells and loss of function mutations result in embryonic lethality (Barry et al., 2016; Paul et al., 2017). A common birth defect, the nonsyndromic cleft lip and / or palate (NSCL/P) is reported to correlate with several mutations of ArhGAP29 in humans (Leslie et al., 2012; Butali et al., 2014; Chandrasekharan and Ramanathan, 2014; Paul et al., 2017; Liu et al., 2017). The mutations of ArhGAP29 associated 
with this congenital disability include functional non-coding variants, loss-of-function variants as well as point mutations (Savastano et al., 2017; Paul et al., 2017; Liu et al., 2017).

Taken together, ArhGAP29 is involved in a wide range of cellular and developmental processes due to its regulatory role on RhoA signalling. Therefore, it can be hypothesised that ArhGAP29 expression needs to be carefully controlled to ensure precisely regulation of cytoskeletal-mediated cellular mechanisms. 


\subsection{Aims of this doctoral thesis}

Myofibroblasts play a crucial role in wound healing and tissue remodelling. However, dysfunctional myofibroblast differentiation results in pathological conditions, such as fibrosis and organ dysfunction. Myofibroblast differentiation underlies a highly orchestrated interplay of microenvironmental stimuli, such as mechanical tension, cytokine signalling and tissue oxygenation. The intricate molecular machinery regulating this process remains unclear. Rho GTPases, particularly the Rho family member RhoA, are known to be the main regulators of actin cytoskeleton remodelling. Rho activity also induces gene expression essential for the myofibroblast differentiation programme. The myofibroblast differentiation is mediated by MRTF-A/SRF signalling, one of the key inducers of the fibrotic response.

Preliminary research by the laboratory of Prof. Katschinski revealed the hypoxic induction of the Rho GTPase activating protein ArhGAP29 in diverse cell types, including primary fibroblasts and ischemic cardiac tissue. Furthermore, J. Peters (laboratory of Prof. Katschinski) established a knockdown of ArhGAP29 in L929 cells, which resulted in changes in cell morphology and actin cytoskeleton modulation. These findings suggest that ArhGAP29 is involved in fine-tuning RhoA activity and MRTF/SRF signalling in hypoxia. Thus, analysing the function of ArhGAP29 in hypoxia would further the understanding of myofibroblast differentiation and myofibroblast-related diseases, such as fibrosis.

In this doctoral thesis, the impact of oxygenation on the myofibroblast differentiation programme and the role of ArhGAP29 on the RhoA-MRTF-A/SRF signalling pathway in hypoxia were addressed through the following aims:

1. To investigate the effect of hypoxia on the myofibroblast differentiation and contractile function in primary skin fibroblasts.

2. To investigate the effect of hypoxia on RhoA activity.

3. To analyse the role of ArhGAP29 on regulating RhoA activity and on remodelling of the actin cytoskeleton in hypoxia.

4. To reveal the downstream effects of ArhGAP29 induction in hypoxia on MRTF-A/SRF signalling.

5. To test if the knockdown of ArhGAP29 in primary fibroblasts has an impact on myofibroblast differentiation in hypoxia and if regulating ArhGAP29 expression could be a potential therapeutic strategy for treatment of ischemia-induced tissue remodelling. 


\section{Material and Methods}

\subsection{Animals}

For primary cell isolation, 6-12 weeks old wildtype mice (Mus musculus, C57BL/6J) were purchased from Charles River, Germany or the central animal facility at the University Medical Center, Göttingen. Animals were kept according to animal welfare regulations.

\subsection{Cell lines}

Cell lines used for the experiments are described in Table 1. L929 cells were purchased from the American Type Culture Collection (ATCC, Manassas, VA, USA). C2C12 cells were provided by S. Rohrbach (Institute of Physiology, Justus Liebig University Giessen, Germany). All MEF cell lines were kindly provided by R.S. Johnson (Department of Physiology, University of Cambridge, U.K).

Table 1: Cell lines

\begin{tabular}{|c|c|}
\hline Cell line & Origin \\
\hline C2C12 & murine myoblasts \\
\hline HEK293T & human embryonic kidney cells \\
\hline L929 & murine fibroblasts, connective tissue \\
\hline L929 ArhGAP29 kd & $\begin{array}{l}\text { murine fibroblasts, connective tissue } \\
\text { ArhGAP29 knockdown (Vogler et al., 2013) }\end{array}$ \\
\hline L929 shHIF-1 $\alpha$ & $\begin{array}{l}\text { murine fibroblasts, connective tissue } \\
\text { HIF-1a knockdown (Vogler et al., 2013) }\end{array}$ \\
\hline L929 shco & $\begin{array}{l}\text { murine fibroblasts, connective tissue } \\
\text { non-targeting shRNA control (Vogler et al., } \\
2013 \text { ) }\end{array}$ \\
\hline MEF $(\mathrm{MEF}+/+)$ & $\begin{array}{l}\text { mouse embryonic fibroblasts (Ryan et al., } \\
2000 \text { ) }\end{array}$ \\
\hline MEF HIF-1a-/- (MEF -/-) & $\begin{array}{l}\text { mouse embryonic fibroblasts derived from } \\
\text { HIF-1a null embryos (Ryan et al., 2000) }\end{array}$ \\
\hline
\end{tabular}




\subsection{Cell culture media and solutions}

Purchased cell culture medium, supplements and supplies are shown in Table 2.

The components of different cell culture media and solutions used for experiments are indicated in Table 3.

Table 2: Cell culture medium, supplements and supplies

\begin{tabular}{|l|l|l|}
\hline \multicolumn{1}{|c|}{ Product } & \multicolumn{1}{|c|}{ Manufacturer } & \multicolumn{1}{c|}{ Catalogue number } \\
\hline DMEM, high glucose & PAN $^{\mathrm{TM}}$ Biotech & P04-03590 \\
\hline DMEM / F12 (1:1) & PAN $^{\mathrm{TM}}$ Biotech & P04-41150 \\
\hline $\begin{array}{l}\text { Good) } \\
\text { Miltrated Bovine Serum (FBS }\end{array}$ & PAN $^{\mathrm{TM}}$ Biotech \\
$\begin{array}{l}\text { Non-Essential Amino Acids } \\
\text { (MEM-NEAA) }\end{array}$ & PAN $^{\mathrm{TM}}$ Biotech & P40-37500 \\
\hline Opti-MEM
\end{tabular}

Table 3: Cell culture medium components and solutions

\begin{tabular}{|l|l|}
\hline \multicolumn{1}{|c|}{ Medium / solution } & \multicolumn{1}{|c|}{ Ingredients } \\
\hline DMEM culture medium & DMEM, high glucose \\
& $10 \% \mathrm{FBS}$, heat inactivated \\
& $50 \mathrm{U} / \mathrm{ml}$ Penicillin \\
& $50 \mu \mathrm{g} / \mathrm{ml}$ Streptomycin \\
\hline Primary skin fibroblast culture medium & DMEM / F12 (1:1) \\
& $10 \% \mathrm{FBS}$, heat inactivated \\
& $1 \% \mathrm{MEM}$ NEAA \\
& $50 \mathrm{U} / \mathrm{ml}$ Penicillin \\
& $50 \mu \mathrm{g} / \mathrm{ml}$ Streptomycin \\
\hline Starvation medium & DMEM culture medium or primary fibroblast \\
& culture medium with supplements and re- \\
& duced serum concentration $(0.1 \%$ FBS, heat \\
& inactivated $)$ \\
\hline Trypsin/EDTA solution & $1 \mathrm{mM}$ EDTA in Trypsin \\
\hline
\end{tabular}




\subsection{Chemicals}

Chemicals used for the experiments are listed in Table 4.

Table 4: Chemicals

\begin{tabular}{|c|c|c|}
\hline Product & Manufacturer & Catalogue number \\
\hline $\begin{array}{l}\text { 2,3-Butanedione Monoxime } \\
\text { (BDM) }\end{array}$ & Cell Biolabs, Inc. & 20105; CBA-201 \\
\hline $\begin{array}{l}\text { 4-(2-hydroxyethyl)-1- } \\
\text { piperazineethanesulfonic acid } \\
\text { (HEPES) }\end{array}$ & PAN $^{T M}$ Biotech & P05-01100 \\
\hline $\begin{array}{l}\text { 4',6-diamidino-2-phenylindole } \\
\text { (DAPI) }\end{array}$ & Sigma-Aldrich & D9542-10MG \\
\hline Acetic acid & Carl Roth & 3738.5 \\
\hline Agar-agar & Carl Roth & 5210.2 \\
\hline Agarose Broad Range & Carl Roth & T846.3 \\
\hline $\begin{array}{l}\text { Albumine Bovine Fraction V } \\
\text { (BSA) }\end{array}$ & Applichem & A1391.0500 \\
\hline Ammonium persulfate (APS) & Carl Roth & 9592 \\
\hline Ampicillin Sodium salt & Carl Roth & K029.2 \\
\hline$\beta$-Mercaptoethanol & Carl Roth & 4277.1 \\
\hline $\begin{array}{l}\text { Bromophenol blue sodium } \\
\text { salt }\end{array}$ & Carl Roth & A512.1 \\
\hline Chloroform & Carl Roth & 3313.1 \\
\hline Coumaric acid & Sigma-Aldrich & C-9008 \\
\hline $\begin{array}{l}\text { Dimethyloxalylglycine } \\
\text { (DMOG) }\end{array}$ & Enzo Biochem & BML-E1347-0050 \\
\hline Dimethyl sulfoxide (DMSO) & Thermo Fisher Scientific & F-515 \\
\hline $\begin{array}{l}\text { Di-Sodium hydrogen phos- } \\
\text { phate dihydrate } \\
\left(\mathrm{Na}_{2} \mathrm{HPO}_{4} \times 2 \mathrm{H}_{2} \mathrm{O}\right)\end{array}$ & Carl Roth & 4984.1 \\
\hline Dithiothreitol (DTT) & Carl Roth & 6908.1 \\
\hline $\begin{array}{l}\text { Ethylenediaminetetraacetic } \\
\text { acid (EDTA) }\end{array}$ & Carl Roth & 8043.2 \\
\hline Ethanol & Carl Roth & 9065.4 \\
\hline $\begin{array}{ll}\text { Fluoromount }^{\mathrm{TM}} & \text { Aqueous } \\
\text { Mounting Medium } & \end{array}$ & Sigma-Aldrich & F4680 \\
\hline Gene Ruler DNA ladder, 1kB & Thermo Fisher Scientific & SM0311 \\
\hline
\end{tabular}




\begin{tabular}{|c|c|c|}
\hline Glutathione Sepharose $^{\mathrm{TM}}$ & GE Healthcare & $17-5132-01$ \\
\hline Glycerol & Carl Roth & 3783.2 \\
\hline Glycine & Carl Roth & 3908.2 \\
\hline $\begin{array}{l}\text { Hexadimethrine } \quad \text { bromide } \\
\text { (Polybrene) }\end{array}$ & Th. Geyer & H9268 \\
\hline Hydrogen peroxide $\left(\mathrm{H}_{2} \mathrm{O}_{2}\right)$ & Sigma-Aldrich & H1009 \\
\hline Isopropanol & Carl Roth & 6752.4 \\
\hline $\begin{array}{l}\text { Isopropyl- } \beta-D- \\
\text { thiogalactopyranoside (IPTG) }\end{array}$ & Fermentas & R0392 \\
\hline Lenti- $\mathrm{X}^{\mathrm{TM}}$ Concentrator & TaKaRa & 631231 \\
\hline Lipofectamine $^{\circledR} 2000$ & Invitrogen & $11668-019$ \\
\hline Luminol & Carl Roth & 4203.1 \\
\hline Methanol & Carl Roth & 4627.5 \\
\hline $\begin{array}{l}\text { Monopotassium phosphate } \\
\left(\mathrm{KH}_{2} \mathrm{PO}_{4}\right)\end{array}$ & Carl Roth & 6875.1 \\
\hline Nonidet $^{(\Theta}$ P40 (NP-40) & Sigma-Aldrich & $74385-1 \mathrm{~L}$ \\
\hline Paraformaldehyde & Carl Roth & 0335.1 \\
\hline $\begin{array}{l}\text { PageRuler }{ }^{\mathrm{TM}} \text { Prestained Pro- } \\
\text { tein Ladder }\end{array}$ & Thermo Fisher Scientific & 221616 \\
\hline $\begin{array}{l}\text { Phenylmethane sulfonyl fluo- } \\
\text { ride (PMSF) }\end{array}$ & Carl Roth & 6367.1 \\
\hline $\begin{array}{l}\text { Protease Inhibitor Cocktail } \\
\text { Tablet cOmplete }{ }^{\mathrm{TM}} \text { Mini, } \\
\text { EDTA-free }\end{array}$ & Roche & 04693124001 \\
\hline $\begin{array}{l}\text { Protein Assay Dye Reagent } \\
\text { Concentrate }\end{array}$ & BioRad & $500-0006$ \\
\hline Potassium chloride $(\mathrm{KCl})$ & Carl Roth & 6787.1 \\
\hline Ponceau & Carl Roth & P7170 \\
\hline Puromycin & Gibco & A11138-03 \\
\hline RNase-free water & Thermo Fisher Scientific & R0581 \\
\hline $\begin{array}{l}\text { Roentogen liquid, X-ray de- } \\
\text { veloper solution }\end{array}$ & Tetenal & 103482 \\
\hline $\begin{array}{l}\text { Roentogen Superfix, X-ray } \\
\text { fixer solution }\end{array}$ & Tetenal & 103655 \\
\hline Rotiphorese $^{\circledR}$ Gel 30 & Carl Roth & 3029.2 \\
\hline Roti Safe Gel Stain & Carl Roth & 3865.1 \\
\hline Skim milk powder & AppliChem & A0830.0500 \\
\hline
\end{tabular}




\begin{tabular}{|c|c|c|}
\hline Sodium chloride $(\mathrm{NaCl})$ & Carl Roth & 9265.2 \\
\hline $\begin{array}{l}\text { Sodium dodecyl sulfate } \\
\text { (SDS) }\end{array}$ & Carl Roth & 4360.2 \\
\hline Sodium fluoride (NaF) & Sigma-Aldrich & $87920-100 G$ \\
\hline $\begin{array}{l}\text { Sodium orthovanadate } \\
\left(\mathrm{Na}_{3} \mathrm{VO}_{4}\right)\end{array}$ & Sigma-Aldrich & S508-50G \\
\hline $\begin{array}{l}\text { Tetramethylethylenediamine } \\
\text { (TEMED) }\end{array}$ & Carl Roth & 2367.3 \\
\hline TGF- $\beta 1$, human & PeproTech & 100-21C-10UG \\
\hline $\begin{array}{l}\text { Tris(hydroxymethyl)- } \\
\text { aminomethane (TRIS) }\end{array}$ & Carl Roth & 5429.3 \\
\hline Triton X-100 & Carl Roth & 3051.4 \\
\hline TRIzol $^{\circledR}$ & $\begin{array}{l}\text { Thermo Fisher Scientific } \\
\text { (Ambion) }\end{array}$ & 15596018 \\
\hline Tween $^{\circledR} 20$ & Carl Roth & 91271 \\
\hline
\end{tabular}

\subsection{Buffers and solutions}

The components of buffers and solutions used for experiments are given in Table 5.

Table 5: Buffers and solutions

\begin{tabular}{|c|c|}
\hline Buffer / solution & Ingredients \\
\hline \multicolumn{2}{|c|}{ Immunofluorescence } \\
\hline Blocking buffer & $1 \%$ BSA in PBS \\
\hline Cell permeabilisation buffer & $0.2 \%$ Triton $\mathrm{X}-100$ in PBS \\
\hline DAPI staining solution & $5 \mathrm{mg}$ DAPI in $5 \mathrm{ml} \mathrm{H}_{2} \mathrm{O}$ \\
\hline \multicolumn{2}{|c|}{ Isolation of primary skin fibroblasts } \\
\hline Digestion buffer & $\begin{array}{l}400 \mathrm{U} / \mathrm{ml} \text { Collagenase II in primary fibroblast } \\
\text { culture medium }\end{array}$ \\
\hline
\end{tabular}




\begin{tabular}{|c|c|}
\hline \multicolumn{2}{|c|}{ Rho GTPase activity assay } \\
\hline $\begin{array}{l}\text { Bacterial lysis and washing buffer } \\
\text { (STE-PMSF buffer) }\end{array}$ & $\begin{array}{l}10 \mathrm{mM} \text { TRIS, pH } 8.0 \\
150 \mathrm{mM} \mathrm{NaCl} \\
1 \mathrm{mM} \text { EDTA } \\
1 \mathrm{mM} \mathrm{PMSF} \\
\text { in } \mathrm{ddH}_{2} \mathrm{O}\end{array}$ \\
\hline Cell lysis buffer & $\begin{array}{l}25 \mathrm{mM} \text { HEPES, pH } 7.5 \\
150 \mathrm{mM} \mathrm{NaCL} \\
10 \mathrm{mM} \mathrm{MgCl}_{2} \\
1 \% \mathrm{NP}-40 \\
1 \mathrm{mM} \text { EDTA } \\
10 \% \text { Glycerol }\end{array}$ \\
\hline $1 \times \mathrm{Mg}^{2+}$ buffer & $\begin{array}{l}5 \times \mathrm{Mg}^{2+} \text { buffer } \\
25 \mathrm{mM} \mathrm{NaF} \\
1 \mathrm{mM} \mathrm{Na}_{3} \mathrm{VO}_{4} \\
100 \mu \mathrm{gMSF} \\
10 \% \text { Glycerol } \\
1 \text { Protease Inhibitor Cocktail Tablet } \\
\text { (per } 10 \mathrm{ml} \text { buffer volume) }\end{array}$ \\
\hline $5 \times \mathrm{Mg}^{2+}$ buffer & $\begin{array}{l}125 \mathrm{mM} \text { HEPES, } \mathrm{pH} 7.5 \\
750 \mathrm{mM} \mathrm{NaCl} \\
5 \% \mathrm{NP}^{-40} \\
50 \mathrm{mM} \mathrm{MgCl}_{2} \\
5 \mathrm{mM} \mathrm{EDTA} \\
\text { in } \mathrm{ddH}_{2} \mathrm{O}\end{array}$ \\
\hline \multicolumn{2}{|c|}{ SDS-PAGE and Immunoblot } \\
\hline Cell lysis buffer & $\begin{array}{l}400 \mathrm{mM} \mathrm{NaCl} \\
1 \mathrm{mM} \text { EDTA } \\
10 \mathrm{mM} \text { TRIS/HCl pH } 8.0 \\
0.1 \% \text { Triton } \mathrm{X}-100 \\
1: 10 \text { Protease inhibitor mix }\end{array}$ \\
\hline Enhanced chemiluminescence solution (ECL) & $\begin{array}{l}100 \mathrm{mM} \text { TRIS/HCl, pH } 8.5 \\
90 \mathrm{mM} \text { Coumaric acid } \\
250 \mathrm{mM} \text { Luminol } \\
0.009 \% \mathrm{H}_{2} \mathrm{O}_{2}\end{array}$ \\
\hline Immunoblot blocking buffer & $5 \%$ Skimmed milk powder in 1x PBS \\
\hline
\end{tabular}




\begin{tabular}{|c|c|}
\hline Immunoblot transfer buffer & $\begin{array}{l}25 \text { mM TRIS } \\
192 \text { mM Glycine } \\
20 \% \text { Methanol }\end{array}$ \\
\hline Sample loading buffer (6x Laemmli) & $\begin{array}{l}100 \text { mM TRIS, pH } 6.8 \\
4 \% \text { SDS } \\
0.2 \% \text { Bromophenol blue } \\
20 \% \text { Glycerol } \\
5 \% \text {-mercaptoethanol }\end{array}$ \\
\hline Phosphate buffered saline (PBS) & $\begin{array}{l}137 \mathrm{mM} \mathrm{NaCl} \\
2.7 \mathrm{mM} \mathrm{KCl} \\
4.3 \mathrm{mM} \mathrm{Na}_{2} \mathrm{HPO}_{4} \times 7 \mathrm{H}_{2} \mathrm{O} \\
1.4 \mathrm{mM} \mathrm{KH}_{2} \mathrm{PO}_{4}, \mathrm{pH} 7.4\end{array}$ \\
\hline Ponceau S staining solution & $\begin{array}{l}0.1 \% \text { Ponceau } \\
5 \% \text { Acetic acid }\end{array}$ \\
\hline Protease inhibitor mix & $\begin{array}{l}1 \text { Protease Inhibitor Cocktail Tablet in } 1.5 \mathrm{ml} \\
\mathrm{ddH}_{2} \mathrm{O}\end{array}$ \\
\hline 5x SDS-PAGE running buffer & $\begin{array}{l}125 \mathrm{mM} \text { TRIS } \\
1.25 \mathrm{M} \text { Glycine } \\
0.5 \% \mathrm{SDS} \\
\text { in } \mathrm{ddH}_{2} \mathrm{O}, \mathrm{pH} 8.3\end{array}$ \\
\hline $\begin{array}{l}\text { TBS-T (TRIS-buffered saline with Tween-20 } \\
\text { washing buffer) }\end{array}$ & $\begin{array}{l}1 \mathrm{M} \text { TRIS, pH } 7.6 \\
5 \mathrm{M} \mathrm{NaCl} \\
10 \% \text { Tween-20 }\end{array}$ \\
\hline X-ray developer solution & 1:3.5 Roentogen liquid in $\mathrm{ddH}_{2} \mathrm{O}$ \\
\hline X-ray fixing solution & 1:2 Roentogen Superfix in $\mathrm{ddH}_{2} \mathrm{O}$ \\
\hline
\end{tabular}

\subsection{Enzymes}

Purchased enzymes are listed in Table 6.

Table 6: Enzymes

\begin{tabular}{|l|l|l|}
\hline \multicolumn{1}{|c|}{ Enzyme } & \multicolumn{1}{c|}{ Manufacturer } & \multicolumn{1}{c|}{ Catalogue number } \\
\hline Collagenase Type II & Biochrom & C2-22 \\
\hline Lysozyme & Sigma-Aldrich & L6876-1G \\
\hline $\begin{array}{l}\text { Rho Inhibitor I, } \\
\text { C3 Transferase }\end{array}$ & Cytoskeleton, Inc. & CT04 \\
\hline
\end{tabular}




\subsection{Kits}

Commercially available kits used for experiments are listed in Table 7.

Table 7: Kits

\begin{tabular}{|l|l|l|}
\hline \multicolumn{1}{|c|}{ Kit } & \multicolumn{1}{|c|}{ Manufacturer } & \multicolumn{1}{c|}{ Catalogue number } \\
\hline Cell Contraction Assay & Cell Biolabs, Inc. & CBA-201 \\
\hline $\begin{array}{l}\text { Dual-Luciferase }{ }^{\circledR} \text { Reporter } \\
\text { Assay System }\end{array}$ & Promega & E1910 \\
\hline First Strand cDNA Synthesis & Thermo Fisher Scientific & K1612 \\
\hline $\begin{array}{l}\text { SensiMix } \\
\text { Mix SYBR Lo-ROX }\end{array}$ & Bioline & QT6525-05 \\
\hline
\end{tabular}

\subsection{Antibodies}

Antibodies used for immunoblotting and immunostaining are listed in Tables 8 to 11 .

Table 8: Immunoblotting primary antibodies

\begin{tabular}{|l|l|l|l|l|}
\hline \multicolumn{1}{|c|}{ Antibody } & \multicolumn{1}{c|}{ Origin } & \multicolumn{1}{c|}{ Dilution } & Manufacturer & \multicolumn{1}{c|}{ Catalogue number } \\
\hline anti-ArhGAP29 & rabbit & $1: 2000$ & Novus & NBP-05989 \\
\hline anti-HIF-1a & rabbit & $1: 1000$ & Novus & NB100-449 \\
\hline anti-RhoA & rabbit & $1: 500$ & Cell Signaling & 67 B9 mAb\#2117 \\
\hline anti-Tubulin & rabbit & $1: 1500$ & abcam & ab6046 \\
\hline anti-Vinculin & mouse & $1: 10000$ & Sigma-Aldrich & V9264 \\
\hline
\end{tabular}

Table 9: Immunostaining primary antibody

\begin{tabular}{|l|l|l|l|l|}
\hline \multicolumn{1}{|c|}{ Antibody } & \multicolumn{1}{c|}{ Origin } & \multicolumn{1}{c|}{ Dilution } & Manufacturer & \multicolumn{1}{c|}{ Catalogue number } \\
\hline anti-aSMA & rabbit & $1: 500$ & Sigma-Aldrich & A2547 \\
\hline anti-MRTF-A & rabbit & $1: 200$ & $\begin{array}{l}\text { Kindly provided by Prof. G. Posern, Mar- } \\
\text { tin-Luther University, } \\
\text { Halle-Wittenberg, Germany }\end{array}$ \\
& & & \multicolumn{3}{|c}{} \\
\hline
\end{tabular}

Table 10: Immunoblotting secondary antibodies

\begin{tabular}{|l|l|l|l|l|}
\hline \multicolumn{1}{|c|}{ Antibody } & \multicolumn{1}{c|}{ Origin } & \multicolumn{1}{c|}{ Dilution } & Manufacturer & \multicolumn{1}{c|}{ Catalogue number } \\
\hline anti-mouse HRP & goat & $1: 1000$ & Santa Cruz & sc-2005 \\
\hline anti-rabbit HRP & goat & $1: 10000$ & Santa Cruz & sc-2004 \\
\hline
\end{tabular}


Table 11: Immunostaining secondary antibody

\begin{tabular}{|l|l|l|l|l|}
\hline \multicolumn{1}{|c|}{ Antibody } & \multicolumn{1}{c|}{ Origin } & \multicolumn{1}{c|}{ Dilution } & Manufacturer & Catalogue number \\
\hline anti-mouse FITC & goat & $1: 200$ & Sigma-Aldrich & F0257 \\
\hline anti-rabbit FITC & goat & $1: 200$ & Sigma-Aldrich & F0382 \\
\hline
\end{tabular}

\subsection{Conjugated fluorescent probes}

For F-actin staining, the phallotoxin phalloidin probe conjugated to fluorescent Alexa Fluor ${ }^{\mathrm{TM}}$ 594 or Texas Red ${ }^{\mathrm{TM}}-\mathrm{X}$ dye was used. Details are given in Table 12.

Table 12: Conjugated fluorescent probe

\begin{tabular}{|l|l|l|l|}
\hline \multicolumn{1}{|c|}{ Probe } & \multicolumn{1}{|c|}{ Dilution } & \multicolumn{1}{c|}{ Manufacturer } & Catalogue number \\
\hline $\begin{array}{l}\text { Alexa Fluor } \\
\text { Phalloidin } 594\end{array}$ & $1: 400$ & $\begin{array}{l}\text { Thermo Fisher } \\
\text { Scientific }\end{array}$ & A12381 \\
\hline $\begin{array}{l}\text { Texas Red } \\
\text { Phalloidin }-\mathrm{X}\end{array}$ & $1: 400$ & $\begin{array}{l}\text { Thermo Fisher } \\
\text { Scientific }\end{array}$ & T7471 \\
\hline
\end{tabular}

\subsection{0 qRT-PCR specific oligonucleotides}

Primers in Table 13 were designed specifically for the templates of interests with Primer3 and BLAST by NCBI for Mus musculus. Primers were purchased from Biomers.

Table 13: qRT-PCR specific-oligonucleotides

\begin{tabular}{|c|c|c|}
\hline Gene & Sequence $\left(5^{\prime}-3^{\prime}\right)$ & $\begin{array}{c}\text { Annealing } \\
\text { temperature }\end{array}$ \\
\hline \multirow[t]{2}{*}{ aSMA } & fw GCCAGTCGCTGTCAGGAACCC & \multirow[t]{2}{*}{$65^{\circ} \mathrm{C}$} \\
\hline & rev GCCAGCCAAGTCCAGACGCA & \\
\hline \multirow[t]{2}{*}{ ArhGAP29 } & fw ATCTGAGGCGAGTGGTGGAT & \multirow[t]{2}{*}{$58^{\circ} \mathrm{C}$} \\
\hline & rev AGCAGCTTGGGGCTTTTACA & \\
\hline \multirow[t]{2}{*}{ CTGF } & fw GTGTGCACTGCCAAAGATGGT & \multirow[t]{2}{*}{$58^{\circ} \mathrm{C}$} \\
\hline & rev GTCCGGATGCACTTTTTGCC & \\
\hline \multirow[t]{2}{*}{ Ms12 } & fw GAAGCTGCCAAGGCCTTAGA & \multirow[t]{2}{*}{$58^{\circ} \mathrm{C}$} \\
\hline & rev AACTGCAACCAACCACCTTC & \\
\hline \multirow[t]{2}{*}{ PHD3 } & fw GGCCGCTGTATCACCTGTAT & \multirow[t]{2}{*}{$58^{\circ} \mathrm{C}$} \\
\hline & rev TTCTGCCCTTTCTTCAGCAT & \\
\hline
\end{tabular}




\subsection{Bacteria culture material and medium}

The medium for bacteria culture are listed in Table 14.

Table 14: Bacteria culture material and medium

\begin{tabular}{|l|l|l|}
\hline \multicolumn{1}{|c|}{ Medium } & \multicolumn{1}{|c|}{ Ingredients } & \multicolumn{1}{c|}{ Catalogue number } \\
\hline LB-Agar (Luria/Miller) & Carl Roth & X969.2 \\
\hline LB-Medium (Luria/Miller) & Carl Roth & X968.2 \\
\hline
\end{tabular}

\subsection{Bacterial strains}

Following bacterial strains were used: E.coli Top $10 \mathrm{~F}$ - mcrA $\Delta$ (mrr-hsdRMS-mcrBC) f80lacZ $\Delta$ M15 $\Delta$ lacX74 deoR recA1 araD139 $\Delta$ (ara-leu)7697 galU galK rpsL endA1 nupG purchased from Invitrogen. In addition, BL21 was used to express pGEX-GST-RBDRhotekin, which was kindly provided by Prof. A. J. Ridley, King's College London, London, U.K.

\subsection{Plasmids}

Plasmids used for luciferase reporter gene activity, lentiviral packaging and genetic modification and RhoA activity assay are listed in Table 15.

Table 15: Plasmids

\begin{tabular}{|c|c|c|c|}
\hline \multirow{3}{*}{ 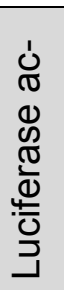 } & \multirow{3}{*}{$\stackrel{\gtrless}{\gtrless}$} & Plasmid & Origin \\
\hline & & pSRE.L & $\begin{array}{l}\text { Kindly provided by Dr. J. Mao and Dr D. Wu, } \\
\text { University of Rochester, Rochester, NY, USA }\end{array}$ \\
\hline & & pRL.TK & Promega \\
\hline \multirow[b]{3}{*}{ 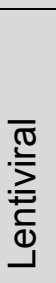 } & \multirow{3}{*}{ 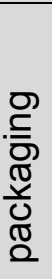 } & pLP1 & Invitrogen (Thermo Fisher Scientific) \\
\hline & & pLP2 & Invitrogen (Thermo Fisher Scientific) \\
\hline & & pLP-VSVG & Invitrogen (Thermo Fisher Scientific) \\
\hline \multirow{3}{*}{ 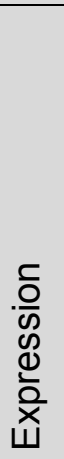 } & \multirow[b]{3}{*}{ 产 } & MRTF-A-GFP & $\begin{array}{l}\text { Kindly provided by Prof. G. Posern, } \\
\text { Martin-Luther University Halle-Wittenberg, Ger- } \\
\text { many }\end{array}$ \\
\hline & & $\begin{array}{l}\text { pLKO.1-puro ArhGAP29- } \\
\text { shRNA, TRCN0000023926 }\end{array}$ & Sigma-Aldrich \\
\hline & & $\begin{array}{l}\text { pLKO.1-puro non-targeting } \\
\text { shRNA, \#SHC002 }\end{array}$ & Sigma-Aldrich \\
\hline
\end{tabular}




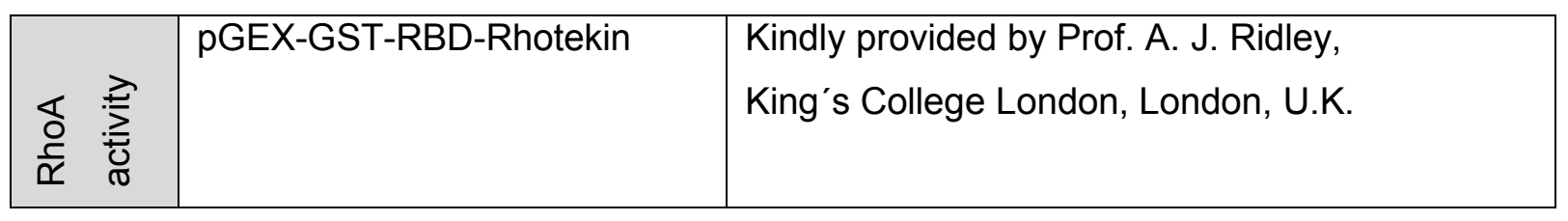

\subsection{Consumables}

All common laboratory consumables are listed in Table 16.

Table 16: Consumables

\begin{tabular}{|c|c|c|c|}
\hline Product & Type & Manufacturer & Catalogue number \\
\hline \multirow[t]{2}{*}{ Cell culture flask } & $25 \mathrm{~cm}^{2}$ & \multirow[t]{2}{*}{ Greiner Bio-One } & 690175 \\
\hline & $75 \mathrm{~cm}^{2}$ & & 658175 \\
\hline \multirow{3}{*}{$\begin{array}{l}\text { Cell culture } \\
\text { multiwell plate }\end{array}$} & 6-well & \multirow[t]{3}{*}{ Sarstedt } & 83.3920 \\
\hline & 12-well & & 83.3921 \\
\hline & 24-well & & 83.3922 \\
\hline \multirow[t]{4}{*}{ Cell culture dish } & $35 \times 10 \mathrm{~mm}$ & \multirow[t]{4}{*}{ Sarstedt } & 83.3900 .300 \\
\hline & $60 \times 15 \mathrm{~mm}$ & & 83.3901 \\
\hline & $100 \times 20 \mathrm{~mm}$ & & 83.3902 .300 \\
\hline & $150 \times 20 \mathrm{~mm}$ & & 83.3903 .300 \\
\hline $\begin{array}{l}\text { Cell strainer, } \\
\text { EASYstrainer }^{\mathrm{TM}}\end{array}$ & $70 \mu \mathrm{m}$ & Greiner Bio-One & 542070 \\
\hline $\begin{array}{l}\text { Chemilumines- } \\
\text { cence film, Am- } \\
\text { ersham Hyper- } \\
\text { film }{ }^{\mathrm{TM}} \mathrm{ECL}\end{array}$ & $18 \times 24 \mathrm{~cm}$ & GE Healthcare & 28906837 \\
\hline Cover slips & $20 \times 20 \mathrm{~mm}$ & Carl Roth & $\mathrm{H} 873.2$ \\
\hline CryoPure Tubes & $1.8 \mathrm{ml}$ & Sarstedt & 72.379 \\
\hline Disposable filter & $0.2 \mu \mathrm{m}$ & Th. Geyer & 90491011 \\
\hline $\begin{array}{l}\text { Disposable } \\
\text { scalpel }\end{array}$ & No. 21 & PFM Medical & 02.011 .30 .021 \\
\hline $\begin{array}{l}\text { Glass Pasteur } \\
\text { Pipette }\end{array}$ & $225 \mathrm{~mm}$ & BRAND & ISO 7712 \\
\hline \multirow[t]{2}{*}{ Microplates } & 96-well, clear & Sarstedt & 82.1581 \\
\hline & 96-well, white & Greiner Bio-One & 655075 \\
\hline $\begin{array}{l}\text { Microscope } \\
\text { Slides }\end{array}$ & $76 \times 26 \mathrm{~mm}$ & Th. Geyer & 7695002 \\
\hline $\begin{array}{l}\text { Nitrocellulose } \\
\text { Blotting Mem- }\end{array}$ & $\begin{array}{l}300 \mathrm{~mm} \times 4 \mathrm{~m}, 0.45 \\
\mu \mathrm{m}\end{array}$ & GE Healthcare & 10600003 \\
\hline
\end{tabular}




\begin{tabular}{|c|c|c|c|}
\hline $\begin{array}{l}\text { brane, } \\
\text { Amersham }^{\mathrm{TM}} \\
\text { Protran }^{\mathrm{TM}}\end{array}$ & & & \\
\hline PCR strips & $8 \times 0.2 \mathrm{ml}$ & Greiner Bio-One & 673210 \\
\hline PCR strip caps & n.a. & Greiner Bio-One & 373250 \\
\hline Petri dish & $92 \times 16 \mathrm{~mm}$ & Sarstedt & 82.1473 .001 \\
\hline \multirow{3}{*}{ Pipette tips } & $10 \mu \mathrm{l}$ & \multirow{3}{*}{ Sarstedt } & 70.1130 \\
\hline & $200 \mu \mathrm{l}$ & & 70.760 .012 \\
\hline & $1000 \mu \mathrm{l}$ & & 70.762 .010 \\
\hline \multirow[t]{3}{*}{ Reaction cups } & $0.5 \mathrm{ml}$ & \multirow[t]{3}{*}{ Sarstedt } & 72.699 \\
\hline & $1.5 \mathrm{ml}$ & & 72.690 .001 \\
\hline & $2.5 \mathrm{ml}$ & & 72.691 \\
\hline $\begin{array}{ll}\text { Syringe, } & \text { Luer- } \\
\text { Lok }^{T M} & \text { Plasti- } \\
\text { pak }^{T M} & \end{array}$ & $60 \mathrm{ml}$ & $\begin{array}{l}\text { BD Medical Technol- } \\
\text { ogy }\end{array}$ & 300865 \\
\hline $\begin{array}{l}\text { Syringe, Microli- } \\
\text { ter }^{T M} \text { Hamilton }\end{array}$ & $710 \mathrm{~N}$ & Carl Roth & $\mathrm{X} 036.1$ \\
\hline \multirow{3}{*}{$\begin{array}{l}\text { Serological pi- } \\
\text { pettes }\end{array}$} & $5 \mathrm{ml}$ & \multirow[t]{3}{*}{ Sarstedt } & 86.1253 .001 \\
\hline & $10 \mathrm{ml}$ & & 86.1254 .001 \\
\hline & $25 \mathrm{ml}$ & & 86.1685 .001 \\
\hline \multirow[t]{2}{*}{ Tubes } & $15 \mathrm{ml}$ & \multirow[t]{2}{*}{ Sarstedt } & 62.554 .502 \\
\hline & $50 \mathrm{ml}$ & & 62.547 .254 \\
\hline
\end{tabular}

\subsection{Devices}

Laboratory devices for experiments are listed in Table 17.

Table 17: Devices

\begin{tabular}{|l|l|l|}
\hline \multicolumn{1}{|c|}{ Application } & \multicolumn{1}{c|}{ Device } & Manufacturer \\
\hline Cell counting & Neubauer chamber & Marienfeld \\
\hline Cell culture incubator & CB159 & Binder \\
\hline Cell freezing & Mr. Frosty ${ }^{\mathrm{TM}}$ & Nalgene \\
\hline Centrifugation & Centrifuge 5415R & Eppendorf \\
\cline { 2 - 3 } & Centrifuge 5810R & Eppendorf \\
\cline { 2 - 3 } & Micro Centrifuge & Carl Roth \\
\hline Electrophoresis chamber & PerfectBlue & Peqlab \\
\hline Fume hood & n.a. & Köttermann \\
\hline
\end{tabular}




\begin{tabular}{|c|c|c|}
\hline Heating block & BT2000 & Kleinfeld Labortechnik \\
\hline Hypoxia workstation & InvivO $\mathrm{O}_{2} 400$ & Baker Ruskinn \\
\hline \multirow[t]{3}{*}{ Imaging } & $\begin{array}{l}\text { IX83, inverted fluorescence } \\
\text { microscope }\end{array}$ & Olympus \\
\hline & $\begin{array}{l}\text { Axiovert } 200 \mathrm{M} \text {, } \\
\text { fluorescence microscope }\end{array}$ & Zeiss \\
\hline & $\begin{array}{l}\text { LSM 510-META, confocal } \\
\text { laser scanning microscope }\end{array}$ & Zeiss \\
\hline Immunoblotting Transfer & $\begin{array}{l}\text { PerfectBlue } \quad \text { Semi-Dry } \\
\text { Electroblotter }\end{array}$ & Peqlab \\
\hline Laminar flow hood & Hera Safe K12 & Thermo Electron \\
\hline Luminometer & Centro LB 960 & Berthold Technologies \\
\hline Magnetic stirrer & Ikamag ${ }^{\circledR} \mathrm{RH}$ & IKA Labortech \\
\hline Microplate reader & Centro LB 960 & Berthold Technologies \\
\hline Mixer & Vortex-Genie 2 & Scientific Industries \\
\hline PCR cycler & Primus 96 Thermocycler & Peqlab \\
\hline Pipette filler & Pipetus $^{\circledR}$ & Hirschmann \\
\hline Real-Time PCR cycler & $\mathrm{Mx3000P}$ & Strategene \\
\hline Scale & AC 2115 & Satorius \\
\hline Shaker & Minitron & INFORNS HAT AG \\
\hline Spectrophotometer & NanoDrop 2000c & Thermo Fisher Scientific \\
\hline Water bath & Störktronic W22 & Medigen \\
\hline
\end{tabular}

\subsection{Software}

Software used for analysing the data is given in Table 18. Figure 2, 5 and 6 were created with BioRender (https://biorender.com/).

Table 18: Software

\begin{tabular}{|l|c|l|}
\hline \multicolumn{1}{|c|}{ Product } & Version & \multicolumn{1}{c|}{ Manufacturer } \\
\hline Adobe Photoshop CS2 & 9.0 & Adobe Systems \\
\hline Citavi & 6.3 & Swiss Academic Software \\
\hline CorelDRAW ${ }^{\circledR}$ X5 & 15.2 .0 .661 & Corel Corporation \\
\hline GraphPad PRISM 5 & 5.01 & GraphPad Software \\
\hline Image J & $1.51 \mathrm{~g}$ & Wayne Rasband \\
\hline Microsoft Office Excel & 2016 & Microsoft \\
\hline Microsoft Office Word & 2016 & Microsoft \\
\hline
\end{tabular}




\begin{tabular}{|l|c|l|}
\hline MxPro Mx3005P & V4.10 & Agilent Technologies \\
\hline NanoDrop 2000 software & 1.5 & Thermo Fisher Scientific \\
\hline
\end{tabular}

\subsection{Cell biological methods}

\subsubsection{Cell Cultivation}

Cell lines (C2C12, MEF and L929) were cultured in DMEM high glucose medium supplemented with $10 \%$ FBS and $1 \%$ P/S (Tab. 3). Primary skin fibroblasts were cultured in DMEM/F12 (1:1) medium supplemented with 10\% FBS, 1\% P/S and 1\% MEM-NEAA (Tab. $3)$. In general, cells were cultured under normoxic conditions $\left(20 \% \mathrm{O}_{2}\right)$ in a humidified incubator with $5 \% \mathrm{CO}_{2}$ at $37^{\circ} \mathrm{C}$. For hypoxic experiments, cells were incubated in a humidified hypoxia working station (Ruskinn) with a reduced oxygen supply of $1 \% \mathrm{O}_{2}, 5 \% \mathrm{CO}_{2}$ and $37^{\circ} \mathrm{C}$. In order to maintain the knockdown of ArhGAP29 and HIF-1a in L929 cells, the medium was constantly enriched with $20 \mu \mathrm{g} / \mathrm{ml}$ puromycin. The L929 non-targeting shRNA control cells (shC) were treated with the same amount of puromycin for constant selection.

\subsubsection{Isolation and cultivation of murine primary skin fibroblasts}

Primary skin fibroblasts (PSF) were isolated from murine tail tissue. Therefore, mice were sacrificed by $\mathrm{CO}_{2}$ inhalation followed by cervical dislocation. Ethanol sterilised tails were removed with a sterile scalpel and washed in $70 \% \mathrm{EtOH}$ for $10 \mathrm{~min}$. The removal of tails was followed by an incubation of the tails in primary fibroblast culture medium (Tab. 3 ) on ice for $1 \mathrm{~h}$. Next, tails were briefly washed in $1 \mathrm{x}$ PBS supplemented with $2 \% \mathrm{P} / \mathrm{S}$ and with $70 \%$ $\mathrm{EtOH}$ for $10 \mathrm{~min}$. After the washing steps, tails were minced using a sterile scalpel and digested by $400 \mathrm{U} / \mathrm{ml}$ Collagenase Type II (Tab. 6) at $37^{\circ} \mathrm{C}$ overnight under constant stirring. The digested tissue was filtered through a $70 \mu \mathrm{m}$ nylon cell strainer and centrifuged for $5 \mathrm{~min}$ at $200 \mathrm{x}$ g. The cell pellet was gently resuspended in primary fibroblast culture medium (Tab. 3). Next, the cell suspension was plated on a $75 \mathrm{~cm}^{2}$ cell culture flask. To remove nonfibroblasts and cell debris, the medium was removed after $24 \mathrm{~h}$ and adherent cells were washed three times with 1x PBS. Fresh fibroblast media was added, and cells were cultured under normal cell culture conditions (2.17.1).

\subsubsection{Cell contraction assay}

Three-dimensional collagen matrices were used to measure contractile forces of primary skin fibroblasts. The collagen-based cell contraction assay was performed following the manufacturer's guidelines (Cell Biolabs). In short, cells were detached from the cell culture plates 
using Trypsin/EDTA solution (Tab. 3) and resuspended in primary fibroblast medium. Collagen lattice was prepared by mixing $100 \mu \mathrm{l}$ of cell suspension containing a final concentration of $5 \times 10^{6} \mathrm{cells} / \mathrm{ml}$ and $400 \mu \mathrm{l}$ of collagen gel working solution. Next, $0.5 \mathrm{ml}$ of the cellcollagen mix was added in a well of a 24 -well plate and incubated for $1 \mathrm{~h}$ at $37^{\circ} \mathrm{C}$. Fibroblast culture medium was added after polymerisation of the collagen gel. The cell-collagen gels were incubated under normal cell culture conditions for one day, followed by an additional 24 $\mathrm{h}$ of normoxic $\left(20 \% \mathrm{O}_{2}\right)$ or hypoxic $\left(1 \% \mathrm{O}_{2}\right)$ incubation respectively. Contracting cells cause mechanical tension in the polymerised collagen matrix. Releasing the attached collagen matrix from the sides of the culture dish with a sterile spatula results in mechanical unloading and contraction of the gel. As a control, cells were treated with 2,3-Butanedione Monoxime (BDM), a contraction inhibitor, 30 min before releasing the gel. To document the collagen gel size change, pictures were taken using an $8 \mathrm{MP}$ cell phone camera. The collagen gel size change, determined as collagen area to well area ratio, was quantified using ImageJ software.

\subsubsection{Lipid-based transfection}

Lipid-based transfection of cells was performed by using Lipofectamine ${ }^{\mathrm{TM}} 2000$ according to the manufacturer's instructions (Invitrogen/Thermo Fisher Scientific). For the transfection procedure, $2 \times 10^{4}$ cells $/ \mathrm{ml}$ were plated in a well of a 24 -well plate. Thirty minutes prior transfection, medium was replaced with antibiotic-free medium. The plasmid of interest was added to $50 \mu \mathrm{l}$ Opti-MEM. Furthermore, $2 \mu \mathrm{l}$ of Liptofectamine ${ }^{\mathrm{TM}} 2000$ was diluted in $50 \mu \mathrm{l}$ of OptiMEM and incubated for 5 min at RT. Liptofectamine ${ }^{\mathrm{TM}} 2000$ mix and plasmid mix were combined and incubated for $20 \mathrm{~min}$ at RT. Cells were transfected with $100 \mu \mathrm{l}$ of the complexes per well. After $24 \mathrm{~h}$ incubation, media was replaced with fresh media containing $1 \% \mathrm{P} / \mathrm{S}$. Transfected cells were cultured according to further experimental setups.

\subsubsection{Production of lentiviral particles}

Knockdown of ArhGAP29 in primary skin fibroblasts was generated by lentiviral delivery of shRNA. Non-targeting shRNA was used as a control. Lentiviral particles were produced in human embryonic kidney cells (HEK293T). For this purpose, a total number of $7 \times 10^{6}$ HEK293T cells was seeded on a $75 \mathrm{~cm}^{2}$ cell culture flask and cultured in antibiotic-free DMEM supplemented with 10\% FBS until cells were confluent. The medium was exchanged with Opti-MEM ${ }^{\circledR}$ supplemented with $10 \%$ FBS. A transfection mix containing packaging plasmids and either a plasmid targeting the ArhGAP29 gene or a non-targeting RNA control (shRNA, Tab. 15) was prepared in serum-free Opti-MEM ${ }^{\circledR}$ as shown in Table 19. Following 
an incubation of 5 min at RT, Lipofectamine ${ }^{\mathrm{TM}} 2000$ mix (36 $\mu$ l Lipofectamine ${ }^{\mathrm{TM}} 2000$ in serum-free Opti-MEM ${ }^{\circledR}$, total volume $1.5 \mathrm{ml}$ ) was added to the transfection mix and blended gently. After an incubation of $20 \mathrm{~min}$ at RT, the transfection mix was carefully added to the HEK293T cells. The medium was replaced with antibiotic-free DMEM supplemented with $10 \%$ FBS after $24 \mathrm{~h}$.

Lentiviral particle-containing supernatant was harvested $48 \mathrm{~h}$ after transfection. Optional, fresh antibiotic-free DMEM supplemented with 10\% FBS was added to the cells for an additional harvest of lentiviral particle-containing supernatant after 24 h. In any case, lentiviral particles were purified and concentrated using Lenti- $X^{\mathrm{TM}}$ concentrator according to the manufacturer's protocol (Clontech) immediately. In brief, the supernatant was centrifuged at 2,000 $\mathrm{xg}$ for $15 \mathrm{~min}$ at $4^{\circ} \mathrm{C}$ to remove cell debris. Next, the supernatant was transferred into a new tube and Lenti- $\mathrm{X}^{\mathrm{TM}}$ concentrator was added in a proportion rate of $1: 3$ to the total volume of supernatant. After incubation at $4^{\circ} \mathrm{C}$ for $45 \mathrm{~min}$, the lentiviral particle-containing supernatant was centrifuged at $500 \times g$ at $4^{\circ} \mathrm{C}$ for $45 \mathrm{~min}$. The resulting viral particle-containing pellet was resuspended in $2 \mathrm{ml}$ DMEM medium supplemented with 10\% FBS and 1\% P/S. Virus containing suspension was stored at $-80^{\circ} \mathrm{C}$ until transduction experiments.

Table 19: Lentiviral transfection mix

\begin{tabular}{|c|c|}
\hline Plasmid & Amount [ $\mu \mathrm{g}]$ \\
\hline pLP1 & 4.2 \\
\hline pLP2 & 2 \\
\hline pLP-VSVG & 2.8 \\
\hline $\begin{array}{l}\text { pLKO.1-puro targeting ArhGAP29 } \\
\text { or non-targeting control }\end{array}$ & 3 \\
\hline
\end{tabular}

\subsubsection{Lentiviral transduction}

Lentiviral delivery of shRNA targeting ArhGAP29 was performed in primary skin fibroblasts in order to induce a genetic knockdown of ArhGAP29.

After successful isolation of primary skin fibroblasts (2.17.2), cells were detached from the cell culture plate surface using enzymatic active Trypsin/EDTA solution for 5 min at $37^{\circ} \mathrm{C}$. The process was stopped by adding primary fibroblast culture medium. The cell suspension was collected and gently spun down at $200 \times \mathrm{g}$ and $4^{\circ} \mathrm{C}$. The cell pellet was suspended in primary fibroblast medium and equally distributed on a 6-well plate. As soon as the cells reached $50 \%$ confluency, lentiviral transduction was initiated. For this purpose, lentiviral particle-containing supernatant (2.17.5) was thawed. Next, $1 \mathrm{ml}$ of lentiviral supernatant of the respective condition (ArhGAP29 targeting or non-targeting shRNA control) and $1 \mathrm{ml}$ of pri- 
mary fibroblast medium was added to each well and mixed gently. To improve the lentiviral transduction rate, $8 \mu \mathrm{g} / \mathrm{ml}$ hexadimethrine bromide (polybrene) were added. Cells were incubated for $48 \mathrm{~h}$ under normal cell culture conditions (2.17.1).

Cells were washed with primary fibroblast medium and selected with $7 \mu \mathrm{g} / \mathrm{ml}$ puromycin for 24 h. Non-transduced, dead cells were removed by several washing steps with primary fibroblast medium. Fresh medium was added to successfully selected transduced cells. Cells were maintained and expanded according to the required experimental setup. ArhGAP29 knockdown was verified by qRT-PCR analysis (2.20.3). In each experiment, besides a nontargeting shRNA control, a non-transduced control was maintained as well. Each condition was performed in duplicates.

\subsubsection{Luciferase reporter gene assay}

For reporter gene analysis 90-95\% confluent L929 cells were transfected with 1 ug of pSRE$\mathrm{L}$ and $\mathrm{pRL}$-TK plasmid per well of a 24-well plate using Lipofectamin ${ }^{\mathrm{TM}} 2000$ according to the manufacturer's guidelines. Transfections and untreated controls were performed in triplicates. Cells were either introduced to hypoxic conditions $24 \mathrm{~h}$ after transfection or were kept under normoxic conditions as a control. For reporter gene analysis, cells were lysed $48 \mathrm{~h}$ after transfection in normoxic, and after $24 \mathrm{~h}$ in hypoxic culture conditions respectively.

Activity of Firefly luciferase and Renilla luciferase was measured by using the DualLuciferase Reporter Assay System (Promega) according to the manufacturer's protocol. In short, medium was removed and cells were washed with 1x PBS followed by cell lysis with $50 \mu \mathrm{l}$ of the provided $1 \mathrm{x}$ passive lysis buffer (PLB). Cell lysates were gently rocked for $15 \mathrm{~min}$ at RT and stored at $-20^{\circ} \mathrm{C}$ for $24 \mathrm{~h}$ before the Luciferase activity was determined. For luciferase activity measurements, cell lysates were thawed on ice, $10 \mu$ of the lysate were transferred to luminometer suitable 96-well multiplate containing $10 \mu \mathrm{l}$ of lyophilised Luciferase Assay Reagent II (LAR II). Firefly activity was detected by a microplate luminometer. Renilla firefly activity was initiated by adding $10 \mu \mathrm{l}$ of STOP \& GLO ${ }^{\circledR}$ reagent and quantified by a microplate luminometer. Detected Firefly luciferase activity was then normalised to Renilla intensity. Minor variations of the given protocol included freezing of the cell lysates and a reduced amount of cell lysate and of certain reagents are mentioned for PLB, LAR II, STOP\&GLO. 


\subsection{Histological methods}

\subsubsection{Immunocytochemistry}

In order to visualise the location of specific proteins in cells, immunofluorescence staining was performed. In brief, cells were cultured on coverslips, washed with PBS and fixed with $4 \%$ PFA for $15 \mathrm{~min}$ at RT. For permeabilisation, cells were washed and incubated in $0.2 \%$ Triton X-100/PBS for $15 \mathrm{~min}$. Next, blocking buffer (1\% BSA/PBS) was added for $5 \mathrm{~min}$ at RT. After blocking, primary antibody diluted in PBS was added (Tab. 9). Samples were kept in a wet chamber at RT for $2 \mathrm{~h}$ to allow the primary antibody to bind to its antigen. Following three washing steps with PBS, a fluorophore-coupled secondary antibody (Tab. 11) diluted in PBS or a conjugated fluorescent phalloidin probe (was added and incubated for $1 \mathrm{~h}$ in a wet chamber in the dark at RT. After washing three times with PBS, nuclei were stained with DAPI for 5 min at RT in the dark. After three additional washing steps with PBS, cells were mounted with Fluoromount ${ }^{\mathrm{TM}}$. Analyses were performed using different microscope setups (Tab. 17). Images were processed further with ImageJ and Adobe Photoshop CS2.

\subsubsection{Quantification of actin clusters}

To quantify F-actin clusters in cells, MiToBo Actin Analyzer 2D plugin (http://mitobo.informatik.uni-halle.de/index.php/Applications/ActinAnalyzer2D) (Möller et al., 2016) was used in ImageJ.

\subsection{Protein biochemical methods}

\subsubsection{Protein extraction}

For protein extraction, cells were washed twice with PBS, and excess liquid was discarded. Cells were lysed in ice cold lysis buffer and scraped off the cell culture dish. Homogenised cell lysates were transferred to pre-chilled reaction cups and shortly incubated on ice. Hypoxic samples were collected within the hypoxia workstation. Following a gentle mix of the cell lysates, samples were centrifuged at $13,000 \times \mathrm{g}$ for $10 \mathrm{~min}$ at $4^{\circ} \mathrm{C}$. The protein containing supernatant was collected and transferred to a pre-chilled reaction cup. Protein concentration was determined by Bradford assay. Cell lysates were stored at $-80^{\circ} \mathrm{C}$ unless directly processed for SDS-PAGE (4.19.3). 


\subsubsection{Bradford assay}

Bradford assay was used to determine the protein concentration of cell lysates. Therefore, $1 \mu \mathrm{l}$ of the cell lysate was mixed with $200 \mu \mathrm{l}$ 1:5 Protein Assay Dye Reagent Concentrate in a 96-well plate. To calculate total protein concentration, the absorbance at $595 \mathrm{~nm}$ was measured with a microplate reader and compared to a BSA standard curve (range from $0.5 \mu \mathrm{g} / \mu \mathrm{l}$ to $4 \mu \mathrm{g} / \mu \mathrm{l})$.

\subsubsection{SDS-PAGE}

Protein samples were separated according to their molecular weight by using the electric field of the sodium dodecyl sulphate polyacrylamide gel electrophoresis (SDS-PAGE). The system consists of two gels, the stacking gel (5\%) and the resolving gel (6\% or $10 \%)$ as represented in Table 20. If not shown differently, $10 \%$ resolving gels were used to detect HIF-1 $\alpha$ protein, whereas $6 \%$ resolving gels were used to separate and detected ArhGAP29. For RhoA activity assays, $12 \%$ resolving gels were used.

Cell lysates were mixed with $6 x$ Laemmli loading buffer containing SDS and $\beta$ mercaptoethanol, which leads to protein denaturation by breaking up non-covalent bonds. Samples were loaded into the polyacrylamide gel and ran at $40 \mathrm{~mA}$ to $50 \mathrm{~mA}$. The PageRuler $^{\mathrm{TM}}$ Prestained Protein Ladder was used for protein size determination.

Table 20: Composition of stacking and resolving gel

\begin{tabular}{|l|c|c|c|c|}
\hline \multirow{2}{*}{ Component } & $\begin{array}{c}\text { Stacking gel } \\
\text { [ml] }\end{array}$ & \multicolumn{3}{|c|}{$\begin{array}{c}\text { Resolving gel } \\
\text { [ml] }\end{array}$} \\
\cline { 2 - 5 } & $5 \%$ & $6 \%$ & $10 \%$ & $12 \%$ \\
\hline $\mathrm{ddH}_{2} \mathrm{O}$ & 6.8 & 15.9 & 11.9 & 9.9 \\
\hline $30 \%$ acrylamide mix & 1.7 & 6 & 10 & 12 \\
\hline $1,5 \mathrm{M}$ TRIS/HCl $(\mathrm{pH} 8,8)$ & - & 7.5 & 7.5 & 7.5 \\
\hline $1,0 \mathrm{M}$ TRIS/HCl $(\mathrm{pH} 6,8)$ & 1.25 & - & - & - \\
\hline $10 \%$ SDS & 0.1 & 0.3 & 0.3 & 0.3 \\
\hline $10 \%$ ammonium persulfate & 0.1 & 0.3 & 0.3 & 0.3 \\
\hline TEMED & 0.01 & 0.024 & 0.012 & 0.012 \\
\hline
\end{tabular}




\subsubsection{Immunoblot (Western Blot)}

Following the protein separation by SDS-PAGE (2.19.3), proteins were transferred onto a nitrocellulose membrane by using a semi-dry immunoblotting technique to visualise and analyse them. In short, the gel, nitrocellulose membrane and filter paper were soaked in immunoblot transfer buffer (25 mM TRIS,192 mM glycine, 20\% methanol), before stacking them in the following order: a layer of three filter papers, nitrocellulose membrane, gel and another layer of 3 filter papers. The transfer was performed using the peqlab PerfectBlue ${ }^{\mathrm{TM}}$ Semi-Dry Electroblotter running at $2 \mathrm{~mA} / \mathrm{cm}^{2}(280 \mathrm{~mA}, 30 \mathrm{~V})$ for $1 \mathrm{~h}$. The semi-dry immunoblotting technique uses an electric field, allowing negatively charged proteins to be transferred to the nitrocellulose membrane due to the attraction of a positive anode.

To visualise successfully transferred proteins, the nitrocellulose membrane was stained with Ponceau S staining solution. Afterwards, the nitrocellulose membrane was washed with PBS to remove the Ponceau $S$ staining and incubated in 5\% skim milk powder dissolved in PBS for $1 \mathrm{~h}$ at RT to prevent unspecific antibody binding by blocking the membrane. Primary antibody was diluted in 5\% skim milk powder / PBS according to table 8 and added to the nitrocellulose membrane overnight at $4^{\circ} \mathrm{C}$. After incubation with primary antibody, the membrane was washed three times with PBS or TBS-T for $10 \mathrm{~min}$ at RT. HRP-coupled secondary antibody diluted in $5 \%$ skim milk powder/PBS was added for $1 \mathrm{~h}$ at RT. Finally, the membrane was washed three times for 10 min in PBS at RT. The membrane was incubated in ECL solution for $1 \mathrm{~min}$. For visualisation of the proteins, the membrane was exposed to chemiluminescence sensitive films.

\subsubsection{Rho GTPase activity assay}

To detect active RhoA, a specific pulldown assay using the protein interaction with the Rho GTPase binding domain (RBD) from Rhotekin was performed.

\subsubsection{Production of GST-RBD proteins}

Glutathione-S-transferase-Rho binding domain of Rhotekin (GST-RBD) protein plasmids taken from glycerol stocks (BL21 pGEX-GST-RBD-Rhotekin) were inoculated in $100 \mathrm{ml} 100$ $\mu \mathrm{g} / \mathrm{ml}$ AMP-containing LB medium at $37^{\circ} \mathrm{C}$ overnight under shaking conditions. The culture was diluted 1:20 in fresh $500 \mathrm{ml}$ LB medium supplemented with $100 \mu \mathrm{g} / \mathrm{ml}$ AMP and incubated for 2 to $3 \mathrm{~h}$ at $37^{\circ} \mathrm{C}$ under shaking conditions. To induce the expression of the GST-RBD protein, $0.5 \mathrm{mM} \mathrm{IPTG}$ was added at $30^{\circ} \mathrm{C}$ for $2 \mathrm{~h}$. The supernatant was spun down at $2,000 \mathrm{x}$ $\mathrm{g}$ for $15 \mathrm{~min}$. Pelleted bacteria was stored at $-80^{\circ} \mathrm{C}$ until further usage. 


\subsubsection{Production of GST-RBD protein beads}

Pelleted bacteria were lysed in $4 \mathrm{ml}$ ice-cold lysis buffer (STE-PMSF) to recover GST-RBD protein. The pellet was homogenised using a $19 \mathrm{G}$ needle. To digest bacterial membranes, $100 \mu \mathrm{g} / \mathrm{ml}$ lysozyme dissolved in $500 \mu \mathrm{l}$ ice-cold lysis buffer (STE-PMSF) was added and incubated on ice for $15 \mathrm{~min}$. Next, $5 \mathrm{mM}$ DTT was added and gently mixed, followed by $1 \%$ Tween $^{\circledR}-20$ and $0.03 \%$ SDS. The total volume of the solution was equally distributed to 5 reaction cups before centrifuged at $14,000 \times \mathrm{g}$ at $4^{\circ} \mathrm{C}$ for $30 \mathrm{~min}$. The GST-RBD proteincontaining supernatant was collected.

Before the Glutathione Sepharose ${ }^{T M}$ beads were added to the supernatant, they had to be washed carefully. Therefore, $30 \mu$ l Glutathione Sepharose ${ }^{\mathrm{TM}}$ beads per condition were washed twice with STE-PMSF buffer and spun down gently for $1 \mathrm{~min}$ at $500 \mathrm{x}$ g. Glutathione Sepharose $^{\mathrm{TM}}$ beads were resuspended in $200 \mu \mathrm{l}$ STE-PMSF buffer and added to GST-RBD protein supernatant, which was then incubated for $2 \mathrm{~h}$ at $4^{\circ} \mathrm{C}$ under end-to-end rotation. GST-RBD protein beads were washed with $500 \mu \mathrm{l} 1 \mathrm{x} \mathrm{Mg}^{2+}$ buffer and were centrifuged at 500 $\mathrm{x} \mathrm{g}$ for $1 \mathrm{~min}$. The supernatant was discarded and beads were resuspended and stored in $250 \mu \mathrm{l} 1 \times \mathrm{Mg}^{2+}$ buffer.

\subsubsection{Rho GTPase pulldown}

Cells were washed twice with ice-cold PBS, and lysed in $1 \mathrm{x} \mathrm{Mg}^{2+}$ buffer. Cells were scraped from the cell culture plate, and the lysates were transferred into pre-chilled reaction tubes. Cell lysates were centrifuged at $14,000 \times \mathrm{g}$ at $4^{\circ} \mathrm{C}$ for $5 \mathrm{~min}$. Supernatants were collected and transferred to new cold reaction tubes.

To analyse the total RhoA amount, $40 \mu$ l of the cell lysate supernatant was kept separately. Lysates were incubated with $40 \mu$ of GST-RBD protein beads per condition and incubated for $1.5 \mathrm{~h}$ to $2 \mathrm{~h}$ at $4^{\circ} \mathrm{C}$ under constant rotation. To pulldown the GST-RBD protein beads, lysates were centrifuged gently at $500 \times \mathrm{g}$ for $1 \mathrm{~min}$. Active Rho-GST was bound to the beads. The beads were washed three times with $1 \times \mathrm{Mg}^{2+}$ buffer and centrifuged at $500 \times \mathrm{g}$ at $4^{\circ} \mathrm{C}$ for $2 \mathrm{~min}$. Sample buffer (35 $\mu \mathrm{l}$ x Laemmli) was mixed with 1M DTT (1:5) and added to the samples. Samples were boiled at $95{ }^{\circ} \mathrm{C}$ for 5 min afterwards. Immunoblotting was performed to analyse the active GST-RBD protein and compare it to the whole cell lysates, which were stored previously. 


\subsection{Molecular biological methods}

\subsubsection{RNA isolation}

RNA was isolated according to manufacturer's guidelines using the TRIzol ${ }^{\circledR}$ reagent. In short, cells were washed twice with PBS and lysed in $0.5 \mathrm{ml} \mathrm{TRIzol}{ }^{\circledR}$ reagent. Homogenised cell lysates were transferred into reaction tubes and mixed with $100 \mu \mathrm{l}$ chloroform by gently inverting the tubes for several seconds. After 2 min incubation at RT, lysates were centrifuged at $12,000 \times \mathrm{g}$ for $15 \mathrm{~min}$ at $4{ }^{\circ} \mathrm{C}$ to separate RNA from proteins. After centrifugation, the aqueous RNA-containing phase was transferred in a new reaction tube and mixed with 250 $\mu \mathrm{l}$ isopropanol. In order to precipitate the RNA, samples were incubated at $-20{ }^{\circ} \mathrm{C}$ for $20 \mathrm{~min}$ up to $1 \mathrm{~h}$. After the incubation, samples were mixed again and spun down at $12,000 \times \mathrm{g}$ for $20 \mathrm{~min}$ at $4{ }^{\circ} \mathrm{C}$. The supernatant was removed and the RNA pellet was washed in $0.5 \mathrm{ml} 75 \%$ EtOH followed by a centrifugation step at $12,000 \times \mathrm{g}$ for $10 \mathrm{~min}$ at $4^{\circ} \mathrm{C}$. After washing, the RNA pellet was air dried at RT and resuspended in $11 \mu \mathrm{l}$ nuclease-free water. Samples were incubated at $56{ }^{\circ} \mathrm{C}$ for $10 \mathrm{~min}$ to dissolve the RNA pellet. A spectrophotometer (NanoDrop 200c) was used to determine the RNA concentration. Isolated RNA was stored at $-80^{\circ} \mathrm{C}$ if not used immediately.

\subsection{2 cDNA synthesis}

Isolated RNA was transcribed into complementary DNA (cDNA) using the Fermentas First Strand cDNA Synthesis kit according to manufacturer's guidelines. Briefly, $1 \mu \mathrm{g}$ to $1.5 \mu \mathrm{g}$ of isolated RNA was transcribed into cDNA. Template RNA was incubated with oligo dT primers at $65^{\circ} \mathrm{C}$ for $10 \mathrm{~min}$. For cDNA synthesis, the reaction mix (Tab. 21) was added and the samples were incubated at $37^{\circ} \mathrm{C}$ for $60 \mathrm{~min}$. To stop enzymatic activity, samples were incubated at $70{ }^{\circ} \mathrm{C}$ for $10 \mathrm{~min}$. The cDNA was stored at $-20^{\circ} \mathrm{C}$ upon further usage.

Table 21: cDNA synthesis reaction mix (1x)

\begin{tabular}{|l|c|}
\hline \multicolumn{1}{|c|}{ Reagent } & Volume [ $\boldsymbol{\mu l}]$ \\
\hline M-MLV Reverse Transcriptase & 2 \\
\hline RiboLock RNase Inhibitor & 1 \\
\hline dNTP Mix & 2 \\
\hline 5x Reaction Buffer & 4 \\
\hline Total Volume & 9 \\
\hline
\end{tabular}




\subsubsection{Quantitative real-time PCR (qRT-PCR)}

To quantify and compare gene expression, quantitative real-time polymerase chain reaction (qRT-PCR) was used. cDNA was amplified with specific exon spanning oligonucleotides. SensiMix ${ }^{T M}$ SYBR $^{\circledR}$ Low-ROX kit was used for intercalation of SYBR green fluorescent dye with double-stranded DNA. ROX (5-carboxy-X-rhodamine) is an optional reference fluorescent dye, which was not considered in this experimental setup. Amplification was detected by Agilent Mx3005P light cycler. As transcript abundance correlates with fluorescence intensity, it was possible to quantify gene expression levels by fluorescence measurement. qRT-PCR method was performed according to the manufacturer's instructions (Bioline) using the PCR reaction mix shown in Table 22.

Table 22: qRT-PCR reaction $\operatorname{mix}(1 \mathrm{x})$

\begin{tabular}{|l|c|}
\hline \multicolumn{1}{|c|}{ Reagent } & Volume $[\mu \mathrm{l}]$ \\
\hline SensiMixTM SYBR ${ }^{\circledR}$ Low-ROX kit & 12.5 \\
\hline Primer fw & 0.5 \\
\hline Primer rev & 0.5 \\
\hline cDNA & 1 \\
\hline $\mathrm{H}_{2} \mathrm{O}$ & 10.5 \\
\hline Total volume & 25 \\
\hline
\end{tabular}

qRT-PCR was performed in Agilent Mx3005P light cycler using following cycling programme (Tab. 23) adapted to the gene's specific primer (Tab. 13) annealing temperatures $T_{M}$.

Table 23: qRT-PCR cycling programme

\begin{tabular}{|l|c|c|c|}
\hline \multicolumn{1}{|c|}{ Stage } & Temperature $\left[{ }^{\circ} \mathbf{C}\right]$ & Time $[\mathrm{min}]$ & Cycles \\
\hline Initial activation & 95 & $10: 00$ & 1 \\
\hline Denaturation & 95 & $00: 15$ & \multirow{2}{*}{40} \\
\hline Annealing & $\mathrm{T}_{\mathrm{M}}$ & $00: 20$ & \\
\hline Elongation & 72 & $00: 30$ & \multirow{2}{*}{1} \\
\hline Dissociation & 95 & $1: 00$ & \\
\cline { 2 - 4 } & $\mathrm{T}_{\mathrm{M}}$ & $00: 30$ & \\
\cline { 2 - 4 } & 95 & $00: 30$ & \\
\hline
\end{tabular}


To analyse gene expression levels, the MxPro software and the comparative $\Delta \Delta \mathrm{C}_{\mathrm{T}}$ method was used. The target gene expression was normalised to the unaltered, endogenous reference gene (murine ribosomal protein $\mathrm{S} 12$, ms12; housekeeping gene). The $\mathrm{C}_{\mathrm{T}}$ value represents the amount of PCR cycles after which a sample's fluorescent signal was detectable exceeding the threshold (fluorescent background).

$\Delta \mathrm{C}_{\mathrm{T}}$ values result from the calculated differences between the housekeeping gene $\mathrm{C}_{\mathrm{T}}$-values and the gene of interest $\mathrm{C}_{\mathrm{T}}$-values $\left(\Delta \mathrm{C}_{\mathrm{T}}=\mathrm{C}_{\mathrm{T}}\right.$ gene of interest $-\mathrm{C}_{\mathrm{T}}$ housekeeping gene). The mean value of control samples (i.e. normoxic, wildtype control) was calculated and subtracted from the experimental samples (i.e. hypoxic incubation) $\Delta C_{T}$ values to normalise them, resulting in $\Delta \Delta \mathrm{C}_{\mathrm{T}}$. In order to calculate the relative expression fold change, the $\Delta \Delta \mathrm{C}_{\mathrm{T}}$ values have to be inserted in the formula $2^{-\Delta \Delta C T}$.

\subsection{Statistics}

For statistic analysis and graphic presentation of data sets, GraphPad Prism 5 software was used. To determine statistic outliers, Grubb's test was performed using the freely available online software provided by GraphPad (https://www.graphpad.com/quickcalcs/Grubbs1.cfm). Data were analysed by unpaired 2-tailed Student's t-test. Analysed data are presented with error bars indicating standard error of the mean ( \pm SEM). Statistic significance was set with a $\mathrm{p}$ - value $<0.05$. Analysed sample size is represented in each experiment figure respectively. 


\section{Results}

\subsection{Hypoxia impairs myofibroblast differentiation and contractile function}

\subsubsection{The myofibroblast markers $\alpha$ smooth muscle actin and transgelin are de- creased in hypoxia}

To investigate the effect of reduced oxygenation on the myofibroblast differentiation, murine PSF cultured under standard normoxic conditions $\left(20 \% \mathrm{O}_{2}, 24 \mathrm{~h}\right)$ were exposed to hypoxia $\left(1 \% \mathrm{O}_{2}\right)$ for $4 \mathrm{~h}$ and $24 \mathrm{~h}$. Myofibroblasts differ from fibroblasts in de novo expression of aSMA (Hinz, 2007). Since the most common marker for activated myofibroblasts is aSMA, it was used in this study to distinguish myofibroblasts from fibroblasts.

Under normoxic culture conditions, mRNA expression levels of aSMA increased constantly over time ( 4 to $28 \mathrm{~h}$ after plating). Prolonged normoxic incubation ( $48 \mathrm{~h}$ after plating) resulted in a negligible decrease of aSMA. Notably, after $24 \mathrm{~h}$ in hypoxia, mRNA expression of aSMA decreased significantly in the analysed PSF compared to the normoxic controls (Fig. 7A). Immunofluorescence stainings of PSF furthermore demonstrated that fewer cells expressed the myofibroblast marker aSMA colocalised with actin stress fibers in hypoxia in contrast to normoxia (Fig. 7C). These findings were verified by counting aSMA-positive fibroblasts in which aSMA colocalised with phalloidin stained F-actin (Fig. 7D).

Besides aSMA, transgelin (Tagln) has been reported to be a marker for myofibroblasts (Scharenberg et al., 2014; Dolivo et al., 2017). The Tagln expression profile was found to be similar to the aSMA expression in PSF. In normoxia, Tagln was increased within 4 to $24 \mathrm{~h}$ after plating of the cells. Prolonged normoxia resulted in a slight decrease in Tagln expression. However, the expression of Tagln in hypoxia was significantly reduced after $24 \mathrm{~h}$ compared to the normoxic samples after $48 \mathrm{~h}$ (Fig. 7B).

Taken together, plating PSF on a regular cell culture dish under standard normoxic cell culture conditions resulted in the differentiation of fibroblasts to myofibroblasts. This finding was demonstrated by increased expression of the myofibroblast markers aSMA and Tagln. In contrast, hypoxia impaired the myofibroblast differentiation as shown by reduced expression of aSMA and Tagln. 
A

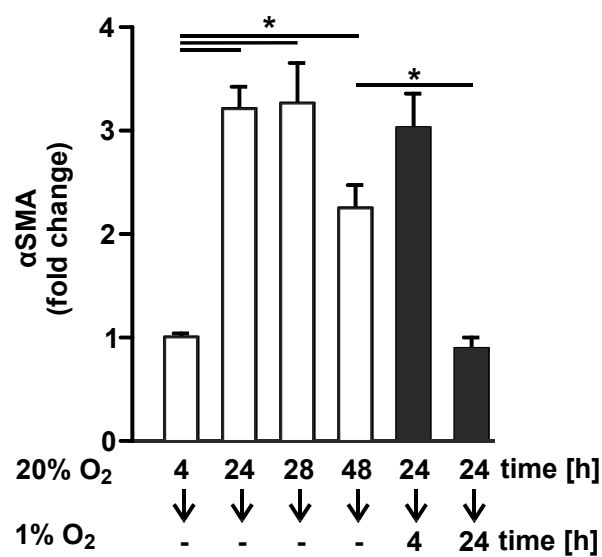

B

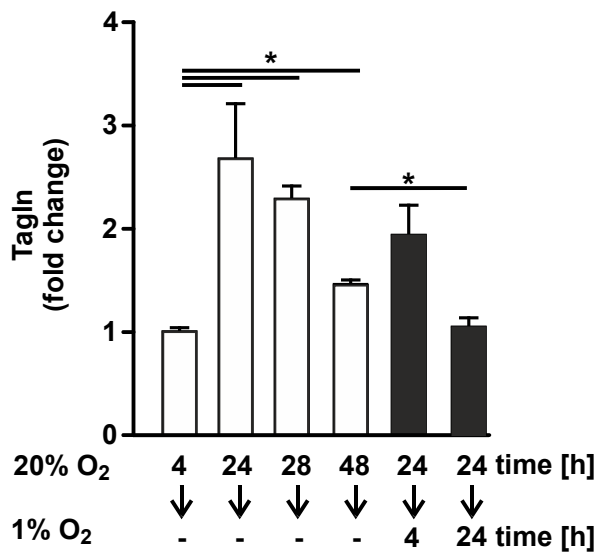

C

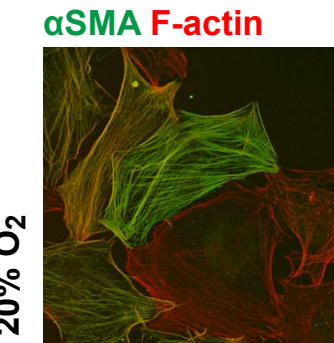

aSMA

F-actin
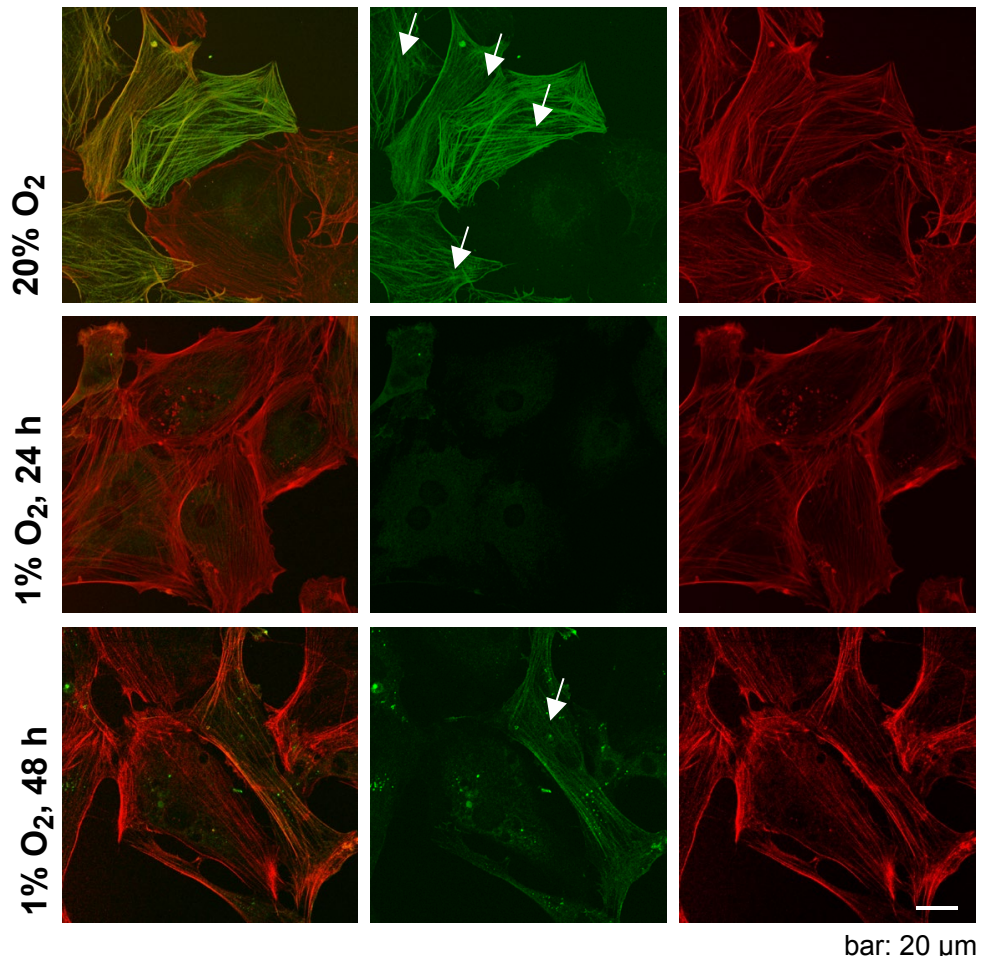

D

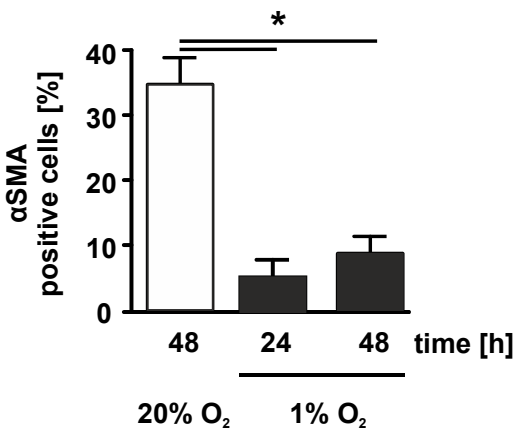

Figure 7: Hypoxia impairs fibroblast to myofibroblast differentiation. Primary skin fibroblasts were cultured in normoxia $\left(20 \% \mathrm{O}_{2}\right)$ or exposed to hypoxia $\left(1 \% \mathrm{O}_{2}\right)$ for the indicated time points. The mRNA expression of the myofibroblast specific markers aSMA (A) and Tagln (B) were analysed by qRT-PCR. In (A) and (B) three to four samples per condition were analysed. The mRNA expression levels were normalised to the housekeeping gene ms12 and are shown as fold change compared to 
normoxia $\left(20 \% \mathrm{O}_{2}, 4 \mathrm{~h}\right)$. Hypoxia resulted in a significant decrease of aSMA and Tagln. (C) Cells were analysed by immunofluorescence and Alexa Fluor ${ }^{\top \mathrm{M}} 594$ conjugated phalloidin staining for aSMA and F-actin. Arrows indicate colocalisation of aSMA with F-actin, identifying aSMA-positive cells. Hypoxia resulted in a reduction of aSMA-positive cells. (D) Cells in which aSMA colocalises with F-actin were counted and quantified as percentage of total cell number. For each condition, at least 200 cells were analysed. Error bars represent mean \pm SEM, $p=\leq 0.05$.

\subsubsection{The stimulating effect of transforming growth factor- $\beta$ on the myofibroblast differentiation is blunted in hypoxia}

The cytokine TGF- $\beta$ plays a significant role in the fibroblast to myofibroblast differentiation process (Midgley et al., 2013). To stimulate the fibroblast to myofibroblast differentiation, PSF were treated with TGF- $\beta$. The cytokine was added to the cells after $24 \mathrm{~h}$ of normoxic incubation and one hour prior to the exposure to hypoxia. Two different concentrations (2 $\mathrm{ng} / \mathrm{ml}$ and $10 \mathrm{ng} / \mathrm{ml}$ ) of TGF- $\beta$ were applied. Treatment with TGF- $\beta$ further stimulated the myofibroblast differentiation in normoxia compared to the untreated control, as shown in a significant increase of $\alpha$ SMA mRNA expression. However, the activating effect of TGF- $\beta$ on the myofibroblast differentiation was blunted in hypoxia (Fig. 8A). Similar results were observed for the expression of Tagln in which a TGF- $\beta$ concentration of $10 \mathrm{ng} / \mathrm{ml}$ resulted in a significant increase of Tagln mRNA expression. This stimulating effect of TGF- $\beta$ was reduced in hypoxia (Fig. 8B).

A

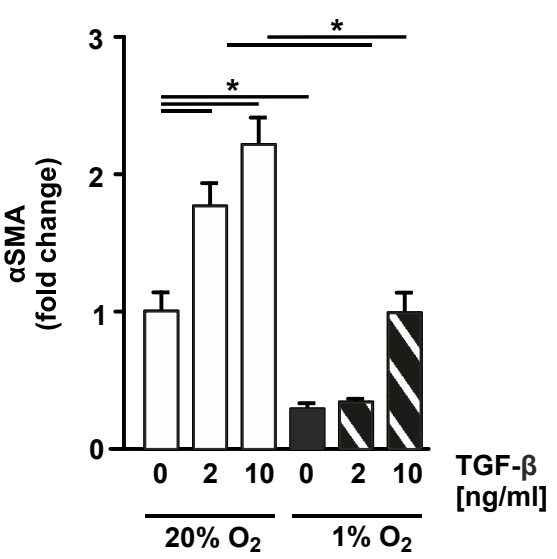

B

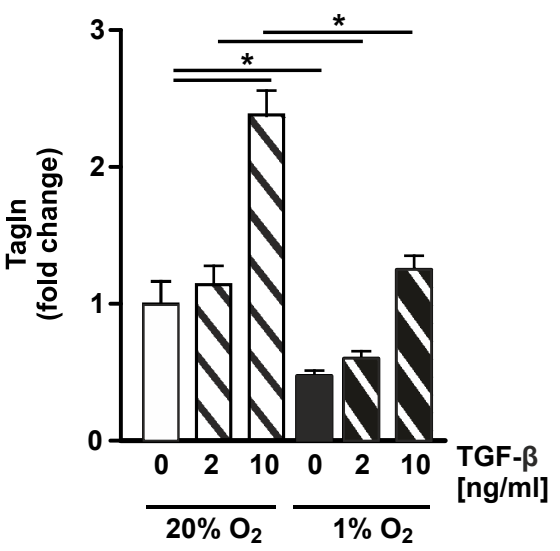

Figure 8: Hypoxia diminishes the stimulating effect of TGF- $\beta$ on the myofibroblast differentiation. Primary skin fibroblasts were treated with the indicated concentrations of TGF- $\beta$ and incubated in normoxia $\left(20 \% \mathrm{O}_{2}\right)$ or hypoxia $\left(1 \% \mathrm{O}_{2}\right)$ for $24 \mathrm{~h}$. The mRNA expression of the myofibroblast specific markers aSMA (A) and Tagln (B) were analysed by qRT-PCR. The mRNA expression levels were normalised to the housekeeping gene $\mathrm{ms} 12$ and are shown as fold change compared to the untreated 
normoxic control. Four samples per condition were analysed. The stimulating effect of TGF- $\beta$ on the fibroblast to myofibroblast differentiation in normoxia was found to be blunted in hypoxia as shown in reduced expression of the myofibroblast markers aSMA and Tagln. Error bars represent mean \pm SEM, $p=\leq 0.05$.

\subsubsection{The ability of primary fibroblasts to develop contractile forces is diminished in hypoxia}

One critical role of myofibroblasts in the wound healing process is the ability to close wounds due to their contractile characteristics (Li and Wang, 2009).

To investigate the ability for contraction, PSF were mixed in three-dimensional collagen matrices and cultured in normoxia. After $24 \mathrm{~h}$ in normoxia, some samples were incubated in hypoxia for $24 \mathrm{~h}$. Mechanical tension in the polymerised collagen matrix is caused by contracting cells. To measure contractile forces, the collagen lattice was released, which resulted in mechanical unloading and shrinkage of the collagen gel. The change of the gel size was analysed by measuring the ratio of collagen area to well area (Fig. 9). In normoxia, the cells developed more contractile forces compared to hypoxia. This resulted in a significantly smaller collagen matrix in the normoxic samples compared to the hypoxic samples. As a control condition, cells were treated with BDM, a myosin ATPase inhibitor, which hinders contraction (Soeno et al., 1999). Upon treatment with the contraction inhibitor BDM, the collagen gel size did not significantly change over time corresponding to less contractile forces.

A

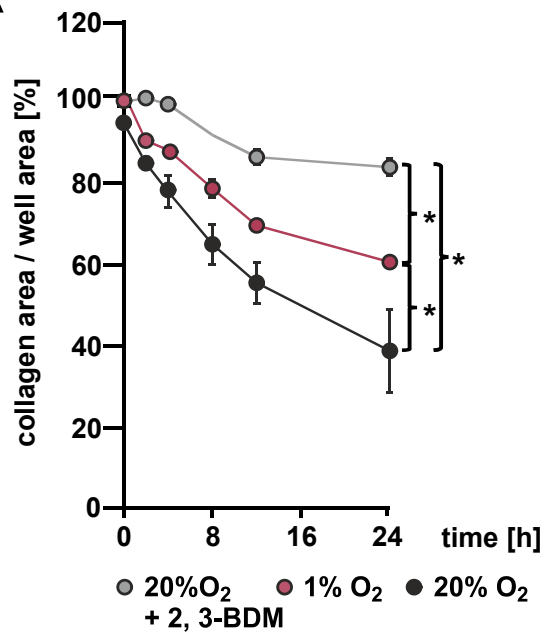

B

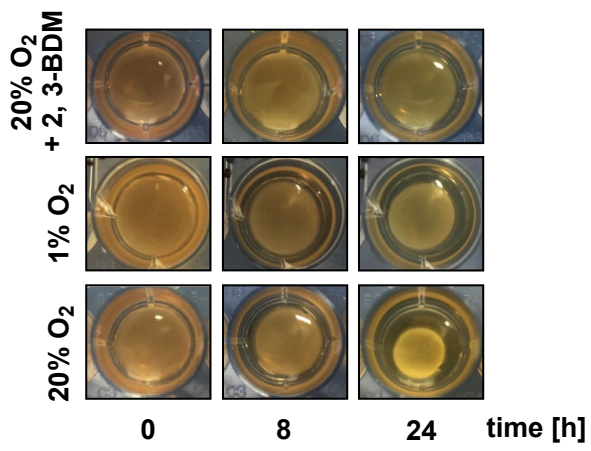

Figure 9: Hypoxia affects the contraction ability of myofibroblasts. (A) Primary skin fibroblasts were plated on collagen matrices and were incubated in normoxia $\left(20 \% \mathrm{O}_{2}\right)$ or hypoxia $\left(1 \% \mathrm{O}_{2}\right)$. Change of the gel size after release was determined by quantifying the collagen area to well area ratio. The graph shows $n=4$ collagen gels per condition. Error bars represent mean $\pm S E M, p=\leq 0.05$. (B) 
Images show the representative collagen gels which were documented 0, 8 and $24 \mathrm{~h}$ after release. Cells isolated from at least four different animals were pooled. In normoxia, the gel size was reduced, indicating a contractile function of the cells. This effect was less distinct in hypoxic samples or under treatment with contraction inhibitor 2, 3-Butanedione Monoxime (BDM).

\subsection{The hypoxia-mediated repression of myofibroblast differentiation is accompa- nied by changes in F-actin structures and RhoA activity}

\subsubsection{F-actin assembly is distinctive in normoxia and hypoxia}

Besides the expression of aSMA, another defining feature of myofibroblasts is the assembly of pronounced, cell traversing stress fibers (Anderson et al., 2004).

F-actin was characterised by phalloidin staining in PSF to evaluate the effect of oxygenation on the stress fiber network. In normoxia, aSMA-positive cells contained long, distinctive actin fibers crossing most of the cell (Fig. 10A, upper panel). By contrast, in non-aSMA-positive PSF cultured in hypoxia, actin filaments appear to be shorter and are predominantly present at the cell periphery (Fig. 10A, lower panel). These findings were quantified by using the nonbiased cluster analysis application MiToBo. Differences in structural patterns in the actin filaments form the basis for texture analysis with this application. Structural patterns with high similarity are defined as clusters. The F-actin quantification confirmed the varying F-actin structures of cells in normoxia and hypoxia by changes of cluster (C1-C6) distribution (Fig. 10B).

A F-actin

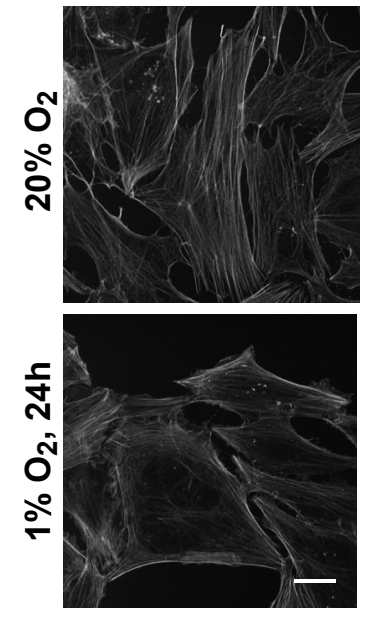

B
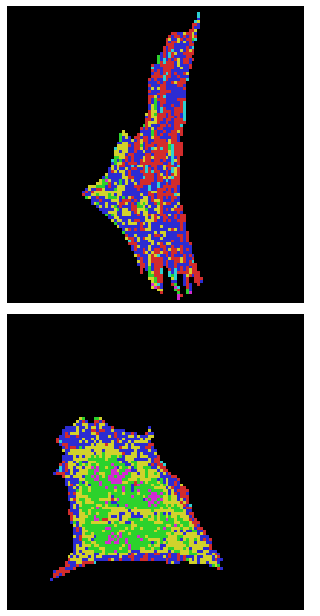

bar: $20 \mu \mathrm{m}$

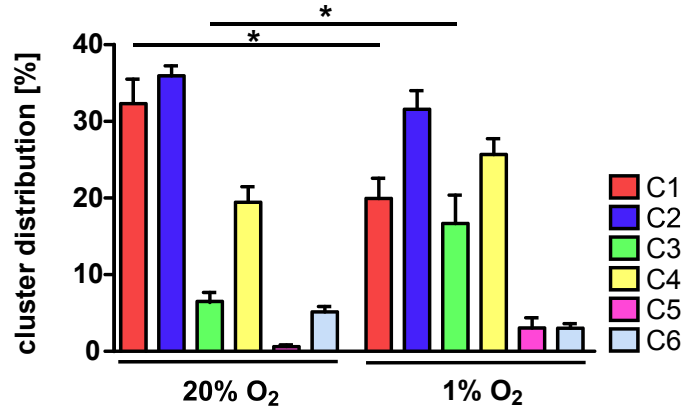

Figure 10: The hypoxia-mediated impairment of myofibroblast differentiation is paralleled by changes of F-actin structures. (A) F-actin of primary skin fibroblasts (PSF) was characterised in normoxia $\left(20 \% \mathrm{O}_{2}\right)$ and hypoxia $\left(1 \% \mathrm{O}_{2}\right)$ by phalloidin staining. PSF analysed in normoxia were aSMA-positive. Cells analysed in hypoxia were non-aSMA-positive. F-actin structures appeared to be 
more pronounced in normoxic aSMA-positive cells, whereas hypoxic, non-aSMA-positive cells showed shorter F-actin structures predominantly in the cell periphery (left panels). The non-biased cluster analysis application MiToBo was applied to generate a pseudo coloured image of the F-actin cluster pattern (right panels). (B) Quantification of F-actin structures based on cluster (C1-C6) distribution analyses with MiToBo. At least $n=11$ cells per condition were analysed. Error bars represent mean \pm SEM, $p=\leq 0.05$.

\subsubsection{Hypoxia induces dynamic changes of RhoA activity}

The Rho GTPase RhoA plays a major role in the stress fiber induction and has been reported to be involved in myofibroblast differentiation ( $\mathrm{Ni}$ et al., 2013).

To investigate if RhoA is involved in myofibroblast differentiation in normoxia, PSF were treated with the Rho inhibitor C3 transferase. Upon C3 transferase treatment, a reduction of aSMA- positive fibroblasts was observed compared to untreated fibroblasts in normoxia (Fig. $11 \mathrm{~A}$ and $\mathrm{B}$ ). Due to its toxic feature, C3 treatment can lead to cell death. Hence, further analysis of aSMA expression, especially in hypoxia, was not possible. The decrease of aSMA-positive myofibroblasts upon C3 transferase treatment was similar to the effect of low oxygen concentration on myofibroblast differentiation shown in chapter 3.1.1. Therefore, further experiments were performed to analyse the role of RhoA activity on oxygen-dependent myofibroblast differentiation.

The effect of hypoxia on RhoA activity in PSF was investigated by performing Rho-GST pulldown assays after $1,4,8,12$ and $24 \mathrm{~h}$ of hypoxic incubation, after having been plated and settled in normoxic conditions at least for $24 \mathrm{~h}$ (Fig. 11C). Upon hypoxic exposure, RhoA activity transiently increased, peaking at 4 to $12 \mathrm{~h}$ of hypoxia. Prolonged hypoxic exposure $(24 \mathrm{~h})$ resulted in a decrease of RhoA activity, similar to the basal level of RhoA activity in normoxia. 
A
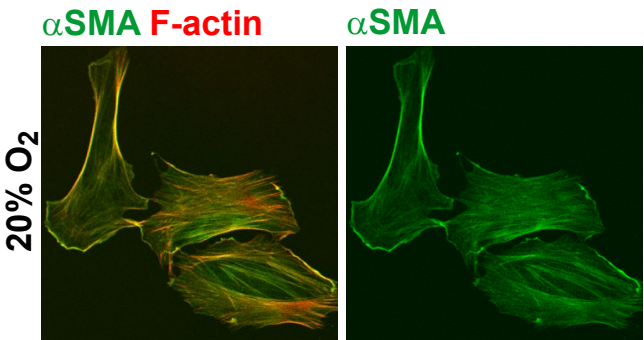

F-actin
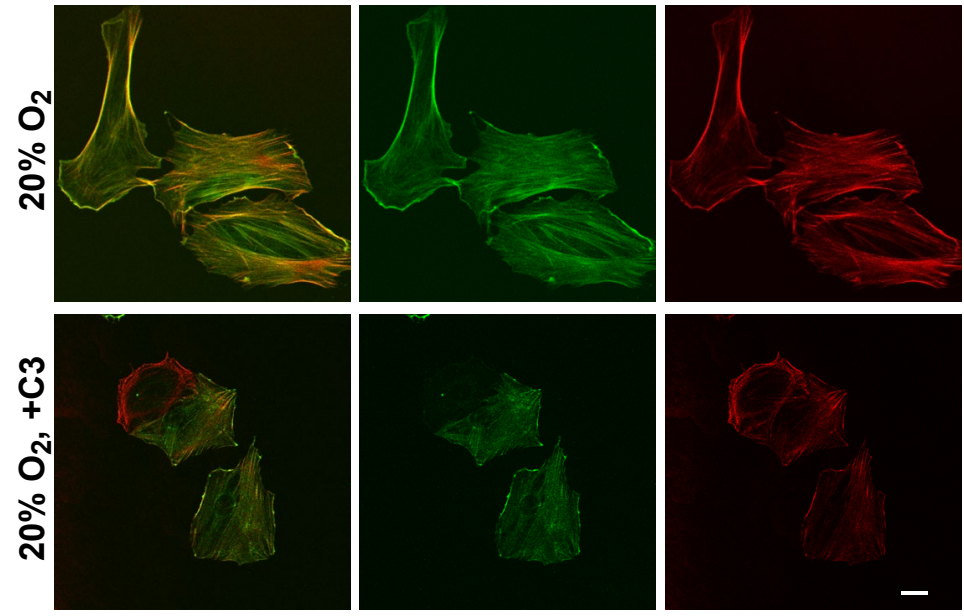

bar: $20 \mu \mathrm{m}$

B

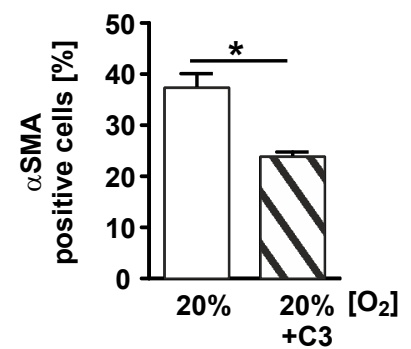

C

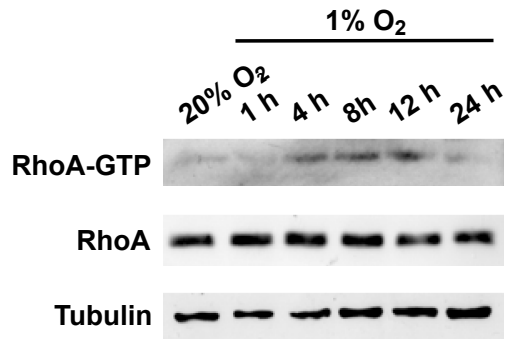

Figure 11: The hypoxia-mediated impairment of myofibroblast differentiation is paralleled by altered activity of RhoA. (A) Primary skin fibroblasts (PSF) cultured in normoxia $\left(20 \% \mathrm{O}_{2}\right)$ treated with or without Rho inhibitor C3 transferase were stained for aSMA and F-actin. Upon C3 treatment, a reduction of aSMA-positive cells, in which aSMA colocalised with F-actin, was analysed. (B) aSMApositive PSF were quantified by counting. At least 100 cells per condition were analysed. Error bars represent mean \pm SEM, $p=\leq 0.05$. (C) RhoA activity was determined by GST-RBD pulldown experiments and immunoblotting analyses after incubating the cells in normoxia and hypoxia for the indicated time points. Hypoxia stimulated a transient increase of active RhoA (RhoA-GTP). Further hypoxic exposure leads to a decrease of RhoA activity similar to the normoxic control. Total amount of RhoA was unchanged in all conditions. Tubulin was used as a loading control.

To further investigate the role of hypoxia on RhoA activity, the cell lines L929, originated from normal subcutaneous areolar mouse tissue, and MEF were used. These cell lines feature fibroblast phenotype characteristics and were used as a cell model. Active RhoA was determined by GST-RBD pulldown experiments. In hypoxia, RhoA activity increased progressively within a period of $15 \mathrm{~min}$ up to $1 \mathrm{~h}$ in both L929 cells and MEF (Fig. 12A and B). After $4 \mathrm{~h}$ to $24 \mathrm{~h}$ of hypoxic exposure, RhoA activity declined. As expected, HIF-1a protein levels increased over time, with a strong stabilisation after $4 \mathrm{~h}$. Total RhoA protein levels did not change upon hypoxic incubation. Taken together, the analysed cell lines showed a similar RhoA activity pattern with a transient increase compared to PSF, albeit the RhoA activity in 
fibroblast cell lines peaked earlier after the onset of hypoxia. To gain further mechanistic insights into RhoA activity in hypoxia, the fibroblast (-like) cell lines L929 and MEF were used for follow-up experiments.

A

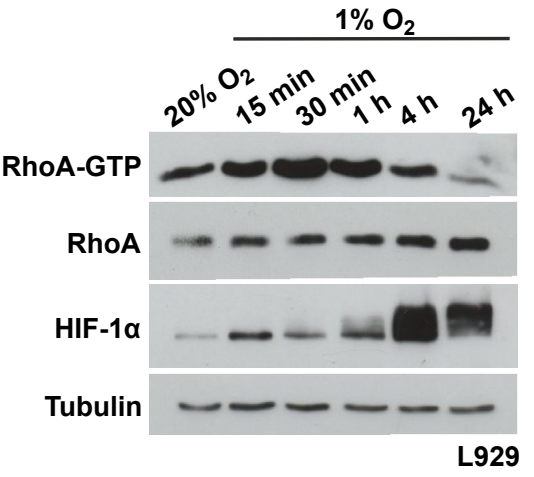

B

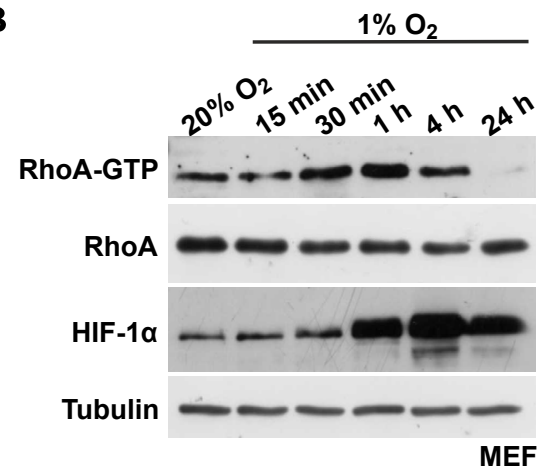

Figure 12: Dynamic changes of RhoA activity in hypoxia in L929 fibroblasts and mouse embryonic fibroblasts (MEF). Active RhoA (RhoA-GTP) was determined by GST-RBD pulldown experiments after incubation of L929 fibroblasts $(A)$ and MEF $(B)$ in normoxia $\left(20 \% \mathrm{O}_{2}\right)$ or hypoxia $\left(1 \% \mathrm{O}_{2}\right)$ for the indicated time. GST-RBD bound protein, and total cell lysates were analysed by immunoblotting with the represented antibodies. Rapid, initial increase of RhoA activity within 15 min of reduced oxygen concentration was followed by a decrease of RhoA activity after extended hypoxic incubation in both of the cell lines. HIF-1 $1 \alpha$ was stabilised and increased over time in hypoxia. Tubulin was analysed as a loading control.

\subsection{The Rho GTPase Activating Protein ArhGAP29 expression is induced in hypoxia}

Rho GTPases cycle between an active GTP and an inactive GDP bound form. This mechanism is regulated by GEFs and GAPs (refer to chapter 1.4.2)

To study the upstream regulation of RhoA activity in hypoxia, mRNA expression levels of several GAPs and GEFs were analysed by the laboratory of Prof. Katschinski (Leinhos et al., 2019). For this purpose, several GAPs (ArhGAP1, ArhGAP5, ArhGAP18, ArhGAP19, ArhGAP21, ArhGAP29, ArhGAP35, GMIP, HMHA1, OPHN1, STARD13) and GEFs (ArhGEF1, ArhGEF10, ArhGEF11, ArhGEF15, ArhGEF18, Net1, Trio) with known impact on RhoA activity were selected. The mRNA expression levels of these GAPs and GEFs were analysed in L929 fibroblasts after $24 \mathrm{~h}$ of hypoxia. Upon hypoxia, a considerable amount of GAPs (ArhGAP5, ArhGAP18, ArhGAP19, OPHN1) and GEFs (ArhGEF1, ArhGEF15, Net1, Trio) were downregulated. Yet, only two GAPs were increased significantly (ArhGAP29 and ArhGAP35). Among these two upregulated GAPs, ArhGAP29 expression levels reached the most notable increase by more than 5 -fold compared to a normoxic control. 
Furthermore, the laboratory of Prof. Katschinski analysed the ArhGAP29 expression in different cell types after $24 \mathrm{~h}$ of hypoxic incubation. Besides, in L929 fibroblasts, hypoxic induction of ArhGAP29 expression was also noted in other murine cell lines such as C2C12, MEF as well as in primary cardiac fibroblasts and primary skin fibroblasts (Leinhos et al., 2019).

\subsubsection{ArhGAP29 dynamics are transiently induced in hypoxia}

A time course experiment on mRNA expression of ArhGAP29 in L929 fibroblasts was performed by the laboratory of Prof. Katschinski (Leinhos et al., 2019). In this experiment, the mRNA expression levels of ArhGAP29 were analysed 1, 2, 4, 8, 12, 24, and $48 \mathrm{~h}$ after onset of hypoxia and compared to a normoxic control. ArhGAP29 was already induced $1 \mathrm{~h}$ after exposure to hypoxia and further increased after $4 \mathrm{~h}$ of hypoxia. After reaching the peak of hypoxic mRNA expression after $4 \mathrm{~h}$, ArhGAP29 mRNA expression decreased with prolonged hypoxic incubation ( $8 \mathrm{~h}$ to $48 \mathrm{~h}$ ). Increased protein levels of ArhGAP29 were detectable after $4 \mathrm{~h}$ onset of hypoxia and further increased over time $(8,12$ and $24 \mathrm{~h})$.

\subsection{The hypoxic induction of ArhGAP29 is HIF-1a dependent}

To test if the hypoxic induction of ArhGAP29 is linked to the HIF pathway, stable HIF-1a knockdown clones of L929 fibroblasts (Vogler et al., 2013) were analysed. The hypoxic induction of ArhGAP29 mRNA and protein levels were significantly reduced in L929 HIF-1a knockdown (Leinhos et al., 2019). I followed up these results and analysed ArhGAP29 expression in MEF derived originally from HIF-1a null (-/-) embryos (Ryan et al., 2000). Hypoxic induction of ArhGAP29 was detectable in MEF HIF-1a knockout cells (MEF -/-) on mRNA levels; however, it was significantly reduced compared to wildtype MEF (+/+) (Fig 13A). As expected, the expression of the known HIF-1 target gene PHD3 was reduced upon knockout of HIF-1a (Fig.13B). ArhGAP29 protein expression was decreased in MEF HIF-1a knockout cells compared to the wildtype control (Fig. 13C). Wildtype MEF (+/+) demonstrated a substantial increase of HIF-1 $\alpha$ protein in hypoxia, whereas this increase was absent in MEF HIF$1 \alpha$ knockout cells (MEF -/-) as expected (Fig. 13C). 

poxia in control cells, whereas in ArhGAP29 knockdown cells the RhoA activity is still increased resulting in an overall longer-lasting activation of RhoA.

A

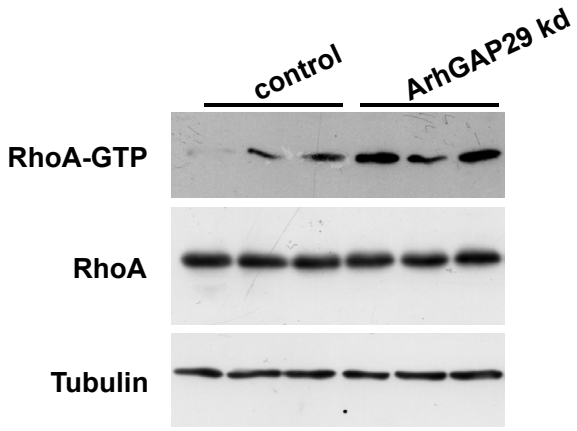

B

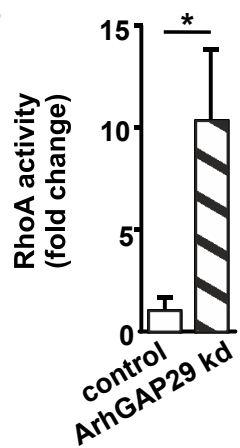

C

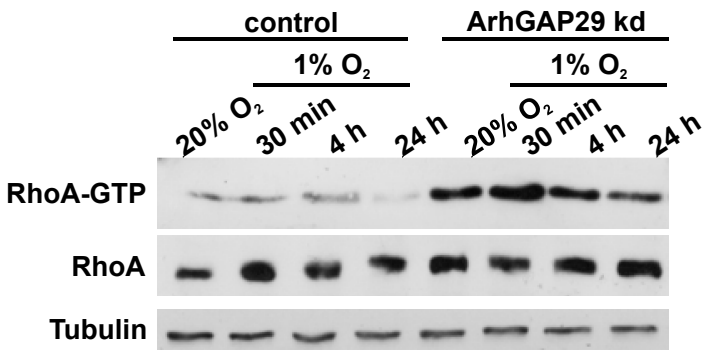

D

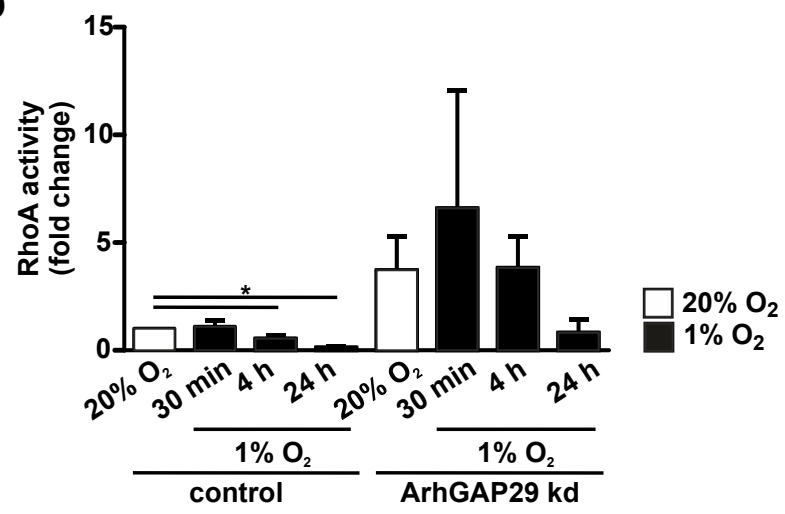

Figure 14: Knockdown of ArhGAP29 in L929 fibroblasts results in increased RhoA activity.

(A) Active RhoA (RhoA-GTP) was sedimented with GST-RBD beads from L929 control and ArhGAP29 knockdown (kd) L929 fibroblasts cultured in normoxia $\left(20 \% \mathrm{O}_{2}\right)$. Three independent pulldown experiments were performed. The samples were loaded together with the respective total cell lysates on one SDS-gel and were analysed by immunoblotting using the indicated antibodies. Tubulin was used as a loading control. RhoA activity was increased in L929 ArhGAP29 kd cells compared to L929 control cells. (B) The Immunoblot band intensities shown in A were quantified with Image J. Band intensities of active RhoA were normalised to band intensities of total RhoA. The ratio active RhoA to total RhoA is shown. (C) L929 control and ArhGAP29 kd cells were incubated in normoxia $\left(20 \% \mathrm{O}_{2}\right)$ and in hypoxia ( $1 \% \mathrm{O}_{2}$ for $30 \mathrm{~min}, 4 \mathrm{~h}$ and $24 \mathrm{~h}$ ). RhoA-GTP was sedimented in GST-RBD pulldown experiments and analysed by immunoblotting experiments together with total cell lysates with the indicated antibodies. The experiment was repeated four times; one representative experiment is shown. In the ArhGAP29 kd cells the RhoA activity in hypoxia lasted longer than in the L929 control cells. (D) Quantification of active RhoA in L929 control and ArhGAP29 kd cells of the experiment described in C. Error bars represent mean \pm SEM, $p=\leq 0.05$. 


\subsubsection{F-actin formation is changed by knockdown of ArhGAP29}

Since RhoA is involved in the organisation of the actin cytoskeleton, the effect of ArhGAP29 knockdown on F-actin structures in L929 fibroblasts was analysed. F-actin was visualised with phalloidin staining. F-actin structures were found to be more distinct in ArhGAP29 knockdown L929 fibroblasts than in control cells (Fig. 15A). Further investigation with nonbiased cluster analysis using the MiToBo application affirmed the change of F-actin structures upon knockdown of ArhGAP29 in normoxia. The F-actin cluster distribution (C1-C6) was clearly diverse in control and ArhGAP29 knockdown L929 fibroblasts (Fig. 15B), indicating that the knockdown of ArhGAP29 leads to a remodelling process of the actin cytoskeleton.

A

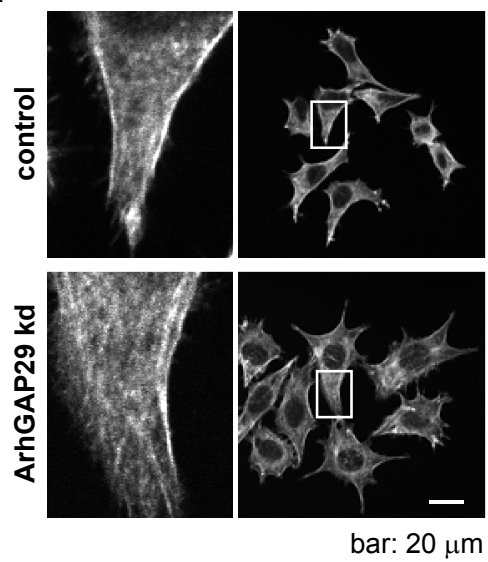

B
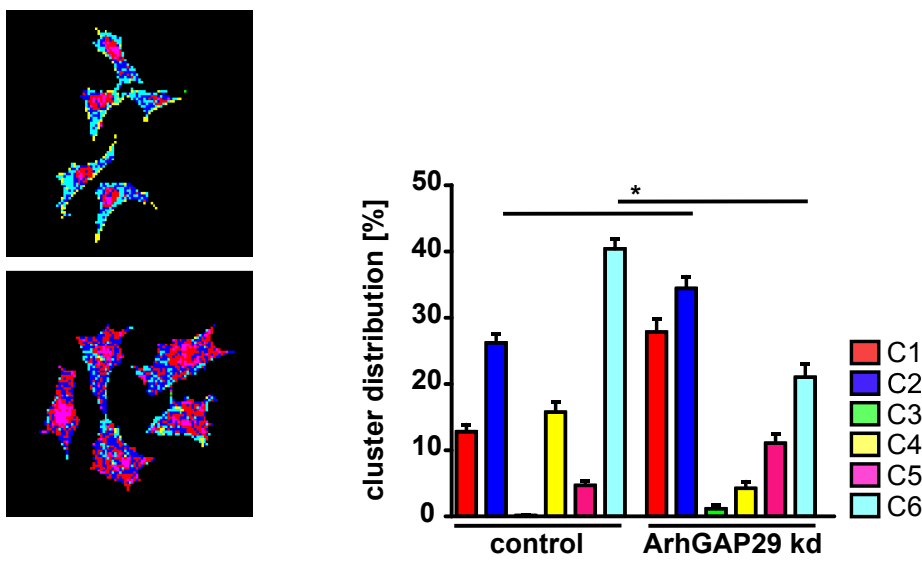

Figure 15: ArhGAP29 knockdown results in the remodelling of the actin cytoskeleton.

(A) F-actin structures were analysed by phalloidin staining of L929 control and ArhGAP29 knockdown (kd) fibroblasts in normoxia $\left(20 \% \mathrm{O}_{2}\right)$. Knockdown of ArhGAP29 resulted in increased F-actin formation. Magnification of a cell area (left panel). The area of magnification is indicated by the white boxes (middle panel). The F-actin patterns of control and ArhGAP29 kd fibroblasts were analysed with MiToBo. Highly similar structural patterns of F-actin were defined as clusters that were visualised by six colours in pseudo-coloured images (right panel). (B) Quantification of cluster (C1-C6) distribution. At least 50 cells per condition were analysed. Error bars represent mean $\pm S E M, p=\leq 0.05$. 


\subsubsection{MRTF-A localisation is altered in ArhGAP29 knockdown fibroblasts}

MRTF-A and SRF have been reported to be linked to RhoA signalling and thus to regulate the myofibroblast differentiation (Small et al., 2010; Velasquez et al., 2013). Enhanced Factin polymerisation promotes the nuclear import of MRTF-A and consequently the transcription of target genes inducing the myofibroblastic programme (Velasquez et al., 2013).

MRTF-A localisation was examined in L929 fibroblasts both in normoxia and hypoxia by immunofluorescence staining, using a specific MRTF-A antibody. In control cells, endogenous MRTF-A was localised mostly in the cytoplasm under normoxic conditions and did not show significant changes of localisation in hypoxia (Fig. 16). In contrast, endogenous MRTF-A was highly enriched in the nucleus both in normoxia and in hypoxia when ArhGAP29 was knocked down. To test, if the altered nuclear accumulation of MRTF-A was dependent on RhoA, cells were treated with the Rho inhibitor C3 transferase. Inhibition of RhoA by C3 transferase resulted in a more cytoplasmic localisation of MRTF-A in the ArhGAP29 knockdown cells. The cytoplasmic localisation of MRTF-A in ArhGAP29 knockdown cells was observed both in normoxia and in hypoxia (Fig. 16A). For quantification, the ratio of nuclear localised MRTF-A and cytoplasmic localised MRTF-A was validated (Fig. 16B). Besides endogenous MRTF-A, the localisation of exogenous GFP-tagged MTRF-A was analysed as well. The study of exogenous MRTF-A localisation showed results similar to endogenous MRTF-A. More nuclear localisation of exogenous, GFP-tagged MTRF-A was observed in ArhGAP29 knockdown cells in normoxia and hypoxia. Upon treatment with Rho inhibitor C3 transferase, exogenous nuclear MTRF-A was reduced (Fig. 16C and D). 
A
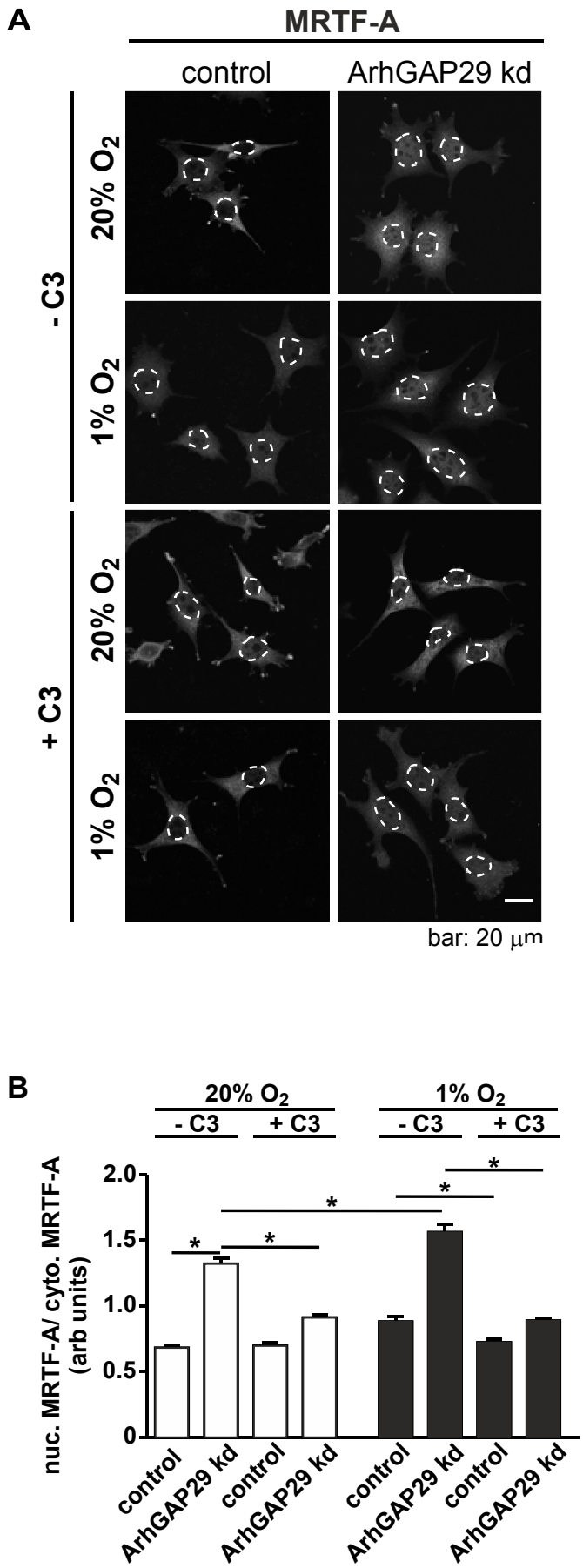

C

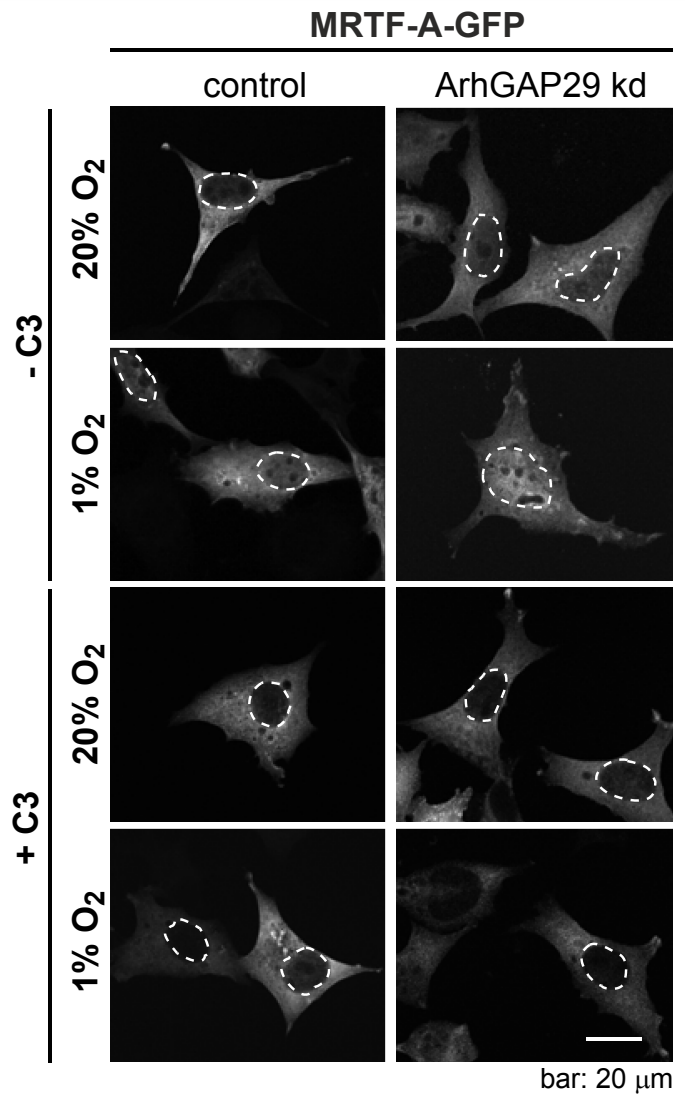

D

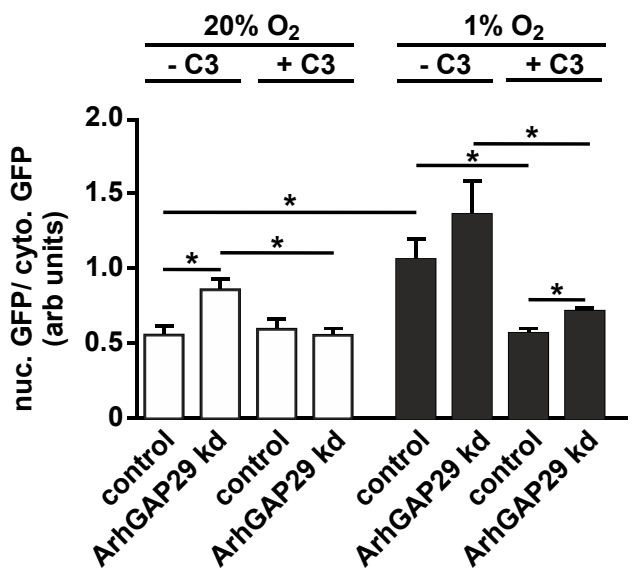

Figure 16: ArhGAP29 knockdown results in enhanced nuclear localisation of MRTF-A.

(A) Endogenous MRTF-A localisation was determined in L929 control and ArhGAP29 knockdown (kd) fibroblasts in normoxia $\left(20 \% \mathrm{O}_{2}\right)$ and hypoxia $\left(1 \% \mathrm{O}_{2}\right)$ by specific immunofluorescence staining. MRTF-A showed a stronger accumulation in ArhGAP29 kd cells. Nuclear MRTF-A accumulation was reduced upon Rho inhibitor $C 3$ treatment. (B) For quantification of the experiments performed in $A$, the ratio of nuclear MRTF-A to cytoplasmic MRTF-A was determined. (C) GFP-tagged exogenous MRTFA localisation was analysed in L929 wt, and ArhGAP29 kd cells under the conditions described in A and similar results were obtained. (D) The ratio of nuclear GFP-tagged MRTF-A to cytoplasmic GFPtagged MRTF-A of the experiments described in $C$ was determined for quantification. At least 36 cells per condition were analysed. Error bars represent mean \pm SEM, $p=\leq 0.05$. 


\subsubsection{ArhGAP29 knockdown results in altered SRE-dependent promoter activity and induction of MRTF-A/SRF target gene expression}

To further investigate the effects of ArhGAP29 on MRTF-A/SRF dependent signalling, luciferase reporter gene assays were performed in L929 fibroblasts in order to determine SRE promoter activity.

The knockdown of ArhGAP29 resulted in increased SRE-luciferase activity in normoxia and hypoxia (Fig. 17A). Furthermore, the MRTF-A/SRF target gene connective tissue growth factor (CTGF, also knowns as cellular communication network factor Ccn2) was induced significantly in ArhGAP29 knockdown L929 fibroblasts in normoxia and hypoxia compared to control fibroblasts (Fig. 17B).

A

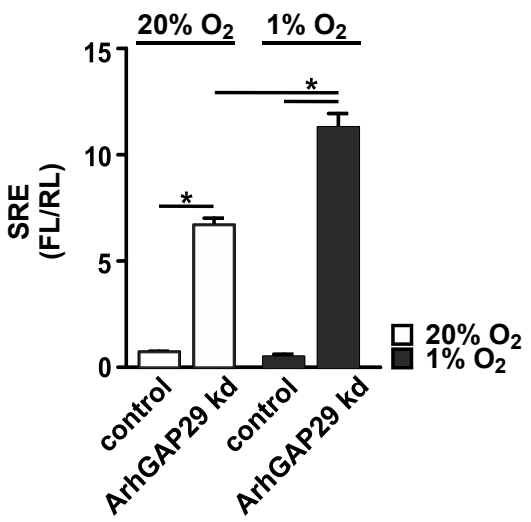

B

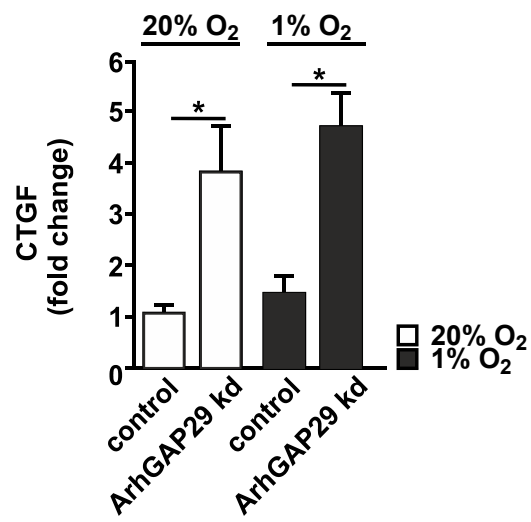

Figure 17: SRE-dependent promoter activity and induction of MRTF-A/SRF target gene expression are altered upon knockdown of ArhGAP29. (A) SRE promoter activity was determined by the ratio of SRE driven firefly luciferase $(F L)$ and renilla luciferase $(R L)$. Knockdown $(k d)$ of ArhGAP29 resulted in an increase of SRE promoter activity both in normoxia $\left(20 \% \mathrm{O}_{2}\right)$ and hypoxia $\left(1 \% \mathrm{O}_{2}\right)$. Data were compared to controls and are represented as fold change. (B) The MRTF-A/SRF target gene connective tissue growth factor (CTGF) mRNA expression was analysed by qRT-PCR. The CTGF mRNA expression levels were upregulated in ArhGAP29 kd L929 fibroblasts in normoxia and hypoxia. The mRNA expression levels were normalised to the housekeeping gene ms12 and are shown as fold change compared to the control. For each condition, at least three samples were analysed. Error bars represent mean \pm SEM, $p=\leq 0.05$. 


\subsection{The knockdown of ArhGAP29 in primary fibroblasts prevents the impairment of myofibroblast differentiation in hypoxia}

Experiments in the cell lines L929 and MEF revealed a link between the hypoxic induction of ArhGAP29 and the MRTF-A/SRF-RhoA signalling. L929 and MEF are a useful cell tool, displaying fibroblast-like characteristics; however, these cells are not capable of a transition into myofibroblasts. Therefore, to further investigate if ArhGAP29 plays a role in myofibroblast differentiation in hypoxia, a knockdown of ArhGAP29 was established in PSF.

The knockdown of ArhGAP29 via shRNA was verified by reduced mRNA expression levels of ArhGAP29 cells compared to controls (non-transduced and non-targeting shRNA control (shc), (Fig. 18A). The reduction of ArhGAP29 mRNA expression was observed in normoxia and hypoxia. The knockdown of ArhGAP29 in PSF resulted in an upregulation of aSMA in normoxia and hypoxia compared to respective controls cells. Hypoxia significantly reduced aSMA mRNA expression levels in control cells. However, this effect was decreased in ArhGAP29 knockdown PSF (Fig. 18B). In addition, immunofluorescence staining of aSMA was performed to further evaluate the impact of the knockdown of ArhGAP29 on the myofibroblast differentiation. The amount of aSMA-positive cells was reduced in hypoxia compared to normoxia in control cells (Fig.18C). However, hypoxia did not longer decrease the number of aSMA-positive cells upon knockdown of ArhGAP29 (Fig.18C). 
A

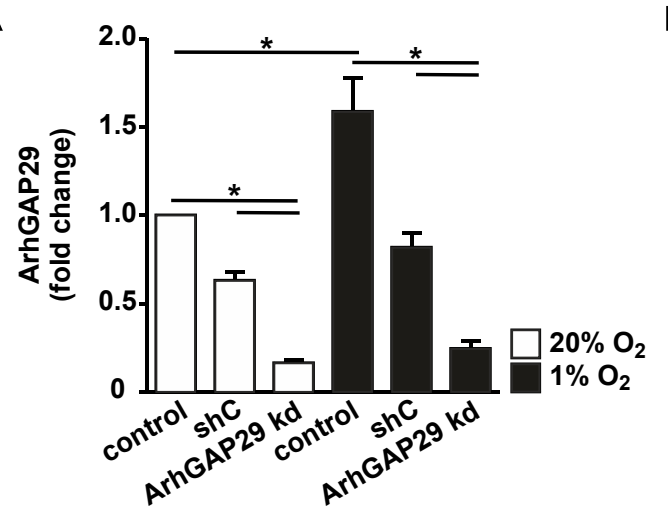

C

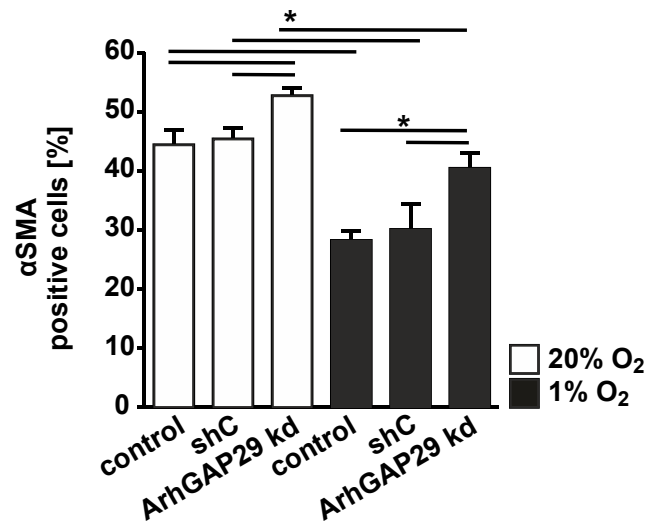

B

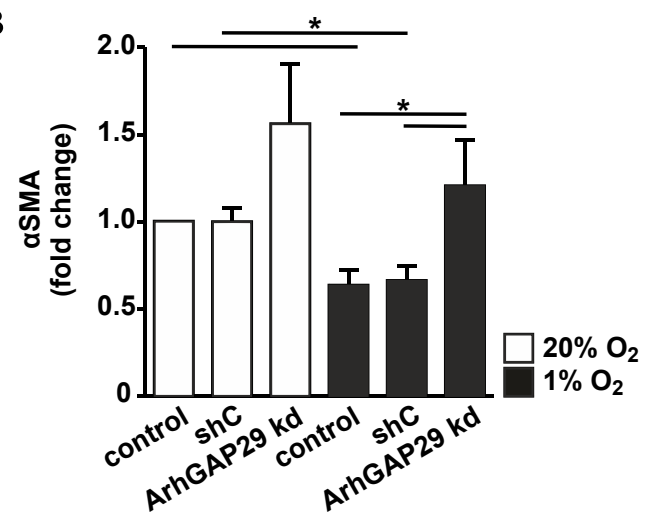

Figure 18: Knockdown of ArhGAP29 prevents the hypoxia-mediated myofibroblast dedifferentiation of primary fibroblasts. (A) Knockdown (kd) of ArhGAP29 was established in primary skin fibroblasts (PSF) and verified by qRT-PCR which showed reduced ArhGAP29 mRNA expression levels in normoxia $\left(20 \% \mathrm{O}_{2}\right)$ and hypoxia $\left(1 \% \mathrm{O}_{2}\right)$. (B) The expression of aSMA was upregulated in ArhGAP29 kd PSF. The mRNA expression levels were normalised to the housekeeping gene ms 12 and are shown as fold change compared to controls. Cells were isolated from six animals; data were pooled $n=6$.

(C) aSMA-positive cells were quantified. Kd of ArhGAP29 resulted in increased aSMA-positive cells in normoxia and hypoxia. At least 200 cells per condition were analysed. Error bars represent mean \pm SEM, $p=\leq 0.05$. 


\section{Discussion}

Myofibroblasts are crucial for normal wound and tissue repair (Hinz, 2007). Wound healing is a highly complex process, in which tissue oxygenation plays an important role. Acute hypoxia stabilises HIF-1 $\alpha$ and thus activates HIF-1 target genes restoring disrupted vascularisation and promoting tissue remodelling (Darby et al. 2014; Hong et al. 2014). Nonetheless, chronic hypoxia results in poor wound healing and finally tissue necrosis (Sen 2009). The Rho GTPase RhoA regulates stress fiber formation and is involved in myofibroblast differentiation through downstream MRTF/SRF signalling (Ni et al., 2013; Yuan et al., 2018). The regulation of RhoA activity and thus MRTF/SRF signalling in hypoxia has not been understood in detail so far.

The laboratory of Prof. Katschinski identified that the expression of ArhGAP29, a regulator of RhoA activity, is induced in hypoxia. Based on these preliminary findings, the aim of this doctoral dissertation focused on testing the hypothesis that ArhGAP29 plays an important role in regulating RhoA activity and the MRTF/SRF-mediated myofibroblast differentiation programme in hypoxia.

In this study, it was shown that the myofibroblast differentiation is impaired by hypoxia. The suppressed myofibroblast differentiation in hypoxia was accompanied by reduced aSMA expression, limited contractile forces, cytoskeletal alterations and decreased RhoA activity. ArhGAP29 was identified to play an essential role in fine-tuning RhoA activity in hypoxia and thus to regulate downstream signalling such as the MRTF/SRF pathway, the principal inducer of the myofibroblast programme and fibrotic response. Taken together, this study revealed ArhGAP29 as a novel link between the RhoA-MRTF/SRF pathway and HIFsignalling. 


\subsection{Hypoxia is a negative modulator of myofibroblast differentiation and function}

The differentiation of fibroblasts to contractile, ECM-producing myofibroblasts is essential for wound healing and tissue remodelling (Bochaton-Piallat et al., 2016). Dysregulation of myofibroblast activity leads to irreversible fibrotic diseases as well as tissue and organ malfunction (Klingberg et al., 2013). Hypoxia and HIF signalling are critically involved in tissue remodelling and normal wound healing as well as in myofibroblast-mediated diseases, such as fibrosis.

In this study, I was able to demonstrate that hypoxia has a suppressive effect on myofibroblast differentiation. The observed myofibroblast phenotype of primary fibroblasts cultured in normoxic conditions was reversed in hypoxia. Signature myofibroblast markers, such as aSMA and Tagln, were downregulated upon prolonged incubation in low oxygen concentration. The overall actin filament organisation was affected in hypoxia and aSMA was no longer intercalated in F-actin. Furthermore, hypoxic primary cells showed less ability to contract a collagen matrix, which is in line with the decreased expression of aSMA. The fibroblast to myofibroblast transition is complex and involves the orchestrated interplay of many factors and mechanisms. Mechanical stress promotes the myofibroblast differentiation. It is widely reported that substrate stiffness influences cell morphology and function, for example, rigid surfaces can promote stress fiber formation in cultured fibroblasts (Georges and Janmey, 2005; Discher et al., 2005; Solon et al., 2007). The primary fibroblasts used in this study were cultured on rigid cell culture plastic surfaces; hence, this might have promoted the observed fibroblast to myofibroblast transition in normoxia. However, exposure to hypoxia led to a regression of the observed myofibroblast phenotype indicating that mechanical stress is not enough to fully initiate the myofibroblast differentiation (Darby et al., 2014).

The myofibroblast differentiation was further enhanced by the addition of TGF- $\beta$, a known driver of this differentiation. In hypoxia, the cellular response to TGF- $\beta$ was diminished. The suppressive effect of hypoxia on TGF- $\beta$ stimulation was also described in corneal keratocyte myofibroblast differentiation (Xing and Bonanno, 2009). The described findings indicate that in addition to mechanical stress and cytokine stimulation, other molecular mechanisms are involved in the myofibroblast differentiation. Hypoxia-mediated impairment of myofibroblast differentiation in vitro, as seen in the presented project, has been described in rat subcutaneous and cardiac fibroblasts (Modarressi et al., 2010). In contrast, exposure of lung and liver fibroblasts to hypoxia resulted in increased myofibroblast differentiation, indicating that the tissue origin might be decisive for the hypoxic effect on the myofibroblast differentiation state. To understand these divergent findings, it is crucial to be aware of the variable $\mathrm{pO}_{2}$ at tissue level in vivo and carefully compare these to cell culture conditions. The physiological $\mathrm{pO}_{2}$ is widely diverse in tissue and organs and never reaches the atmospheric $\mathrm{pO}_{2}$ of ap- 
proximately $140 \mathrm{~mm} \mathrm{Hg}$ at sea level. Hence, every cell has a defined individual, origindependent normoxic state, that is characterised by the lack of initiation of the cellular hypoxic response (Sen, 2009; Carreau et al., 2011). Standard cell culture conditions rely on the $\mathrm{pO}_{2}$ of ambient air. Therefore, freshly isolated primary fibroblasts experience a dramatic increase of oxygen when first introduced to standard cell culture conditions (Sen and Roy, 2010; Modarressi et al., 2010). The excess supply of oxygen, also referred to as hyperoxia, was reported to initiate primary cardiac fibroblasts transdifferentitaion to myofibroblasts (Roy et al., 2003). However, the primary cells used in the presented experiments were cultured for at least one week at $20 \% \mathrm{O}_{2}$ before they were used for further experiments. This most likely allowed them to adjust to the normoxic cell culture conditions and reset their normoxic set point. This was suggested by their ability to stabilise HIF-1 $\alpha$ under experimental hypoxic conditions. Therefore, hyperoxia is unlikely to have triggered the observed normoxic myofibroblast differentiation.

A contribution of the Rho signalling pathway, particularly the involvement of RhoA, to the differentiation process of myofibroblasts has also been taken into consideration ( $\mathrm{Ni}$ et al., 2013; Jatho et al., 2015). The presented study supports the involvement of RhoA in myofibroblast differentiation, as cell treatment with the Rho inhibitor C3 transferase in normoxia resulted in the reduction of aSMA-positive, cell traversing stress fibers. Thus, these C3 transferase-treated normoxic cells displayed a cytoskeletal organisation similar to a hypoxic cell. Indeed, when analysing Rho activity of primary fibroblasts after prolonged hypoxic incubation, a decrease of RhoA activity, accompanied by a decrease of aSMA was found.

It has been reported that myofibroblasts are deactivated or disappear by apoptosis or regression after successful tissue repair (Desmoulière et al., 1995; Hecker et al., 2011; Kisseleva et al., 2012). The molecular events underlying myofibroblast regression have not been understood in detail yet. The results presented in this thesis imply that hypoxia promotes this regression and suggest a role of RhoA in this process.

\subsection{ArhGAP29 is a regulator of RhoA activity in hypoxia}

To investigate how RhoA activity is controlled in hypoxia, the laboratory of Prof. Katschinski analysed the expression of several GEFS and GAPs with known activity towards RhoA. ArhGAP29, a suppressor of RhoA activity, was identified by J. Peters (laboratory of Prof. Katschinski) to be expressed in an oxygen-dependent manner. As ArhGAP29 is involved in cytoskeletal organisation, ArhGAP29 expression levels need to be tightly controlled. Reduced ArhGAP29 expression results in remodelling of the actin cytoskeleton and abnormal embryonic development in mice (Xu et al., 2011; Barry et al., 2016; Paul et al., 2017). Fur- 
thermore, humans with mutant ArhGAP29 suffer from NSCL/P congenital disabilities (Leslie et al., 2012; Butali et al., 2014; Chandrasekharan and Ramanathan, 2014; Paul et al., 2017; Liu et al., 2017).

The hypoxic induction of ArhGAP29 was shown to be HIF-1a dependent. Several potential HIF-1 binding sites (HREs) exist within the ArhGAP29 promoter region; however, further analyses are needed to test if the HIF-1 binding sites are functional. To test this chromatin immunoprecipitation or electrophoretic mobility shift assays can be used. YAP, which can be induced in hypoxia, has been shown to be a regulator of ArhGAP29 expression (Dai et al., 2016; Qiao et al., 2017). Therefore, YAP could contribute to the expression of ArhGAP29 in hypoxia. In contrast to ArhGAP29, YAP induction is not mediated by HIF-1a (Dai et al., 2016). This argues against a role of YAP in the transcription of ArhGAP29 in hypoxia. In addition to its expression levels, YAP activity is controlled by its cellular localisation. YAP is active when in the nucleus, and inactive in the cytoplasm. Cytoplasmic retention of YAP results in the inhibition of transcription of target genes (Low et al., 2014; Das et al., 2016). To further investigate whether YAP plays a role in the hypoxic induction of ArhGAP29, the localisation of YAP in hypoxia needs to be analysed.

The ArhGAP29 knockdown experiments presented in this study demonstrate that ArhGAP29 regulates RhoA activity in normoxia and hypoxia in fibroblasts. Reduction of ArhGAP29 expression resulted in increased RhoA activity and increased stress fiber formation both in normoxia and in hypoxia. The RhoA kinetics were shifted in hypoxia and RhoA remained active for longer in ArhGAP29 kd cells. However, it should be noted that the knockdown of ArhGAP29 did not completely prevent the reduction of RhoA activity in hypoxia. Considering that there are more than 66 different human GAPs known it is likely that other GAPs are involved in the hypoxic regulation of RhoA (Amin et al., 2016). In addition, the possibility that the approximately 24 GEFs associated with RhoA play a role in balancing RhoA activity in hypoxia has not been excluded (Rossman et al., 2005).

It should be noted that the observed decrease of RhoA activity in hypoxia followed a prior rapid but transient increase of RhoA activity. The molecular mechanism underlying this fast increase in RhoA activity at the beginning of hypoxic incubation cannot be explained by the presented results. Throughout the literature, conflicting data about the influence of hypoxia on RhoA activity are found, and both increase and decrease of RhoA activity in hypoxia have been reported (Zieseniss, 2014). However, this study shows that RhoA activity changes over time in hypoxia, which could explain the controversial results. 


\subsection{RhoA activity and MRTF-A signalling are modulated by ArhGAP29 expression in hypoxia}

The knockdown of ArhGAP29 resulted in increased RhoA activity in line with enhanced stress fiber formation both in normoxia and in hypoxia. These cellular actin dynamics are linked to the MRTF/SRF signalling pathway (Olson and Nordheim, 2010). The nuclear import of MRTF-A, and consequently the activation of MRTF/SRF target genes, requires the RhoA mediated turnover of G-actin to F-actin (Olson and Nordheim, 2010; Small, 2012). Enhanced nuclear localisation of MRTF-A was observed in ArhGAP29 knockdown cells in normoxia and hypoxia. The nuclear accumulation of MRTF-A was reversible upon Rho inhibition. The MRTF/SRF signalling pathway is known to play an important role in regulating the myofibroblast programme (Small, 2012). Thus, the knockdown of ArhGAP29 not only had an impact on the actin cytoskeleton but also on RhoA dependent signalling.

MRTF-A deficient mice show impaired myofibroblast differentiation associated with reduced scarring after myocardial infarction, whereas the activation of the MRTF-A pathway via small molecules has been reported to be beneficial for wound healing (Small et al., 2010; Velasquez et al., 2013). Thus, targeting the MRTF-A pathway could be a promising strategy in treating fibrotic diseases associated with inappropriate myofibroblast activity.

In this dissertation, a novel link between ArhGAP29 and the RhoA-F-actin-MRTF/SRF signalling pathway in hypoxia was discovered, indicating a possible therapeutic approach for targeting myofibroblasts, specifically in hypoxic tissue. Growing evidence suggests that GAPs could be druggable targets and small molecular modulators of GAPs could be developed (Vigil et al., 2010). The pharmacological manipulation of GAPs has already been considered for cancer therapy; however, this concept requires further research (Vigil et al., 2010).

In light of the presented data, manipulating RhoA activity to prevent fibrosis indirectly by addressing the HIF pathway could provide a new potential therapeutic approach. Small molecule inhibitors of the PHD enzymes can activate HIF-signalling and have been extensively used in clinical studies in treating renal anaemia (Katschinski, 2009; Haase, 2017). When treating cells with the PHD inhibitor DMOG, the laboratory of Prof. Katschinski could show that ArhGAP29 is also affected when the HIF system is activated in normoxia. Thus, targeting RhoA signalling via PHD inhibitors could a feasible approach. 


\subsection{Conclusion and outlook}

Although myofibroblasts are crucial for normal wound healing and tissue remodelling due to their contractile function, excessive myofibroblast activity can cause pathological tissue dysfunction (Hinz, 2007). In this dissertation, a connection between the RhoA-MRTF/SRF signalling pathway and the master regulator of the hypoxic response (HIF-1) was described. The presented data highlight the important regulatory role of ArhGAP29 in fine-tuning RhoA dependent myofibroblast programme in hypoxia.

A myofibroblast phenotype accompanied by an increase of aSMA and pronounced stress fibers was observed in primary fibroblasts cultured in normoxia. In contrast, hypoxia initiated the HIF-1 1 -dependent induction of ArhGAP29, which inhibited RhoA activity and consequently MRTF/SRF signalling. Hypoxia impaired myofibroblast differentiation, as seen by reduced stress fiber formation and restricted aSMA expression. The knockdown of ArhGAP29 prevented the myofibroblast regression in hypoxia, because the knockdown increased RhoA activity and thus activated the MRTF/SRF pathway and the myofibroblast programme (Fig. 19).

The oxygenation state as a driver for fibroblast to myofibroblast differentiation is controversially discussed in the scientific community (Modarressi et al., 2010; Zhao et al., 2017). Albeit Modarressi et al. (2010) assumed a role of RhoA signalling in hypoxia-mediated suppression of myofibroblast differentiation, the underlying potential pathway was not further investigated. This study adds to the understanding of the pathway and describes a connection between hypoxia-mediated suppression of myofibroblasts and RhoA-MRTF/SRF signalling via ArhGAP29. Thus, targeting ArhGAP29 may lead to new therapeutic strategies to approach pathophysiological conditions involving myofibroblast dysfunctions, such as fibrosis or poor wound healing. The pharmacological manipulation of GAPs has already been considered for cancer therapy; however, the concept remains in an early stage of research (Vigil et al., 2010). Addressing the HIF pathway by small molecule inhibitors of the PHD enzymes seems to be a promising therapeutic approach (Katschinski, 2009). The laboratory of Prof. Katschinski was able to demonstrate induction of ArhGAP29 in normoxia after pharmacological PHD inhibition via DMOG.

Interestingly, hypoxic induction of ArhGAP29 was not limited to one cell type, and for example, it was also observed in primary cardiac fibroblasts by the laboratory of Prof. Katschinski. Regarding the important role of myofibroblasts in the remodelling response of the ischemic heart, it would be of high interest to investigate the role of ArhGAP29 in the context of cardiac tissue remodelling and scarring. Preliminary, unpublished data of Prof. Katschinski's 
laboratory allowed first evidence that ArhGAP29 protein levels were elevated in murine hearts after myocardial infarction.

Taken together, the presented data contribute to a better understanding of the complex molecular mechanisms of the RhoA-MRTF/SRF signalling axis in hypoxia and thus add insights to the highly orchestrated fibroblast to myofibroblast differentiation process. Finally, these findings may provide approaches for new therapeutic strategies targeting pathological conditions of abnormal scarring and wound healing.

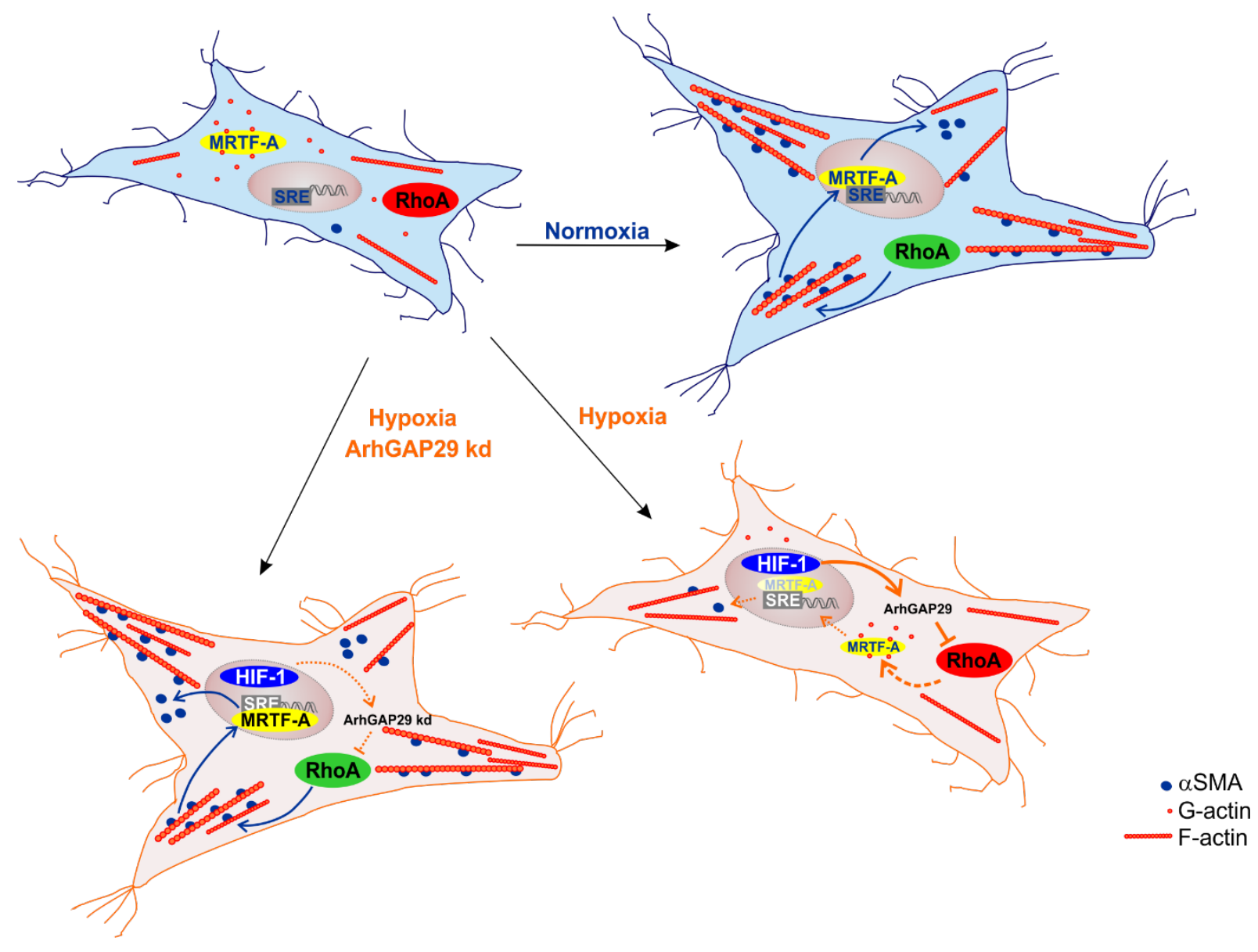

Figure 19: Illustrated summary of the role of ArhGAP29 in myofibroblast differentiation under hypoxic conditions. Cultivation of fibroblasts in normoxia $\left(20 \% \mathrm{O}_{2}\right)$ leads to the development of aSMA-positive actin filaments. Hypoxia reverts the myofibroblast phenotype observed in normoxia. HIF-1a-dependent expression of ArhGAP29 decreased RhoA activity and impaired the MRTF/SRF pathway and thus aSMA expression. The knockdown of ArhGAP29 prevents the hypoxia-mediated myofibroblast repression. 


\section{Bibliography}

Aldeiri, B., U. Roostalu, A. Albertini, J. Wong, A. Morabito, and G. Cossu. 2017. Transgelinexpressing myofibroblasts orchestrate ventral midline closure through TGF $\beta$ signalling. Development (Cambridge, England) 144(18):3336-3348. doi:10.1242/dev.152843.

Amano, M., M. Ito, K. Kimura, Y. Fukata, K. Chihara, T. Nakano, Y. Matsuura, and K. Kaibuchi. 1996. Phosphorylation and activation of myosin by Rho-associated kinase (Rhokinase). J. Biol. Chem. 271(34):20246-20249.

Amin, E., M. Jaiswal, U. Derewenda, K. Reis, K. Nouri, K. T. Koessmeier, P. Aspenström, A. V. Somlyo, R. Dvorsky, and M. R. Ahmadian. 2016. Deciphering the Molecular and Functional Basis of RHOGAP Family Proteins: A SYSTEMATIC APPROACH TOWARD SELECTIVE INACTIVATION OF RHO FAMILY PROTEINS. The Journal of biological chemistry 291(39):20353-20371. doi:10.1074/jbc.M116.736967.

Anderson, S., L. DiCesare, I. Tan, T. Leung, and N. SundarRaj. 2004. Rho-mediated assembly of stress fibers is differentially regulated in corneal fibroblasts and myofibroblasts. Experimental cell research 298(2):574-583. doi:10.1016/j.yexcr.2004.05.005.

Arber, S., F. A. Barbayannis, H. Hanser, C. Schneider, C. A. Stanyon, O. Bernard, and P. Caroni. 1998. Regulation of actin dynamics through phosphorylation of cofilin by LIMkinase. Nature 393(6687):805-809. doi:10.1038/31729.

Assinder, S. J., J.-A. L. Stanton, and P. D. Prasad. 2009. Transgelin: an actin-binding protein and tumour suppressor. The international journal of biochemistry \& cell biology 41(3):482-486. doi:10.1016/j.biocel.2008.02.011.

Barbacid, M. 1987. ras genes. Annual review of biochemistry 56:779-827. doi:10.1146/annurev.bi.56.070187.004023.

Barry, D. M., Y. Koo, P. R. Norden, L. A. Wylie, K. Xu, C. Wichaidit, D. B. Azizoglu, Y. Zheng, M. H. Cobb, G. E. Davis, and O. Cleaver. 2016. Rasip1-Mediated Rho GTPase Signaling Regulates Blood Vessel Tubulogenesis via Nonmuscle Myosin II. Circulation Research 119(7):810-826. doi:10.1161/CIRCRESAHA.116.309094.

Beier, F., and R. F. Loeser. 2010. Biology and pathology of Rho GTPase, PI-3 kinase-Akt, and MAP kinase signaling pathways in chondrocytes. Journal of cellular biochemistry 110(3):573-580. doi:10.1002/jcb.22604.

Bernard, O. 2007. Lim kinases, regulators of actin dynamics. The international journal of biochemistry \& cell biology 39(6):1071-1076. doi:10.1016/j.biocel.2006.11.011. 
Berra, E., A. Ginouvès, and J. Pouysségur. 2006. The hypoxia-inducible-factor hydroxylases bring fresh air into hypoxia signalling. EMBO reports 7(1):41-45. doi:10.1038/sj.embor.7400598.

Berra, E., D. Roux, D. E. Richard, and J. Pouysségur. 2001. Hypoxia-inducible factor-1 alpha (HIF-1 alpha) escapes $\mathrm{O}(2)$-driven proteasomal degradation irrespective of its subcellular localization: nucleus or cytoplasm. EMBO reports 2(7):615-620. doi:10.1093/emboreports/kve130.

Bishop, A. L., and A. Hall. 2000. Rho GTPases and their effector proteins. The Biochemical journal 348 Pt 2:241-255.

Bochaton-Piallat, M.-L., G. Gabbiani, and B. Hinz. 2016. The myofibroblast in wound healing and fibrosis: answered and unanswered questions. F1000Research 5. doi:10.12688/f1000research.8190.1.

Boureux, A., E. Vignal, S. Faure, and P. Fort. 2007. Evolution of the Rho family of ras-like GTPases in eukaryotes. Molecular biology and evolution 24(1):203-216. doi:10.1093/molbev/msl145.

Butali, A., P. Mossey, W. Adeyemo, M. Eshete, L. Gaines, R. Braimah, B. Aregbesola, J. Rigdon, C. Emeka, J. Olutayo, O. Ogunlewe, A. Ladeinde, F. Abate, T. Hailu, I. Mohammed, P. Gravem, M. Deribew, M. Gesses, A. Adeyemo, M. Marazita, and J. Murray. 2014. Rare functional variants in genome-wide association identified candidate genes for nonsyndromic clefts in the African population. American journal of medical genetics. Part A 164A(10):2567-2571. doi:10.1002/ajmg.a.36691.

Carlier, M. F. 1990. Actin polymerization and ATP hydrolysis. Advances in biophysics 26:5173.

Carreau, A., B. El Hafny-Rahbi, A. Matejuk, C. Grillon, and C. Kieda. 2011. Why is the partial oxygen pressure of human tissues a crucial parameter? Small molecules and hypoxia. Journal of cellular and molecular medicine 15(6):1239-1253. doi:10.1111/j.15824934.2011.01258.x.

Carthy, J. M. 2018. TGF $\beta$ signaling and the control of myofibroblast differentiation: Implications for chronic inflammatory disorders. Journal of cellular physiology 233(1):98-106. doi:10.1002/jcp.25879.

Chandrasekharan, D., and A. Ramanathan. 2014. Identification of a novel heterozygous truncation mutation in exon 1 of ARHGAP29 in an Indian subject with nonsyndromic cleft 
lip with cleft palate. European journal of dentistry 8(4):528-532. doi:10.4103/13057456.143637.

Chardin, P., P. Boquet, P. Madaule, M. R. Popoff, E. J. Rubin, and D. M. Gill. 1989. The mammalian $G$ protein rhoC is ADP-ribosylated by Clostridium botulinum exoenzyme C3 and affects actin microfilaments in Vero cells. The EMBO Journal 8(4):1087-1092.

Dai, X.-Y., L.-H. Zhuang, D.-D. Wang, T.-Y. Zhou, L.-L. Chang, R.-H. Gai, D.-F. Zhu, B. Yang, H. Zhu, and Q.-J. He. 2016. Nuclear translocation and activation of YAP by hypoxia contributes to the chemoresistance of SN38 in hepatocellular carcinoma cells. Oncotarget 7(6):6933-6947. doi:10.18632/oncotarget.6903.

Darby, I. A., and T. D. Hewitson. 2016. Hypoxia in tissue repair and fibrosis. Cell and tissue research 365(3):553-562. doi:10.1007/s00441-016-2461-3.

Darby, I. A., B. Laverdet, F. Bonté, and A. Desmoulière. 2014. Fibroblasts and myofibroblasts in wound healing. Clinical, Cosmetic and Investigational Dermatology 7:301-311. doi:10.2147/CCID.S50046.

Darby, I. A., N. Zakuan, F. Billet, and A. Desmoulière. 2016. The myofibroblast, a key cell in normal and pathological tissue repair. Cellular and molecular life sciences CMLS 73(6):1145-1157. doi:10.1007/s00018-015-2110-0.

Das, A., R. S. Fischer, D. Pan, and C. M. Waterman. 2016. YAP Nuclear Localization in the Absence of Cell-Cell Contact Is Mediated by a Filamentous Actin-dependent, Myosin IIand Phospho-YAP-independent Pathway during Extracellular Matrix Mechanosensing. The Journal of biological chemistry 291(12):6096-6110. doi:10.1074/jbc.M115.708313.

Dengler, V. L., M. Galbraith, and J. M. Espinosa. 2014. Transcriptional regulation by hypoxia inducible factors. Critical reviews in biochemistry and molecular biology 49(1):1-15. doi:10.3109/10409238.2013.838205.

Desmoulière, A., C. Chaponnier, and G. Gabbiani. 2005. Tissue repair, contraction, and the myofibroblast. Wound repair and regeneration official publication of the Wound Healing Society [and] the European Tissue Repair Society 13(1):7-12. doi:10.1111/j.10671927.2005.130102.x.

Desmoulière, A., A. Geinoz, F. Gabbiani, and G. Gabbiani. 1993. Transforming growth factor-beta 1 induces alpha-smooth muscle actin expression in granulation tissue myofibroblasts and in quiescent and growing cultured fibroblasts. The Journal of cell biology 122(1):103-111. 
Desmoulière, A., M. Redard, I. Darby, and G. Gabbiani. 1995. Apoptosis mediates the decrease in cellularity during the transition between granulation tissue and scar. The American journal of pathology 146(1):56-66.

Discher, D. E., P. Janmey, and Y.-L. Wang. 2005. Tissue cells feel and respond to the stiffness of their substrate. Science (New York, N.Y.) 310(5751):1139-1143. doi:10.1126/science.1116995.

Distler, J. H. W., A. Jüngel, M. Pileckyte, J. Zwerina, B. A. Michel, R. E. Gay, O. KowalBielecka, M. Matucci-Cerinic, G. Schett, H. H. Marti, S. Gay, and O. Distler. 2007. Hypoxia-induced increase in the production of extracellular matrix proteins in systemic sclerosis. Arthritis and rheumatism 56(12):4203-4215. doi:10.1002/art.23074.

Dolivo, D. M., S. A. Larson, and T. Dominko. 2017. FGF2-mediated attenuation of myofibroblast activation is modulated by distinct MAPK signaling pathways in human dermal fibroblasts. Journal of dermatological science 88(3):339-348. doi:10.1016/j.jdermsci.2017.08.013.

Dovas, A., and J. R. Couchman. 2005. RhoGDI: multiple functions in the regulation of Rho family GTPase activities. The Biochemical journal 390(Pt 1):1-9. doi:10.1042/BJ20050104.

Dugina, V., L. Fontao, C. Chaponnier, J. Vasiliev, and G. Gabbiani. 2001. Focal adhesion features during myofibroblastic differentiation are controlled by intracellular and extracellular factors. Journal of cell science 114(Pt 18):3285-3296.

Dunwoodie, S. L. 2009. The role of hypoxia in development of the Mammalian embryo. Developmental cell 17(6):755-773. doi:10.1016/j.devcel.2009.11.008.

Elsafadi, M., M. Manikandan, R. A. Dawud, N. M. Alajez, R. Hamam, M. Alfayez, M. Kassem, A. Aldahmash, and A. Mahmood. 2016. Transgelin is a TGF $\beta$-inducible gene that regulates osteoblastic and adipogenic differentiation of human skeletal stem cells through actin cytoskeleston organization. Cell death \& disease 7(8):e2321. doi:10.1038/cddis.2016.196.

Gabbiani, G. 2003. The myofibroblast in wound healing and fibrocontractive diseases. The Journal of pathology 200(4):500-503. doi:10.1002/path.1427.

Gabbiani, G., C. Chapponier, and I. Huttner. 1978. Cytoplasmic filaments and gap junctions in epithelial cells and myofibroblasts during wound healing. The Journal of cell biology 76(3):561-568. 
Gabbiani, G., G. B. Ryan, and G. Majne. 1971. Presence of modified fibroblasts in granulation tissue and their possible role in wound contraction. Experientia 27(5):549-550.

Garrett, M. D., A. J. Self, C. van Oers, and A. Hall. 1989. Identification of distinct cytoplasmic targets for ras/R-ras and rho regulatory proteins. J. Biol. Chem. 264(1):10-13.

Garvey, C., B. Tiep, R. Carter, M. Barnett, M. Hart, and R. Casaburi. 2012. Severe exerciseinduced hypoxemia. Respiratory care 57(7):1154-1160. doi:10.4187/respcare.01469.

Georges, P. C., and P. A. Janmey. 2005. Cell type-specific response to growth on soft materials. Journal of applied physiology (Bethesda, Md. 1985) 98(4):1547-1553. doi:10.1152/japplphysiol.01121.2004.

Goffin, J. M., P. Pittet, G. Csucs, J. W. Lussi, J.-J. Meister, and B. Hinz. 2006. Focal adhesion size controls tension-dependent recruitment of $\alpha$-smooth muscle actin to stress fibers. The Journal of cell biology 172(2):259-268. doi:10.1083/jcb.200506179.

Graham, A. M., and J. S. Presnell. 2017. Hypoxia Inducible Factor (HIF) transcription factor family expansion, diversification, divergence and selection in eukaryotes. PloS one 12(6):e0179545. doi:10.1371/journal.pone.0179545.

Haase, V. H. 2012. Renal cancer: oxygen meets metabolism. Experimental cell research 318(9):1057-1067. doi:10.1016/j.yexcr.2012.02.026.

Haase, V. H. 2017. Therapeutic targeting of the HIF oxygen-sensing pathway: Lessons learned from clinical studies. Experimental cell research 356(2):160-165. doi:10.1016/j.yexcr.2017.05.004.

Hackett, P. H., and R. C. Roach. 2001. High-altitude illness. The New England journal of medicine 345(2):107-114. doi:10.1056/NEJM200107123450206.

Hakem, A., O. Sanchez-Sweatman, A. You-Ten, G. Duncan, A. Wakeham, R. Khokha, and T. W. Mak. 2005. RhoC is dispensable for embryogenesis and tumor initiation but essential for metastasis. Genes \& development 19(17):1974-1979. doi:10.1101/gad.1310805.

Hall, A. 1998. Rho GTPases and the actin cytoskeleton. Science (New York, N.Y.) 279(5350):509-514.

Hayashi, M., M. Sakata, T. Takeda, T. Yamamoto, Y. Okamoto, K. Sawada, A. Kimura, R. Minekawa, M. Tahara, K. Tasaka, and Y. Murata. 2004. Induction of glucose transporter 1 expression through hypoxia-inducible factor 1alpha under hypoxic conditions in trophoblast-derived cells. The Journal of endocrinology 183(1):145-154. doi:10.1677/joe.1.05599. 
Heasman, S. J., and A. J. Ridley. 2008. Mammalian Rho GTPases: new insights into their functions from in vivo studies. Nature reviews. Molecular cell biology 9(9):690-701. doi:10.1038/nrm2476.

Hecker, L., R. Jagirdar, T. Jin, and V. J. Thannickal. 2011. Reversible differentiation of myofibroblasts by MyoD. Experimental cell research 317(13):1914-1921. doi:10.1016/j.yexcr.2011.03.016.

Hewitson, K. S., L. A. McNeill, M. V. Riordan, Y.-M. Tian, A. N. Bullock, R. W. Welford, J. M. Elkins, N. J. Oldham, S. Bhattacharya, J. M. Gleadle, P. J. Ratcliffe, C. W. Pugh, and C. J. Schofield. 2002. Hypoxia-inducible factor (HIF) asparagine hydroxylase is identical to factor inhibiting HIF (FIH) and is related to the cupin structural family. J. Biol. Chem. 277(29):26351-26355. doi:10.1074/jbc.C200273200.

Hill, C. S., J. Wynne, and R. Treisman. 1995. The Rho family GTPases RhoA, Rac1, and CDC42Hs regulate transcriptional activation by SRF. Cell 81(7):1159-1170.

Hinz, B. 2007. Formation and function of the myofibroblast during tissue repair. The Journal of investigative dermatology 127(3):526-537. doi:10.1038/sj.jid.5700613.

Hinz, B. 2010. The myofibroblast: paradigm for a mechanically active cell. Journal of biomechanics 43(1):146-155. doi:10.1016/j.jbiomech.2009.09.020.

Hinz, B., V. Dugina, C. Ballestrem, B. Wehrle-Haller, and C. Chaponnier. 2003. a-Smooth Muscle Actin Is Crucial for Focal Adhesion Maturation in Myofibroblast\$V. Molecular Biology of the Cell 14(6):2508-2519. doi:10.1091/mbc.E02-11-0729.

Hinz, B., and G. Gabbiani. 2003. Mechanisms of force generation and transmission by myofibroblasts. Current opinion in biotechnology 14(5):538-546.

Hinz, B., S. H. Phan, V. J. Thannickal, M. Prunotto, A. Desmoulière, J. Varga, O. de Wever, M. Mareel, and G. Gabbiani. 2012. Recent developments in myofibroblast biology: paradigms for connective tissue remodeling. The American journal of pathology 180(4):13401355. doi:10.1016/j.ajpath.2012.02.004.

Hong, W. X., M. S. Hu, M. Esquivel, G. Y. Liang, R. C. Rennert, A. McArdle, K. J. Paik, D. Duscher, G. C. Gurtner, H. P. Lorenz, and M. T. Longaker. 2014. The Role of HypoxiaInducible Factor in Wound Healing. Advances in wound care 3(5):390-399. doi:10.1089/wound.2013.0520.

Huang, L. E., J. Gu, M. Schau, and H. F. Bunn. 1998. Regulation of hypoxia-inducible factor $1 \alpha$ is mediated by an O2-dependent degradation domain via the ubiquitin-proteasome 
pathway. Proceedings of the National Academy of Sciences of the United States of America 95(14):7987-7992.

Huang, Y., J. Kapere Ochieng, M. B.-v. Kempen, A. B.-d. Munck, S. Swagemakers, W. van ljcken, F. Grosveld, D. Tibboel, and R. J. Rottier. 2013. Hypoxia inducible factor 3a plays a critical role in alveolarization and distal epithelial cell differentiation during mouse lung development. PloS one 8(2):e57695. doi:10.1371/journal.pone.0057695.

Iyer, N. V., L. E. Kotch, F. Agani, S. W. Leung, E. Laughner, R. H. Wenger, M. Gassmann, J. D. Gearhart, A. M. Lawler, A. Y. Yu, and G. L. Semenza. 1998. Cellular and developmental control of $\mathrm{O} 2$ homeostasis by hypoxia-inducible factor 1 alpha. Genes \& development 12(2):149-162.

Jaakkola, P., D. R. Mole, Y. M. Tian, M. I. Wilson, J. Gielbert, S. J. Gaskell, A. von Kriegsheim, H. F. Hebestreit, M. Mukherji, C. J. Schofield, P. H. Maxwell, C. W. Pugh, and P. J. Ratcliffe. 2001. Targeting of HIF-alpha to the von Hippel-Lindau ubiquitylation complex by O2-regulated prolyl hydroxylation. Science (New York, N.Y.) 292(5516):468-472. doi:10.1126/science.1059796.

Jackson, B., K. Peyrollier, E. Pedersen, A. Basse, R. Karlsson, Z. Wang, T. Lefever, A. M. Ochsenbein, G. Schmidt, K. Aktories, A. Stanley, F. Quondamatteo, M. Ladwein, K. Rottner, J. van Hengel, and C. Brakebusch. 2011. RhoA is dispensable for skin development, but crucial for contraction and directed migration of keratinocytes. Molecular Biology of the Cell 22(5):593-605. doi:10.1091/mbc.E09-10-0859.

Jatho, A., S. Hartmann, N. Kittana, F. Mügge, C. M. Wuertz, M. Tiburcy, W.-H. Zimmermann, D. M. Katschinski, and S. Lutz. 2015. RhoA Ambivalently Controls Prominent Myofibroblast Characteritics by Involving Distinct Signaling Routes. PloS one 10(10):e0137519. doi:10.1371/journal.pone.0137519.

Kaelin, W. G., and P. J. Ratcliffe. 2008. Oxygen sensing by metazoans: the central role of the HIF hydroxylase pathway. Molecular cell 30(4):393-402. doi:10.1016/j.molcel.2008.04.009.

Katschinski, D. M. 2009. In vivo functions of the prolyl-4-hydroxylase domain oxygen sensors: direct route to the treatment of anaemia and the protection of ischaemic tissues. Acta physiologica (Oxford, England) 195(4):407-414. doi:10.1111/j.17481716.2008.01952.x.

Kimura, K., M. Ito, M. Amano, K. Chihara, Y. Fukata, M. Nakafuku, B. Yamamori, J. Feng, T. Nakano, K. Okawa, A. Iwamatsu, and K. Kaibuchi. 1996. Regulation of myosin phos- 
phatase by Rho and Rho-associated kinase (Rho-kinase). Science (New York, N.Y.) 273(5272):245-248.

Kischer, C. W., M. R. Shetlar, and M. Chvapil. 1982. Hypertrophic scars and keloids: a review and new concept concerning their origin. Scanning electron microscopy(Pt 4):16991713.

Kisseleva, T., M. Cong, Y. Paik, D. Scholten, C. Jiang, C. Benner, K. Iwaisako, T. MooreMorris, B. Scott, H. Tsukamoto, S. M. Evans, W. Dillmann, C. K. Glass, and D. A. Brenner. 2012. Myofibroblasts revert to an inactive phenotype during regression of liver fibrosis. Proceedings of the National Academy of Sciences of the United States of America 109(24):9448-9453. doi:10.1073/pnas.1201840109.

Klingberg, F., B. Hinz, and E. S. White. 2013. The myofibroblast matrix: implications for tissue repair and fibrosis. The Journal of pathology 229(2):298-309. doi:10.1002/path.4104.

Lamarche, N., and A. Hall. 1994. GAPs for rho-related GTPases. Trends in Genetics 10(12):436-440. doi:10.1016/0168-9525(94)90114-7.

Lang, P., F. Gesbert, M. Delespine-Carmagnat, R. Stancou, M. Pouchelet, and J. Bertoglio. 1996. Protein kinase A phosphorylation of RhoA mediates the morphological and functional effects of cyclic AMP in cytotoxic lymphocytes. The EMBO Journal 15(3):510-519.

Lee, S. H., and R. Dominguez. 2010. Regulation of Actin Cytoskeleton Dynamics in Cells. Molecules and cells 29(4):311-325.

Leinhos, L., J. Peters, S. Krull, L. Helbig, M. Vogler, M. Levay, G. J. van Belle, A. J. Ridley, S. Lutz, D. M. Katschinski, and A. Zieseniss. 2019. Hypoxia suppresses myofibroblast differentiation by changing RhoA activity. Journal of cell science. doi:10.1242/jcs.223230.

Leslie, E. J., M. A. Mansilla, L. C. Biggs, K. Schuette, S. Bullard, M. Cooper, M. Dunnwald, A. C. Lidral, M. L. Marazita, T. H. Beaty, and J. C. Murray. 2012. Expression and mutation analyses implicate ARHGAP29 as the etiologic gene for the cleft lip with or without cleft palate locus identified by genome-wide association on chromosome $1 \mathrm{p} 22$. Birth defects research. Part A, Clinical and molecular teratology 94(11):934-942. doi:10.1002/bdra.23076.

Li, B., and J. H.-C. Wang. 2009. Fibroblasts and Myofibroblasts in Wound Healing: Force Generation and Measurement. Journal of tissue viability 20(4):108-120. doi:10.1016/j.jtv.2009.11.004. 
Liu, A. X., N. Rane, J. P. Liu, and G. C. Prendergast. 2001. RhoB is dispensable for mouse development, but it modifies susceptibility to tumor formation as well as cell adhesion and growth factor signaling in transformed cells. Molecular and cellular biology 21(20):69066912. doi:10.1128/MCB.21.20.6906-6912.2001.

Liu, H., T. Busch, S. Eliason, D. Anand, S. Bullard, J. J. Gowans, N. Nidey, A. Petrin, E.-A. Augustine-Akpan, I. Saadi, M. Dunnwald, S. A. Lachke, Y. Zhu, A. Adeyemo, B. Amendt, T. Roscioli, R. Cornell, J. Murray, and A. Butali. 2017. Exome sequencing provides additional evidence for the involvement of ARHGAP29 in Mendelian orofacial clefting and extends the phenotypic spectrum to isolated cleft palate. Birth defects research 109(1):2737. doi:10.1002/bdra.23596.

Low, B. C., C. Q. Pan, G. V. Shivashankar, A. Bershadsky, M. Sudol, and M. Sheetz. 2014. YAP/TAZ as mechanosensors and mechanotransducers in regulating organ size and tumor growth. FEBS letters 588(16):2663-2670. doi:10.1016/j.febslet.2014.04.012.

Madaule, P., and R. Axel. 1985. A novel ras-related gene family. Cell 41(1):31-40.

Maekawa, M., T. Ishizaki, S. Boku, N. Watanabe, A. Fujita, A. Iwamatsu, T. Obinata, K. Ohashi, K. Mizuno, and S. Narumiya. 1999. Signaling from Rho to the actin cytoskeleton through protein kinases ROCK and LIM-kinase. Science (New York, N.Y.) 285(5429):895-898.

Majno, G., G. Gabbiani, B. J. Hirschel, G. B. Ryan, and P. R. Statkov. 1971. Contraction of granulation tissue in vitro: similarity to smooth muscle. Science (New York, N.Y.) 173(3996):548-550.

McNeill, L. A., K. S. Hewitson, J. M. Gleadle, L. E. Horsfall, N. J. Oldham, P. H. Maxwell, C. W. Pugh, P. J. Ratcliffe, and C. J. Schofield. 2002. The use of dioxygen by HIF prolyl hydroxylase (PHD1). Bioorganic \& medicinal chemistry letters 12(12):1547-1550.

Meng, X.-M., D. J. Nikolic-Paterson, and H. Y. Lan. 2016. TGF- $\beta$ : the master regulator of fibrosis. Nature reviews. Nephrology 12(6):325-338. doi:10.1038/nrneph.2016.48.

Meng, Z., Y. Qiu, K. C. Lin, A. Kumar, J. K. Placone, C. Fang, K.-C. Wang, S. Lu, M. Pan, A. W. Hong, T. Moroishi, M. Luo, S. W. Plouffe, Y. Diao, Z. Ye, H. W. Park, X. Wang, F.-X. Yu, S. Chien, C.-Y. Wang, B. Ren, A. J. Engler, and K.-L. Guan. 2018. RAP2 mediates mechanoresponses of the Hippo pathway. Nature 560(7720):655-660. doi:10.1038/s41586-018-0444-0.

Michiels, C. 2004. Physiological and Pathological Responses to Hypoxia. The American journal of pathology 164(6):1875-1882. doi:10.1016/S0002-9440(10)63747-9. 
Midgley, A. C., M. Rogers, M. B. Hallett, A. Clayton, T. Bowen, A. O. Phillips, and R. Steadman. 2013. Transforming growth factor- $\beta 1$ (TGF- $\beta 1$ )-stimulated fibroblast to myofibroblast differentiation is mediated by hyaluronan (HA)-facilitated epidermal growth factor receptor (EGFR) and CD44 co-localization in lipid rafts. The Journal of biological chemistry 288(21):14824-14838. doi:10.1074/jbc.M113.451336.

Miralles, F., G. Posern, A.-I. Zaromytidou, and R. Treisman. 2003. Actin dynamics control SRF activity by regulation of its coactivator MAL. Cell 113(3):329-342.

Modarressi, A., G. Pietramaggiori, C. Godbout, E. Vigato, B. Pittet, and B. Hinz. 2010. Hypoxia impairs skin myofibroblast differentiation and function. The Journal of investigative dermatology 130(12):2818-2827. doi:10.1038/jid.2010.224.

Möller, B., M. Glaß, D. Misiak, and Posch S. 2016. MiToBo - A Toolbox for Image Processing and Analysis. Journal of Open Research Software 4(9):31. doi:10.5334/jors.103.

Musyoka, J. N., M. C. P. Liu, D. S. Pouniotis, C. S. F. Wong, D. D. Bowtell, P. J. Little, R. Getachew, A. Möller, and I. A. Darby. 2013. Siah2-deficient mice show impaired skin wound repair. Wound repair and regeneration official publication of the Wound Healing Society [and] the European Tissue Repair Society 21(3):437-447. doi:10.1111/wrr.12045.

Myagmar, B.-E., M. Umikawa, T. Asato, K. Taira, M. Oshiro, A. Hino, K. Takei, H. Uezato, and K.-i. Kariya. 2005. PARG1, a protein-tyrosine phosphatase-associated RhoGAP, as a putative Rap2 effector. Biochemical and biophysical research communications 329(3):1046-1052. doi:10.1016/j.bbrc.2005.02.069.

Myllyharju, J., and K. I. Kivirikko. 1997. Characterization of the iron- and 2-oxoglutaratebinding sites of human prolyl 4-hydroxylase. The EMBO Journal 16(6):1173-1180. doi:10.1093/emboj/16.6.1173.

Nakano, K., K. Takaishi, A. Kodama, A. Mammoto, H. Shiozaki, M. Monden, and Y. Takai. 1999. Distinct actions and cooperative roles of ROCK and mDia in Rho small G proteininduced reorganization of the actin cytoskeleton in Madin-Darby canine kidney cells. Molecular Biology of the Cell 10(8):2481-2491. doi:10.1091/mbc.10.8.2481.

Nakaya, Y., E. W. Sukowati, Y. Wu, and G. Sheng. 2008. RhoA and microtubule dynamics control cell-basement membrane interaction in EMT during gastrulation. Nature cell biology 10(7):765-775. doi:10.1038/ncb1739.

Ni, J., Z. Dong, W. Han, D. Kondrikov, and Y. Su. 2013. The role of RhoA and cytoskeleton in myofibroblast transformation in hyperoxic lung fibrosis. Free radical biology \& medicine 61:26-39. doi:10.1016/j.freeradbiomed.2013.03.012. 
Olofsson, B. 1999. Rho Guanine Dissociation Inhibitors. Cellular Signalling 11(8):545-554. doi:10.1016/S0898-6568(98)00063-1.

Olson, E. N., and A. Nordheim. 2010. Linking actin dynamics and gene transcription to drive cellular motile functions. Nature reviews. Molecular cell biology 11(5):353-365. doi:10.1038/nrm2890.

Parizi, M., E. W. Howard, and J. J. Tomasek. 2000. Regulation of LPA-promoted myofibroblast contraction: role of Rho, myosin light chain kinase, and myosin light chain phosphatase. Experimental cell research 254(2):210-220. doi:10.1006/excr.1999.4754.

Paterson, H. F., A. J. Self, M. D. Garrett, I. Just, K. Aktories, and A. Hall. 1990. Microinjection of recombinant $\mathrm{p} 21$ rho induces rapid changes in cell morphology. The Journal of cell biology 111(3):1001-1007.

Paul, B. J., K. Palmer, J. C. Sharp, C. H. Pratt, S. A. Murray, and M. Dunnwald. 2017. ARHGAP29 Mutation Is Associated with Abnormal Oral Epithelial Adhesions. Journal of dental research 96(11):1298-1305. doi:10.1177/0022034517726079.

Peng, J., L. Zhang, L. Drysdale, and G. H. Fong. 2000. The transcription factor EPAS$1 /$ hypoxia-inducible factor 2alpha plays an important role in vascular remodeling. Proceedings of the National Academy of Sciences of the United States of America 97(15):8386-8391. doi:10.1073/pnas.140087397.

Pollard, T. D. 1986. Rate constants for the reactions of ATP-and ADP-actin with the ends of actin filaments. The Journal of cell biology 103(6):2747-2754. doi:10.1083/jcb.103.6.2747.

Post, A., W. J. Pannekoek, B. Ponsioen, M. J. Vliem, and J. L. Bos. 2015. Rap1 Spatially Controls ArhGAP29 To Inhibit Rho Signaling during Endothelial Barrier Regulation. Molecular and cellular biology 35(14):2495-2502. doi:10.1128/MCB.01453-14.

Post, A., W.-J. Pannekoek, S. H. Ross, I. Verlaan, P. M. Brouwer, and J. L. Bos. 2013. Rasip1 mediates Rap1 regulation of Rho in endothelial barrier function through ArhGAP29. Proceedings of the National Academy of Sciences of the United States of America 110(28):11427-11432. doi:10.1073/pnas.1306595110.

Pugh, C. W., J. F. O'Rourke, M. Nagao, J. M. Gleadle, and P. J. Ratcliffe. 1997. Activation of hypoxia-inducible factor-1; definition of regulatory domains within the alpha subunit. $J$. Biol. Chem. 272(17):11205-11214. 
Qiao, Y., J. Chen, Y. B. Lim, M. L. Finch-Edmondson, V. P. Seshachalam, L. Qin, T. Jiang, B. C. Low, H. Singh, C. T. Lim, and M. Sudol. 2017. YAP Regulates Actin Dynamics through ARHGAP29 and Promotes Metastasis. Cell reports 19(8):1495-1502. doi:10.1016/j.celrep.2017.04.075.

Rankin, E. B., and A. J. Giaccia. 2008. The role of hypoxia-inducible factors in tumorigenesis. Cell death and differentiation 15(4):678-685. doi:10.1038/cdd.2008.21.

Ridley, A. J. 2006. Rho GTPases and actin dynamics in membrane protrusions and vesicle trafficking. Trends in cell biology 16(10):522-529. doi:10.1016/j.tcb.2006.08.006.

Riento, K., and A. J. Ridley. 2003. Rocks: multifunctional kinases in cell behaviour. Nature reviews. Molecular cell biology 4(6):446-456. doi:10.1038/nrm1128.

Rønnov-Jessen, L., and O. W. Petersen. 1996. A function for filamentous alpha-smooth muscle actin: retardation of motility in fibroblasts. The Journal of cell biology 134(1):6780.

Rossman, K. L., C. J. Der, and J. Sondek. 2005. GEF means go: turning on RHO GTPases with guanine nucleotide-exchange factors. Nature reviews. Molecular cell biology 6(2):167-180. doi:10.1038/nrm1587.

Roy, S., S. Khanna, A. A. Bickerstaff, S. V. Subramanian, M. Atalay, M. Bierl, S. Pendyala, D. Levy, N. Sharma, M. Venojarvi, A. Strauch, C. G. Orosz, and C. K. Sen. 2003. Oxygen Sensing by Primary Cardiac Fibroblasts. Circulation Research 92(3):264-271. doi:10.1161/01.RES.0000056770.30922.E6.

Ryan, H. E., J. Lo, and R. S. Johnson. 1998. HIF-1 alpha is required for solid tumor formation and embryonic vascularization. The EMBO Journal 17(11):3005-3015. doi:10.1093/emboj/17.11.3005.

Ryan, H. E., M. Poloni, W. McNulty, D. Elson, M. Gassmann, J. M. Arbeit, and R. S. Johnson. 2000. Hypoxia-inducible factor-1alpha is a positive factor in solid tumor growth. Cancer research 60(15):4010-4015.

Saras, J., P. Franzén, P. Aspenström, U. Hellman, L. J. Gonez, and C.-H. Heldin. 1997. A Novel GTPase-activating Protein for Rho Interacts with a PDZ Domain of the Proteintyrosine Phosphatase PTPL1. J. Biol. Chem. 272(39):24333-24338. doi:10.1074/jbc.272.39.24333.

Savastano, C. P., L. A. Brito, Á. C. Faria, N. Setó-Salvia, E. Peskett, C. M. Musso, L. Alvizi, S. A. M. Ezquina, C. James, GoSgene, P. Beales, M. Lees, G. E. Moore, P. Stanier, and 
M. R. Passos-Bueno. 2017. Impact of rare variants in ARHGAP29 to the etiology of oral clefts: role of loss-of-function vs missense variants. Clinical genetics 91(5):683-689. doi:10.1111/cge.12823.

Scharenberg, M. A., B. E. Pippenger, R. Sack, D. Zingg, J. Ferralli, S. Schenk, I. Martin, and R. Chiquet-Ehrismann. 2014. TGF- $\beta$-induced differentiation into myofibroblasts involves specific regulation of two MKL1 isoforms. Journal of cell science 127(Pt 5):1079-1091. doi:10.1242/jcs. 142075 .

Schofield, C. J., and P. J. Ratcliffe. 2005. Signalling hypoxia by HIF hydroxylases. Biochemical and biophysical research communications 338(1):617-626. doi:10.1016/j.bbrc.2005.08.111.

Semenza, G. L. 2009. Involvement of oxygen-sensing pathways in physiologic and pathologic erythropoiesis. Blood 114(10):2015-2019. doi:10.1182/blood-2009-05-189985.

Semenza, G. L., and G. L. Wang. 1992. A nuclear factor induced by hypoxia via de novo protein synthesis binds to the human erythropoietin gene enhancer at a site required for transcriptional activation. Molecular and cellular biology 12(12):5447-5454.

Sen, C. K. 2009. Wound healing essentials: let there be oxygen. Wound repair and regeneration official publication of the Wound Healing Society [and] the European Tissue Repair Society 17(1):1-18. doi:10.1111/j.1524-475X.2008.00436.x.

Sen, C. K., and S. Roy. 2010. Oxygenation state as a driver of myofibroblast differentiation and wound contraction: hypoxia impairs wound closure. The Journal of investigative dermatology 130(12):2701-2703. doi:10.1038/jid.2010.316.

Singer, A. J., and R. A. Clark. 1999. Cutaneous wound healing. The New England journal of medicine 341(10):738-746. doi:10.1056/NEJM199909023411006.

Small, E. M. 2012. The actin-MRTF-SRF gene regulatory axis and myofibroblast differentiation. Journal of cardiovascular translational research 5(6):794-804. doi:10.1007/s12265012-9397-0.

Small, E. M., J. E. Thatcher, L. B. Sutherland, H. Kinoshita, R. D. Gerard, J. A. Richardson, J. M. Dimaio, H. Sadek, K. Kuwahara, and E. N. Olson. 2010. Myocardin-related transcription factor-a controls myofibroblast activation and fibrosis in response to myocardial infarction. Circulation Research 107(2):294-304. doi:10.1161/CIRCRESAHA.110.223172. 
Soeno, Y., Y. Shimada, and T. Obinata. 1999. BDM (2,3-butanedione monoxime), an inhibitor of myosin-actin interaction, suppresses myofibrillogenesis in skeletal muscle cells in culture. Cell and tissue research 295(2):307-316.

Solon, J., I. Levental, K. Sengupta, P. C. Georges, and P. A. Janmey. 2007. Fibroblast adaptation and stiffness matching to soft elastic substrates. Biophysical journal 93(12):44534461. doi:10.1529/biophysj.106.101386.

Spanakis, S. G., S. Petridou, and S. K. Masur. 1998. Functional gap junctions in corneal fibroblasts and myofibroblasts. Investigative ophthalmology \& visual science 39(8):13201328.

Stempien-Otero, A., D.-H. Kim, and J. Davis. 2016. Molecular Networks Underlying Myofibroblast Fate and Fibrosis. Journal of molecular and cellular cardiology 97:153-161. doi:10.1016/j.yjmcc.2016.05.002.

Tcherkezian, J., and N. Lamarche-Vane. 2007. Current knowledge of the large RhoGAP family of proteins. Biology of the cell 99(2):67-86. doi:10.1042/BC20060086.

Tian, H., R. E. Hammer, A. M. Matsumoto, D. W. Russell, and S. L. McKnight. 1998. The hypoxia-responsive transcription factor EPAS1 is essential for catecholamine homeostasis and protection against heart failure during embryonic development. Genes \& development 12(21):3320-3324.

Tomasek, J. J., G. Gabbiani, B. Hinz, C. Chaponnier, and R. A. Brown. 2002. Myofibroblasts and mechano-regulation of connective tissue remodelling. Nature reviews. Molecular cell biology 3(5):349-363. doi:10.1038/nrm809.

Valencia, A., P. Chardin, A. Wittinghofer, and C. Sander. 1991. The ras protein family: evolutionary tree and role of conserved amino acids. Biochemistry 30(19):4637-4648. doi:10.1021/bi00233a001.

van Buul, J. D., D. Geerts, and S. Huveneers. 2014. Rho GAPs and GEFs. Cell Adhesion \& Migration 8(2):108-124. doi:10.4161/cam.27599.

Vega, F. M., and A. J. Ridley. 2007. SnapShot: Rho family GTPases. Cell 129(7):1430. doi:10.1016/j.cell.2007.06.021.

Vega, F. M., and A. J. Ridley. 2008. Rho GTPases in cancer cell biology. FEBS letters 582(14):2093-2101. doi:10.1016/j.febslet.2008.04.039.

Vega, F. M., and A. J. Ridley. 2018. The RhoB small GTPase in physiology and disease. Small GTPases 9(5):384-393. doi:10.1080/21541248.2016.1253528. 
Velasquez, L. S., L. B. Sutherland, Z. Liu, F. Grinnell, K. E. Kamm, J. W. Schneider, E. N. Olson, and E. M. Small. 2013. Activation of MRTF-A-dependent gene expression with a small molecule promotes myofibroblast differentiation and wound healing. Proceedings of the National Academy of Sciences of the United States of America 110(42):1685016855. doi:10.1073/pnas.1316764110.

Vigil, D., J. Cherfils, K. L. Rossman, and C. J. Der. 2010. Ras superfamily GEFs and GAPs: validated and tractable targets for cancer therapy? Nature reviews. Cancer 10(12):842857. doi:10.1038/nrc2960.

Villalonga, P., and A. J. Ridley. 2006. Rho GTPases and cell cycle control. Growth factors (Chur, Switzerland) 24(3):159-164.

Vogler, M., S. Vogel, S. Krull, K. Farhat, P. Leisering, S. Lutz, C. M. Wuertz, D. M. Katschinski, and A. Zieseniss. 2013. Hypoxia modulates fibroblastic architecture, adhesion and migration: a role for HIF-1 1 in cofilin regulation and cytoplasmic actin distribution. PloS one 8(7):e69128. doi:10.1371/journal.pone.0069128.

Wang, F., P. Herzmark, O. D. Weiner, S. Srinivasan, G. Servant, and H. R. Bourne. 2002. Lipid products of $\mathrm{PI}(3) \mathrm{Ks}$ maintain persistent cell polarity and directed motility in neutrophils. Nature cell biology 4(7):513-518. doi:10.1038/ncb810.

Wang, G. L., B. H. Jiang, E. A. Rue, and G. L. Semenza. 1995. Hypoxia-inducible factor 1 is a basic-helix-loop-helix-PAS heterodimer regulated by cellular $\mathrm{O} 2$ tension. Proceedings of the National Academy of Sciences of the United States of America 92(12):5510-5514.

Wang, G. L., and G. L. Semenza. 1995. Purification and characterization of hypoxia-inducible factor 1. J. Biol. Chem. 270(3):1230-1237.

Weidemann, A., and R. S. Johnson. 2008. Biology of HIF-1alpha. Cell death and differentiation 15(4):621-627. doi:10.1038/cdd.2008.12.

Wennerberg, K., and C. J. Der. 2004. Rho-family GTPases: it's not only Rac and Rho (and I like it). Journal of cell science 117(Pt 8):1301-1312. doi:10.1242/jcs.01118.

Wheeler, A. P., and A. J. Ridley. 2004. Why three Rho proteins? RhoA, RhoB, RhoC, and cell motility. Experimental cell research 301(1):43-49. doi:10.1016/j.yexcr.2004.08.012.

Willems, I. E., M. G. Havenith, J. G. de Mey, and M. J. Daemen. 1994. The alpha-smooth muscle actin-positive cells in healing human myocardial scars. The American journal of pathology 145(4):868-875. 
Wipff, J., P. Dieude, J. Avouac, K. Tiev, E. Hachulla, B. Granel, E. Diot, J. Sibilia, L. Mouthon, O. Meyer, A. Kahan, C. Boileau, and Y. Allanore. 2009. Association of hypoxiainducible factor 1A (HIF1A) gene polymorphisms with systemic sclerosis in a French European Caucasian population. Scandinavian journal of rheumatology 38(4):291-294. doi:10.1080/03009740802629432.

Xing, D., and J. A. Bonanno. 2009. Hypoxia reduces TGFbeta1-induced corneal keratocyte myofibroblast transformation. Molecular vision 15:1827-1834.

Xu, K., A. Sacharidou, S. Fu, D. C. Chong, B. Skaug, Z. J. Chen, G. E. Davis, and O. Cleaver. 2011. Blood vessel tubulogenesis requires Rasip1 regulation of GTPase signaling. Developmental cell 20(4):526-539. doi:10.1016/j.devcel.2011.02.010.

Xu, Q., H. Duan, L. Gan, X. Liu, F. Chen, X. Shen, Y.-Q. Tang, and S. Wang. 2017. MicroRNA-1291 promotes endometrial fibrosis by regulating the ArhGAP29-RhoA/ROCK1 signaling pathway in a murine model. Molecular medicine reports 16(4):4501-4510. doi:10.3892/mmr.2017.7210.

Yu, H., M. Königshoff, A. Jayachandran, D. Handley, W. Seeger, N. Kaminski, and O. Eickelberg. 2008. Transgelin is a direct target of TGF-beta/Smad3-dependent epithelial cell migration in lung fibrosis. FASEB journal official publication of the Federation of American Societies for Experimental Biology 22(6):1778-1789. doi:10.1096/fj.07-083857.

Yuan, Y., M. Li, C. H. To, T. C. Lam, P. Wang, Y. Yu, Q. Chen, X. Hu, and B. Ke. 2018. The Role of the RhoA/ROCK Signaling Pathway in Mechanical Strain-Induced Scleral Myofibroblast Differentiation. Investigative ophthalmology \& visual science 59(8):3619-3629. doi:10.1167/iovs.17-23580.

Zhang, Q., Y. Wu, D. K. Ann, D. V. Messadi, T.-L. Tuan, A. P. Kelly, C. N. Bertolami, and A. D. Le. 2003. Mechanisms of hypoxic regulation of plasminogen activator inhibitor-1 gene expression in keloid fibroblasts. The Journal of investigative dermatology 121(5):10051012. doi:10.1046/j.1523-1747.2003.12564.x.

Zhang, Y. E. 2009. Non-Smad pathways in TGF-beta signaling. Cell research 19(1):128139. doi:10.1038/cr.2008.328.

Zhao, B., H. Guan, J.-Q. Liu, Z. Zheng, Q. Zhou, J. Zhang, L.-L. Su, and D.-H. Hu. 2017. Hypoxia drives the transition of human dermal fibroblasts to a myofibroblast-like phenotype via the TGF- $\beta 1 /$ Smad3 pathway. International journal of molecular medicine 39(1):153-159. doi:10.3892/ijmm.2016.2816. 
Zhou, X., and Y. Zheng. 2013. Cell type-specific signaling function of RhoA GTPase: lessons from mouse gene targeting. The Journal of biological chemistry 288(51):36179-36188. doi:10.1074/jbc.R113.515486.

Zieseniss, A. 2014. Hypoxia and the modulation of the actin cytoskeleton - emerging interrelations. Hypoxia (Auckland, N.Z.) 2:11-21. doi:10.2147/HP.S53575. 


\section{Acknowledgments}

The presented doctoral thesis, as well as my personal growth during the past three years, would not have been possible without the support, dedication of time, patience, and pure generosity from of the following people.

First and foremost, I would like to thank Prof. Dörthe Katschinski for her continuous scientific guidance and support, and for providing me with the opportunity to carry out my PhD in an ambitious and intellectually stimulating environment.

I dedicate my sincerest gratitude to Dr. Anke Zieseniss for the excellent supervision and guidance throughout my PhD. In addition, thank you very much for your helpful remarks during the writing process of this thesis.

I am thankful for the valuable scientific advice and support of my thesis committee members, Prof. Susanne Lutz and Prof. Ralph Kehlenbach, which helped to advance my doctoral project.

Moreover, many thanks to Prof. Frauke Alves, Prof. Ralf Dressel and Prof. Meinecke, who kindly agreed to be members of my examination committee.

I would like to thank Prof. Anne Ridley for giving me the opportunity to join her laboratory at the Randall Centre of Cell and Molecular Biophysics, King's College London. I greatly benefited from this international collaboration and your guidance. Special thanks to Dr. Ritu Garg for the training on Rho-GST pulldown assays, your trust and all your kind and supportive words. Thanks to all current and former members of the Ridley group, for making me feel welcome in your lab and making this wonderful experience memorable!

Thank you to all current and former members of the Institute of Cardiovascular Physiology, who made this working environment inviting, enjoyable and truly exceptional. Many thanks especially to $\mathrm{Dr}$ Aline Jatho and Maithily Nanadikar for helping out with animals and to Annette Hillemann, Katja Brechtel-Curth and Sören Petzke for providing countless "Mausetaxi" services. Thank you Annette and Maithily for my "apple club" membership and for jollying me along. Furthermore, I would like to express my gratitude to Sabine Krull for her excellent technical support and for always being there for advice regarding work and beyond.

I would also like to give appreciation for the privilege of participating in the International Research Training Group (IRTG) 1816, generously funded by the German Research Foundation (Deutsche Forschungsgemeinschaft, DFG), which provided the platform to perform my research. I appreciate the outstanding administrative support of IRTG 1816 academic coordination team Christina Würtz, Fulya Ören and Ulrike Fischer. 
For the entire duration of my $\mathrm{PhD}$, I have been fortunate to be surrounded by fellow IRTG 1816 students - thank you for the chance to take this journey together and for all the good memories we made!

Most of all, I am grateful for the inspiring, encouraging and supportive people who are not listed here - because you already know and there are no words to express what you have done for me in the past years and counting! 